SANDIA REPORT

SAND94-2686 - UC-900

Unlimited Release

Printed April 1995
RECEIVEN

JUN 191995

Historical and Projected Costs of
Natural Disasters

Dennis Engi

Prepared by

Sandia National Laboratories

Albuquerque, New Mexico 87185 and Livermore, California 94550

for the United States Department of Energy

under Contract DE-AC04-94AL85000

Approved for public release; distribution is unlimited. 
Issued by Sandia National Laboratories, operated for the United States Department of Energy by Sandia Corporation.

NOTICE: This report was prepared as an account of work sponsored by an agency of the United States Government. Neither the United States Government nor any agency thereof, nor any of their employees, nor any of their contractors, subcontractors, or their employees, makes any warranty, express or implied, or assumes any legal liability or responsibility for the accuracy, completeness, or usefulness of any information, apparatus, product, or process disclosed, or represents that its use would not infringe privately owned rights. Reference herein to any specific commercial product, process, or service by trade name, trademark, manufacturer, or otherwise, does not necessarily constitute or imply its endorsement, recommendation, or favoring by the United States Government, any agency thereof or any of their contractors or subcontractors. The views and opinions expressed herein do not necessarily state or reflect those of the United States Government, any agency thereof or any of their contractors.

Printed in the United States of America. This report has been reproduced directly from the best available copy.

Available to DOE and DOE contractors from

Office of Scientific and Technical Information

PO Box 62

Oak Ridge, TN 37831

Prices available from (615) 576-8401, FTS 626-8401

Available to the public from

National Technical Information Service

US Department of Commerce

5285 Port Royal Rd

Springfield, VA 22161

NTIS price codes

Printed copy: A04

Microfiche copy: A01 


\section{DISCLAIMER}

Portions of this document may be illegible in electronic image products. Images are produced from the best available original document. 
SAND94-2686

Unlimited Release

Printed April 1995
Distribution

Category UC $\longrightarrow 900$

\title{
Historical and Projected Costs of Natural Disasters
}

\author{
Dennis Engi \\ Energy and Environment Sector \\ Sandia National Laboratories \\ Albuquerque, NM
}

\begin{abstract}
Natural disasters cause billions of dollars of damage and thousands of deaths globally each year. While the magnitude is clear, the exact costs (in damage and fatalities) are difficult to clearly identify. This document reports on the results of a survey of data on the costs associated with significant natural disasters. There is an impressive amount of work and effort going into natural disaster research, mitigation, and relief. However, despite this effort, there are surprisingly few consistent and reliable data available regarding the effects of natural disasters. Even lacking consistent and complete data, it is clear that the damage and fatalities from natural disasters are increasing, both in the United States, and globally. Projections using the available data suggest that, in the United States alone, the costs of natural disasters between 1995 and 2010 will be in the range of $\$ 90$ billion ( $94 \$$ ) and 5000 lives.
\end{abstract}


THIS PAGE INTENTIONALLY LEFT BLANK 


\section{CONTENTS}

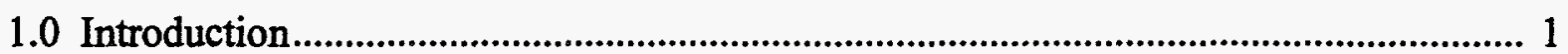

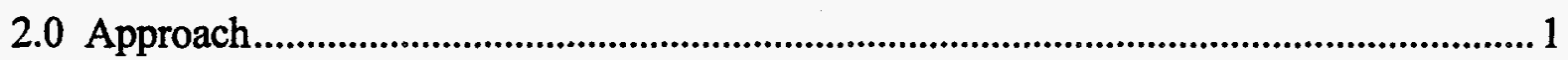

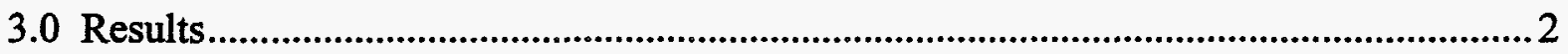

3.1 Data Deficiencies and Analysis Problems ...................................................................

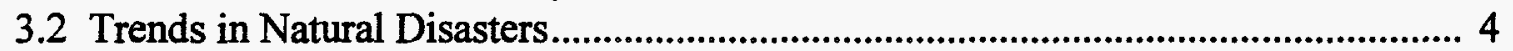

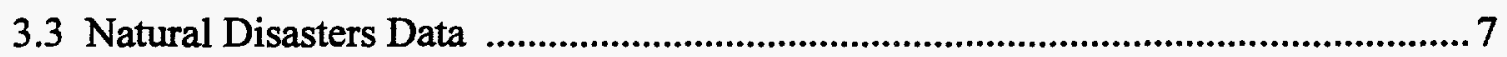

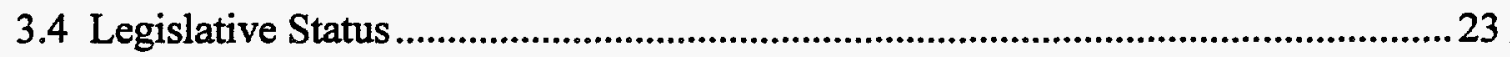

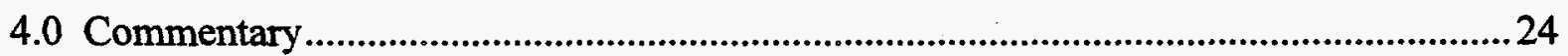

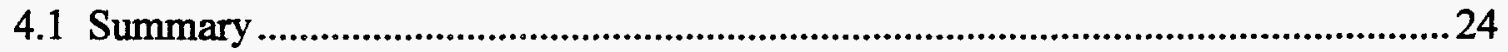

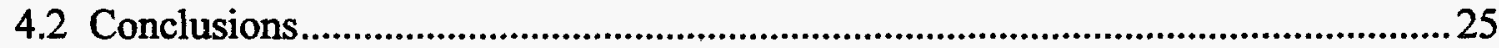

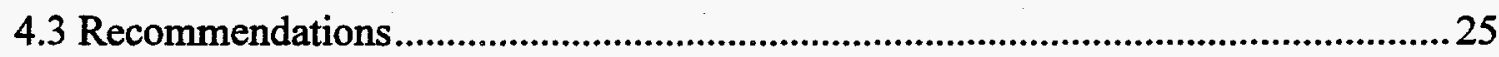

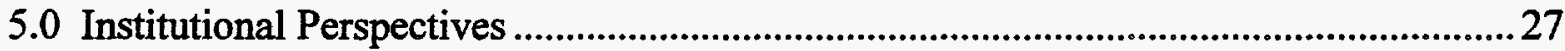

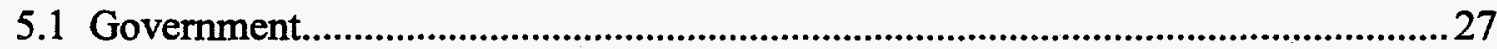

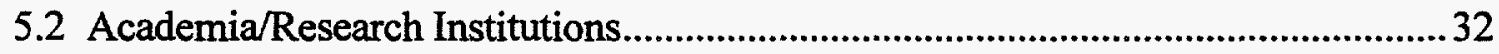

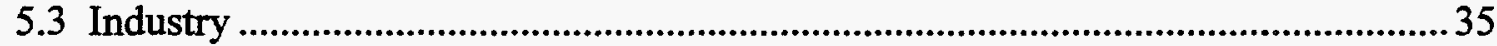

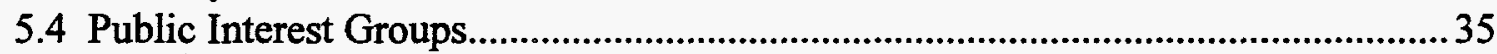

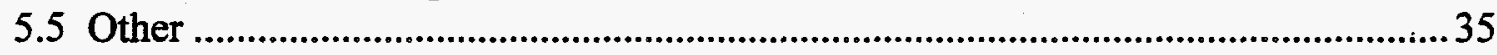

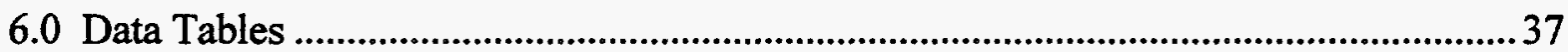

7.0 The Renewal Reward Process Model Tested ................................................................47

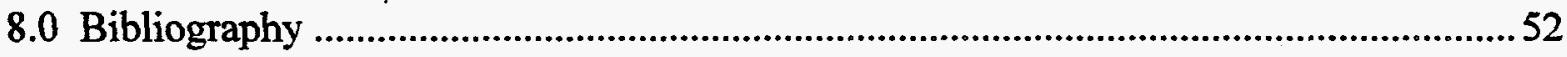

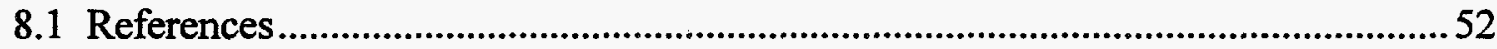

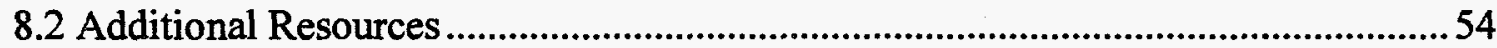

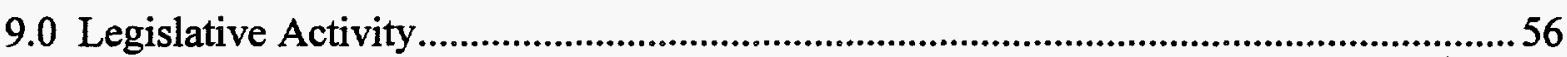


THIS PAGE INTENTIONALLY LEFT BLANK 


\section{Historical and Projected Costs of Natural Disasters}

\subsection{Introduction}

This report contains the results of a survey of data on the effects (fatalities and damage) associated with significant natural disasters in the United States. While there is an impressive amount of work and effort going into natural disaster research, mitigation, and relief, ${ }^{1}$ there are surprisingly few consistent and reliable data available regarding the effects. Available data tend to be on the fatalities (costs to society) and, to a lesser extent, the damage (economic costs) associated with the natural disasters that have occurred. There are even fewer data available regarding other effects (for example, injuries) of natural disasters. Therefore, this report focuses on fatalities and damage. The data were used to project preliminary estimates of future losses that are due to natural disasters.

\subsection{Approach}

The data gathered for this report originally focused on fatalities and damage arising from floods, droughts, tornadoes, hurricanes and typhoons, tsunamis, earthquakes, volcanic eruptions, epidemics, and famines in the United States during the past $\mathbf{3 0}$ years. However, given the lack of available data on several of these disasters, the focus changed to floods, tornadoes, hurricanes, earthquakes, and storms. No attempt was made to verify the data or to reconcile the differences that existed among data sources.

Projections of expected costs and deaths from natural disasters through the year 2010 were made using the renewal reward process. ${ }^{2}$ This model focused on the total "reward" (costs or fatalities) $\mathrm{Z}(\mathrm{t})$, accumulated by time $t$. The mean and variance of the renewal reward process are given by

$$
\mathrm{E}[\mathrm{Z}(\mathrm{t})]=\text { at, and } \operatorname{Var}[\mathrm{Z}(\mathrm{t})]=\mathrm{ct} \text {, }
$$

\footnotetext{
${ }^{1}$ See Section 5.0 for a partial listing of the various organizations involved in disaster research, mitigation, or relief.

${ }^{2}$ For more information on the renewal reward process, see the following sources:

M. Brown and H. Solomon, "A Second-Order Approximation for the Variance of a Renewal Reward Process," Stochastic Processes and their Application Vol. 3, 1975, pp. 301-314;

D.R. Cox. Renewal Theory. London: Methuen, 1962; and

W.L. Smith. "Regenerative Stochastic Processes." In Proc. Roy. Soc., A-232, 1955, pp. 6-31.
} 
where $a$ and $c$ are constants that are determined by the distributions of $X$ (time intervals between disasters) and $\mathrm{Y}$ (costs or fatalities). The formulas for $\mathrm{a}$ and $\mathrm{c}$ are

$$
a=\lambda_{1} / \mu_{1} \text {, and } c=\left(\mu_{2} \lambda_{1}{ }^{2 / \mu_{1}}{ }^{3}\right)-\left(2 n_{11} \lambda_{1} / \mu_{1}^{2}\right)+\left(\lambda_{2} / \mu_{1}\right)
$$

where

$$
\begin{aligned}
& \mu_{1}=E(t)=\text { average time between disasters } \\
& \lambda_{1}=E(\text { deaths or } D) \text { or } E(\text { costs or } \$) \\
& \mu_{2}=E\left(t^{2}\right) \\
& \lambda_{2}=E\left(D^{2}\right) \text { or } E\left(\$^{2}\right) \\
& \text { and } n_{11}=\mu_{1} \lambda_{1} \text { since } t \text { is independent of both } D \text { and } \$
\end{aligned}
$$

The projections in the body of the report are based on the data available until 1994, as described in Section 3.3 and shown in the data tables in Section 6.0. The projections begin in 1995 and indicate the expected deaths (D) or damage (\$) in the following oneyear intervals to 2010. Values for expected effects have been rounded. The first interval for which there is an expected effect is the interval between 1995 and 1996, and that effect is shown as of the beginning of 1996.

The model was tested using a subset of the actual data up to 1984, and the projections were then compared with the actual deaths and damage data available for 1984 to 1994 . See Section 7.0 for more details and the charts resulting from this test. The test suggests that the model is a reasonable (if lower-bound for damage and upper-bound for deaths) method of projecting the effects of natural disasters.

As a parallel and separate activity to gathering data on the effects of natural disasters, a survey was conducted of legislative action regarding natural disasters.

\subsection{Results}

This brief survey clearly indicates that the available data on losses (fatalities and damage) due to natural disasters are poor and that comparisons, whether from year to year or between disaster types (i.e., hurricanes versus tornadoes), must be made with caution. Nonetheless, the data do suggest that losses from natural hazards are increasing dramatically. Further, while the potential impacts of natural disasters in the United States may well be different from the impacts on a global level, specific natural disasters can be identified that appear to have great potential impact in loss of life or property, both in the United States and globally. These natural disasters-hurricanes, tornadoes, storms other than hurricanes and tornadoes, floods, and earthquakes - became the focus of data gathering. Finally, a review of the current congressional activity related to natural disasters indicates a significant level of interest and concern about the federal government's preparation for and response to major natural disasters. 


\subsection{Data Deficiencies and Analysis Problems}

While there is much information about natural disasters, there appear to be few data that have been collected in a systematic or consistent fashion. This conclusion was confirmed in telephone calls to people working in this area, as well as in the literature. For example:

The variances in or lack of available data were critical factors which hampered attempts to make viable rankings of threats by region, (FEMA, 1992, p. v).

Notwithstanding frequent appeals for improvement in the accuracy and coverage of estimates of losses suffered from extreme natural events, the quality of these data has not changed as rapidly as the number of organizations and programs directed at coping with the widely rising toll of losses, (Burton et al, 1993, p. 9).

Two sources interviewed for this report indicated that official data on losses are taken from newspaper accounts. Obvious problems with using newspapers for a major, or only, source of damage data include that the accuracy of the data is heavily dependent on who is interviewed and when they are interviewed. At the very least, given the acute sensitivity of news media to time, data from this source are more likely to be representative than complete. An additional two sources noted that different organizations only collect data for which they are responsible. For example, the Federal Emergency Management Agency (FEMA) only collects data on the dollars they supply for any given presidentially declared emergency.

The two characteristics for which natural disaster data are most frequently collected are fatalities and damage. However, even this information is inconsistently collected, is not consistent across sources for the same event(s), or is simply not available through time across natural disaster types. It is clear that no central source of data on natural disasters exists, and that comparability across data sources is severely hampered because each source has collected data using different time frames, different definitions, and different thresholds for inclusion.

Further, information about damage is extremely inconsistent across sources, and without going back to original source documents - often newspapers-it is impossible to determine exactly what each estimate of damage includes. One source states that, "a published statement that an earthquake or a coastal hurricane 'has caused property losses of X dollars' may differ from the true figure by a factor of two or three, and for a given area or type of event may not be comparable with an estimate for other areas or events," (Burton et al, 1993, p. 9).

The difficulty in assessing damage is evidenced both by the lack of such data, as shown in the data tables in Section 6.0, as well as by the wide range of estimated damage given in different sources for the same event. For example, the four largest hurricanes in the last 
25 years, and hence the most reported-on hurricanes, have damage reported in the following ranges:

Andrew (1992) 5 sources, 4 different damage estimates ranging from $\$ 5 \mathrm{~B}$ to $\$ 30 \mathrm{~B}$ Hugo (1989) 6 sources, 6 different damage estimates ranging from $\$ 4.5 \mathrm{~B}$ to $\$ 10 \mathrm{~B}$ Agnes (1972) 6 sources, 5 different damage estimates ranging from $\$ 3.5 \mathrm{~B}$ to $\$ 8 \mathrm{~B}$ Camille (1969) 4 sources, 3 different damage estimates ranging from $\$ 1.3 \mathrm{~B}$ to $\$ 5.2 \mathrm{~B}$

Estimates for fatalities are more consistent across sources of information, and are more readily available than are estimates for damage. However, even here, the estimates vary. For example, the Army Corps of Engineers put the total number of fatalities from tornadoes in 1992 at 11, while the National Weather Service's National Climatic Data Center put the total tornado deaths for just November of 1992 at 26.

Some sources do include information on "injuries" as a characteristic of natural disasters; however, this information is spotty and inconsistent. Resources for the Future recently completed a study sponsored by the National Science Foundation that involved an intensive review of all major news sources for 75 days to identify the effects of all natural disasters and major accidents reported in major news sources worldwide, (Glickman and Terry, 1994). The protocol for the review identified about 20 different items on which to search for information, items such as number of homes lost and number of people evacuated. Unfortunately, actual reporting of information on many of these items was rare.

\subsection{Trends in Natural Disasters}

Several sources noted that the discrete nature of threatening events and marked short-term and multiyear fluctuations make overall trend analysis an uncertain business. Even with this disclaimer, the literature is consistent in describing increasing loss of property and lives from natural disasters, particularly property damage in the developed world and fatalities in the less developed countries. Some examples:

In recent decades the number of natural disasters recorded around the world has risen dramatically. Between the 1960 s and the 1980 s there has been a five fold increase in the number of major disasters. Economic losses (adjusted to 1990 to eliminate the effects of inflation) have increased by a factor of 3.1 and insurance losses by a factor of 4.8 (Munich Re., 1990). There is also evidence to suggest that natural disasters are taking an increasing toll of human life, and that great regional disparities exist in the type and magnitude of losses experienced, (Degg, 1992, p. 198).

These events typify this Nation today regarding preparedness: while the number of fatalities were relatively small compared to past weather-related disasters, property damage was enormous. As shown in the accompanying table, the five most deadly weather-related events in the United States during this century occurred more than 55 years ago. In terms of damage, the five worst events have taken place in the last 25 years. This dichotomy is no 
coincidence. An increasing ability to monitor and predict calamitous weather has allowed us to provide better warnings. While people can respond and move out of harm's way, urbanization keeps increasing the value of immovable structures that are at risk, (Friday, 1993, p. 3).

...the global toll from extreme events of nature is increasing. Loss in property from natural hazards is rising in most regions of the earth, and loss of life is continuing or increasing among many of the poor nations of the world, (Burton et al, 1993, p. 1).

In the U.S. it appears that property losses from all hazards are increasing while fatalities are slowly declining, but that global hazard fatalities are increasing, (Showalter et al, 1993, p. 3).

The major problem areas consistently identified across sources are wind-related storms (including hurricanes and tornadoes), flooding, and earthquakes, (Burton et al, 1993, p. 12; Showalter et al, 1993, p. 17; FEMA, 1992, p. vi; and Friday, 1993, p. 9). While the data must be viewed with caution, Tables 3-1 and 3-2 are useful in determining the magnitude of threat that these disasters pose.

\section{Table 3-1. A Comparison Between Annual Natural Hazard Losses \\ For the Year 1970 and Projected Losses in the Year 2000 (In Millions of 1970 Dollars)}

\begin{tabular}{|c|c|c|}
\hline Type of Hazard & $\mathbf{1 9 7 0}$ & $\mathbf{2 0 0 0}$ \\
\hline Hurricane & $1,697.2$ & $5,869.2$ \\
\hline Tornado & 1,656 & $5,219.1$ \\
\hline Riverine Flood & $2,758.3$ & $3,175.3$ \\
\hline Earthquake & 781.1 & $1,553.7$ \\
\hline Expansive Soil & 798.1 & 997.1 \\
\hline Landslide & 370.3 & 871.2 \\
\hline Severe Wind & 18 & 53.4 \\
\hline Tsunami & 15 & 40.4 \\
\hline Total & $\mathbf{8 , 0 9 4}$ & $\mathbf{1 7 , 7 7 9 . 4}$ \\
\hline
\end{tabular}

Taken from a table in Showalter et al, 1993, p. 17. 
Table 3-2. Fatalities from Natural Disasters Worldwide, 1945-1986

\begin{tabular}{|l|c|c|c|}
\hline Type of Disaster & $\begin{array}{c}\text { Number of } \\
\text { Disasters }\end{array}$ & $\begin{array}{c}\text { Deaths } \\
\text { (thousands) }\end{array}$ & $\begin{array}{c}\text { Deaths per } \\
\text { Disaster }\end{array}$ \\
\hline Meteorological & & & \\
\hline Flood & 395 & 244 & 618 \\
\hline Tropical Cyclone (hurricane) & $272(271)$ & $791(291)$ & $2,907(1,072)$ \\
\hline Other Storm (incl. tornadoes) & 212 & 28 & 131 \\
\hline Extreme Temperatures & 38 & 9 & 498 \\
\hline Geological & & & \\
\hline Earthquake & $191(189)$ & $1,198(388)$ & $6,272(2,053)$ \\
\hline Volcanic Eruption & 27 & 40 & 1,494 \\
\hline Tsunami & 7 & 3 & 271 \\
\hline Other & & & \\
\hline Landslide & 85 & 25 & 295 \\
\hline Fire & 40 & 6 & 157 \\
\hline Total & $\mathbf{1 , 2 6 7 ( 1 , 2 6 4 )}$ & $\mathbf{2 , 3 4 3 ( 1 , 0 3 3 )}$ & $\mathbf{1 , 8 4 9 ( 8 3 7 )}$ \\
\hline
\end{tabular}

Numbers in parentheses exclude the three worst disasters. Table from Glickman et al, 1992, p. 10.

Windstorms (including tornadoes and hurricanes) came in for particular notice. For example, G. Berz, reporting on figures from Munich Reinsurance, one of the world's largest reinsurance companies, notes that "1990 maintained the trend of previous years: loss burdens from natural disasters are increasing dramatically; from the 1960s to the 1980 s economic losses have virtually tripled, while insured losses have even quintupled...the loss burdens from windstorms in particular will rise drastically for both national economies and the insurance industry worldwide...." (Berz, 1992, p. 95). The same source gave 1990 statistics as shown in Table 3-3.

Table 3-3. Major Natural Disasters 1990

\begin{tabular}{|c|c|}
\hline $\begin{array}{l}\text { Event Type: } \\
\text { Windstorm } 144(34 \%) \\
\text { Flood } 123(29 \%) \\
\text { Earthquake } 50(12 \%) \\
\text { Other } 103(25 \%)\end{array}$ & $\begin{array}{l}\text { Economic Losses: } \\
\text { Windstorm U.S. } 26.6 \text { B (55\%) } \\
\text { Earthquake U.S. 10.2 B (21\%) } \\
\text { Flood U.S. 4.2 B(9\%) } \\
\text { Other US 7.4 B (15\%) }\end{array}$ \\
\hline $\begin{array}{l}\text { Number Dead: } \\
\text { Earthquake } 38,161(84 \%) \\
\text { Windstorm } 3,924(9 \%) \\
\text { Flood } 2,535(5 \%) \\
\text { Other } 947(2 \%)\end{array}$ & $\begin{array}{l}\text { Insured Losses: } \\
\text { Windstorm U.S. 13.9 B (87\%) } \\
\text { Flood U.S. 0.7 B (5\%) } \\
\text { Earthquake U.S. 0.3 B (2\%) } \\
\text { Other U.S. 0.9 B (6\%) }\end{array}$ \\
\hline
\end{tabular}

Taken from Berz, 1992, pp. 98-99. 


\subsection{Natural Disaster Data}

Given the trends identified in the literature, this data collection effort focused on hurricanes/tropical storms, tornadoes, storms other than hurricanes and tornadoes, flooding, and earthquakes. Unfortunately, the data available in these areas were inconsistent and spotty, as shown in the data tables in Section 6.0.

Telephone conversations with people working in the field indicate that the data identified for this report, while perhaps not complete, are indicative of the data available and, further, represent major data sources for the natural disasters of interest in this report.

\section{Hurricanes/Tropical Storms}

A hurricane is a large cyclonic storm accompanied by high winds, extreme rainfall, and storm surge, ${ }^{2}$ (FEMA, 1992). There has been an average of ten tropical cyclones reaching storm strength with six becoming hurricanes per year for the past 40 years, (NHC, 1993, p. 16).

Historical data for the U.S. indicate a trend of increasing damage and decreasing fatalities, as shown in Figure 3-1 below.

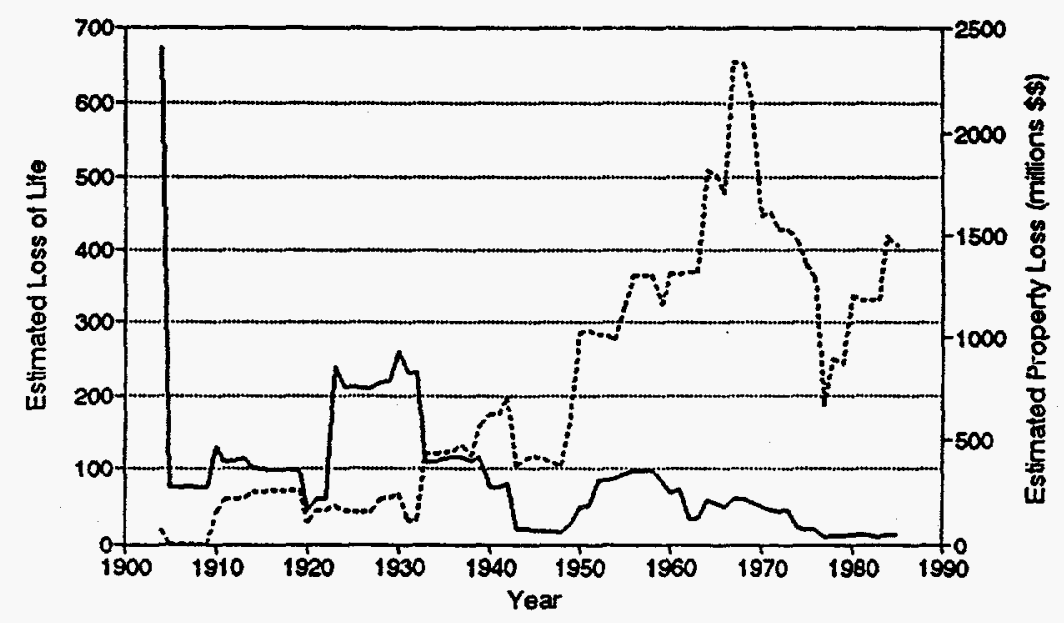

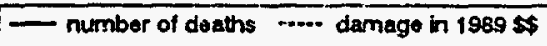

Figure 3-1. U.S. Tropical cyclone losses (10-year moving average, 1900-1990)

(U.S. Weather Service, 1990)

Source: Burton et al, 1993, p. 17.

${ }^{2}$ Storm surge is caused when the surface of the ocean is raised by the storm system and brought inland, producing significant flooding. 


\section{(U.S. Weather Service, 1990)}

Source: Burton et al, 1993, p. 17.

Although there are multiple sources of data on hurricanes and tropical cyclones, these sources show a broad range of values for damage. The best source of data appears to be the National Hurricane Center of the National Weather Service. The Center has published a list of the "deadliest and costliest" hurricanes and tropical cyclones; the list includes hurricanes in this century that have caused 25 or more fatalities or $\$ 100 \mathrm{M}$ or more in damage (then-year dollars). Because of the great diversity in data for hurricanes, the data tables in Section 6.0 contain two tables of hurricane data. Table 6-1 shows the data obtained from all sources other than the National Hurricane Center. This table highlights the differences between sources. Table 6-2 contains the data from the National Hurricane Center; the information here is more complete and, one might assume, more consistent, as it originates from one source. Table 6-2 was used to generate Figures 3-2 through 3-5.

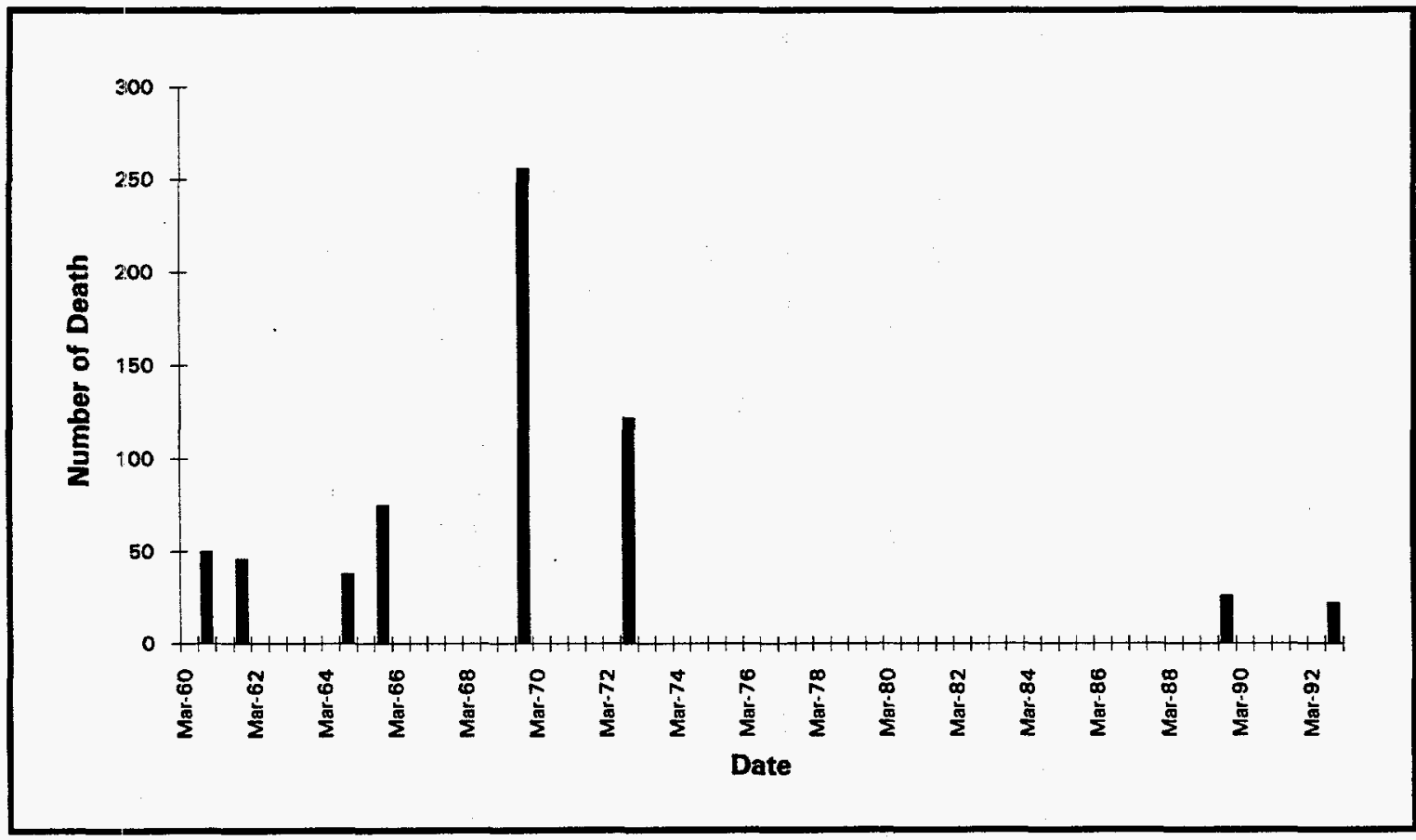

Figure 3-2. Deaths from Hurricanes Causing 25 or More Deaths 1960-1992 


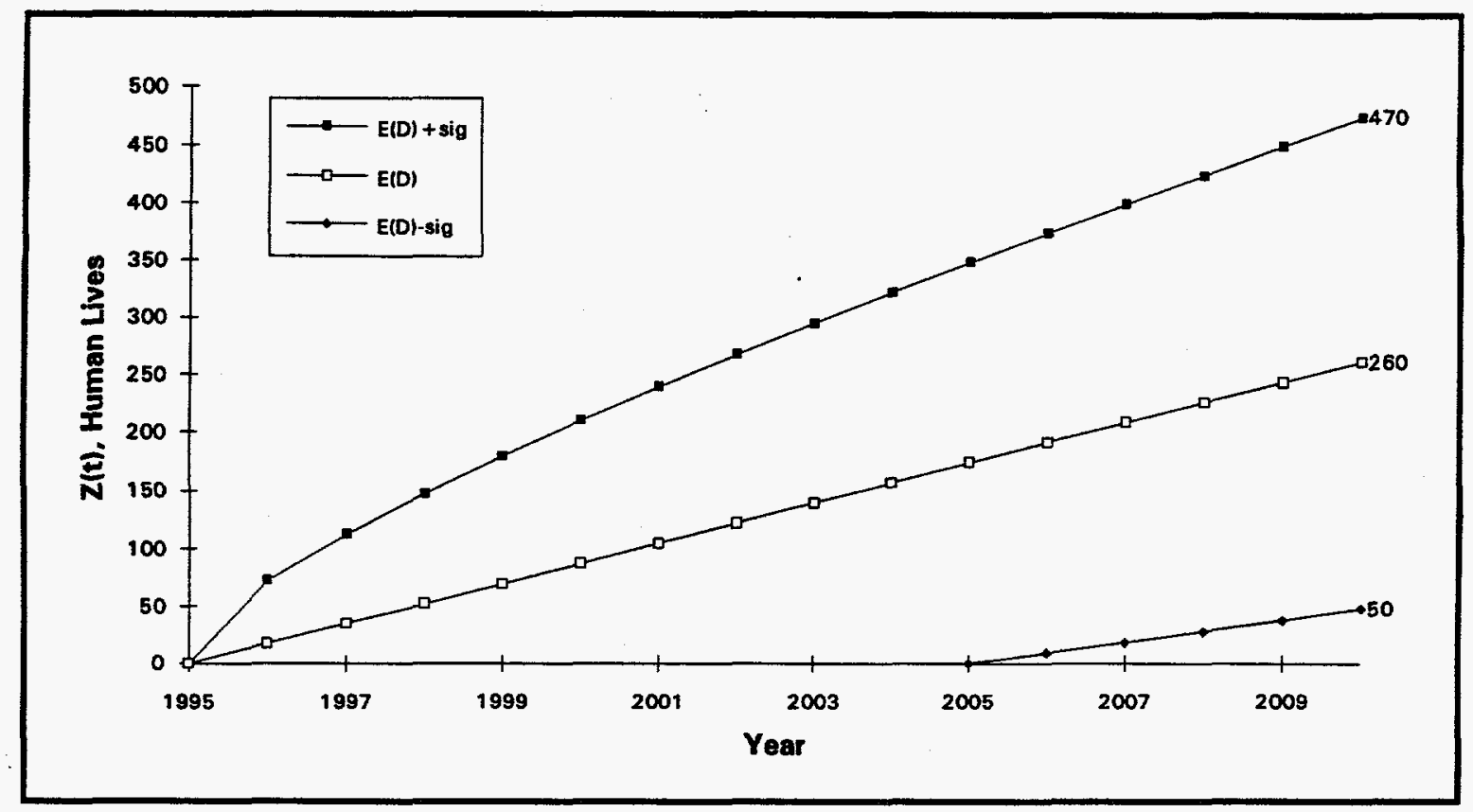

Figure 3-3. Projected Deaths from Hurricanes 1995-2010

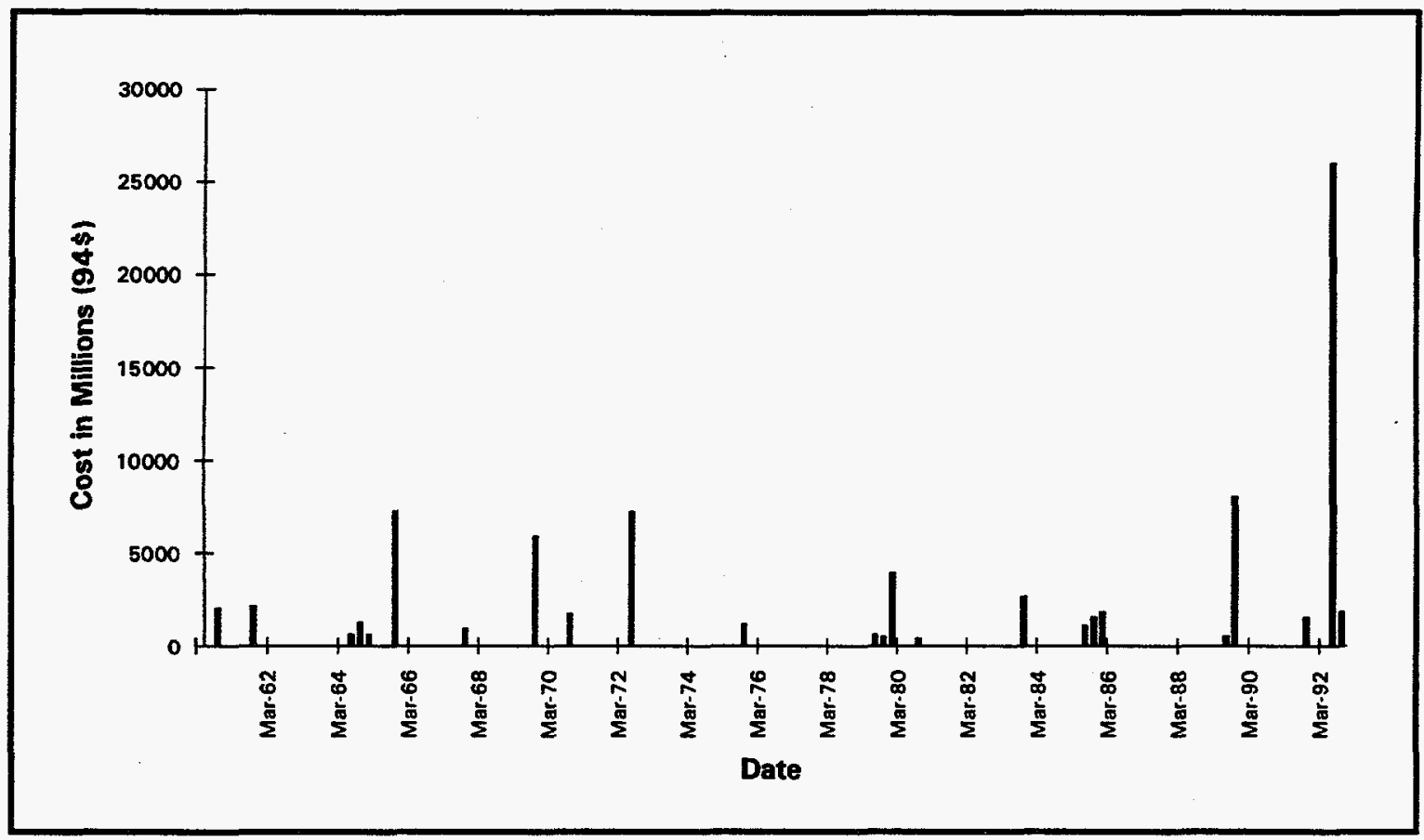

Figure 3-4. Damage from Hurricanes Causing \$100M or more in Damage (Inflated to 1990 Dollars) 


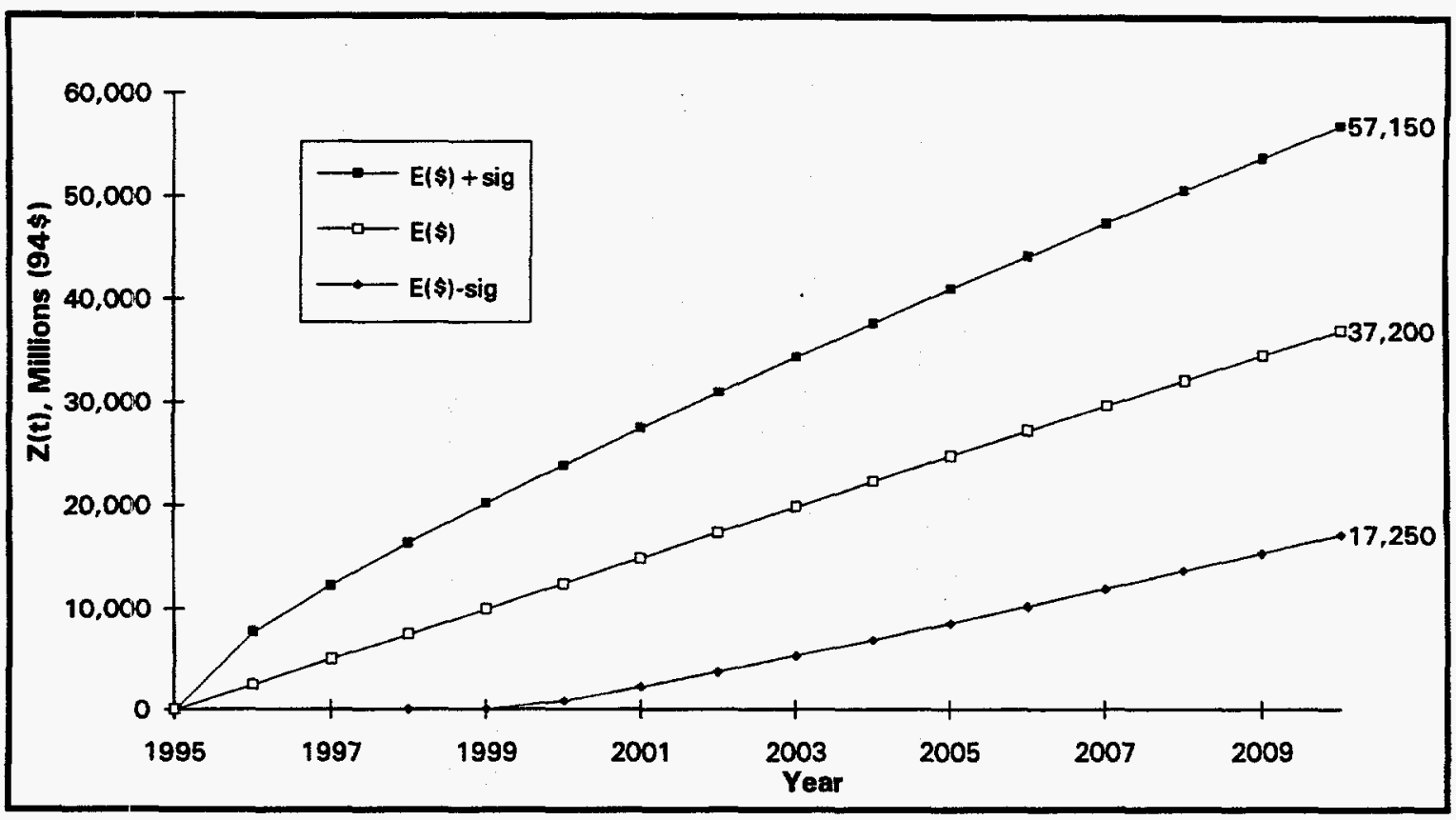

Figure 3-5. Projected Damage from Hurricanes 1995-2010

\section{Tornadoes}

A tornado is a small-radius cyclonic windstorm, (FEMA, 1992). The average number of tornadoes per year in the U.S. (from 1916-1992) is 781, with April, May, June, and July being the most active months (the means for these months in the 1953-1992 time period were $105,171,163$, and 87 respectively), (NCDC, 1992, pp. 91-92).

Because of the large number of tornadoes, they are not categorized individually, as are hurricanes, but by number of tornadoes per month. Further, damage information is extremely difficult to gather. This is reflected by the paucity of data either published by Storm Data, a monthly periodical that appears to be the best source of data on tornadoes, or mentioned in other sources. Each December's issue of Storm Data provides annual and historical summary information. The December 1992 edition, the latest annual overview, has virtually no data on damage prior to 1992. Damage for each entire year from 1960 to 1992 are categorized as $\$ 5 \mathrm{M}$ to $\$ 50 \mathrm{M}, \$ 50 \mathrm{M}$ to $\$ 500 \mathrm{M}$, or $\$ 500 \mathrm{M}$ and over. Some damage information for 1992 is included, but it is not easily quantified. Table 3-4 shows the types of damage data available about tornadoes for November 1992. 
Table 3-4. Example of Data Available on Damage from Tornadoes

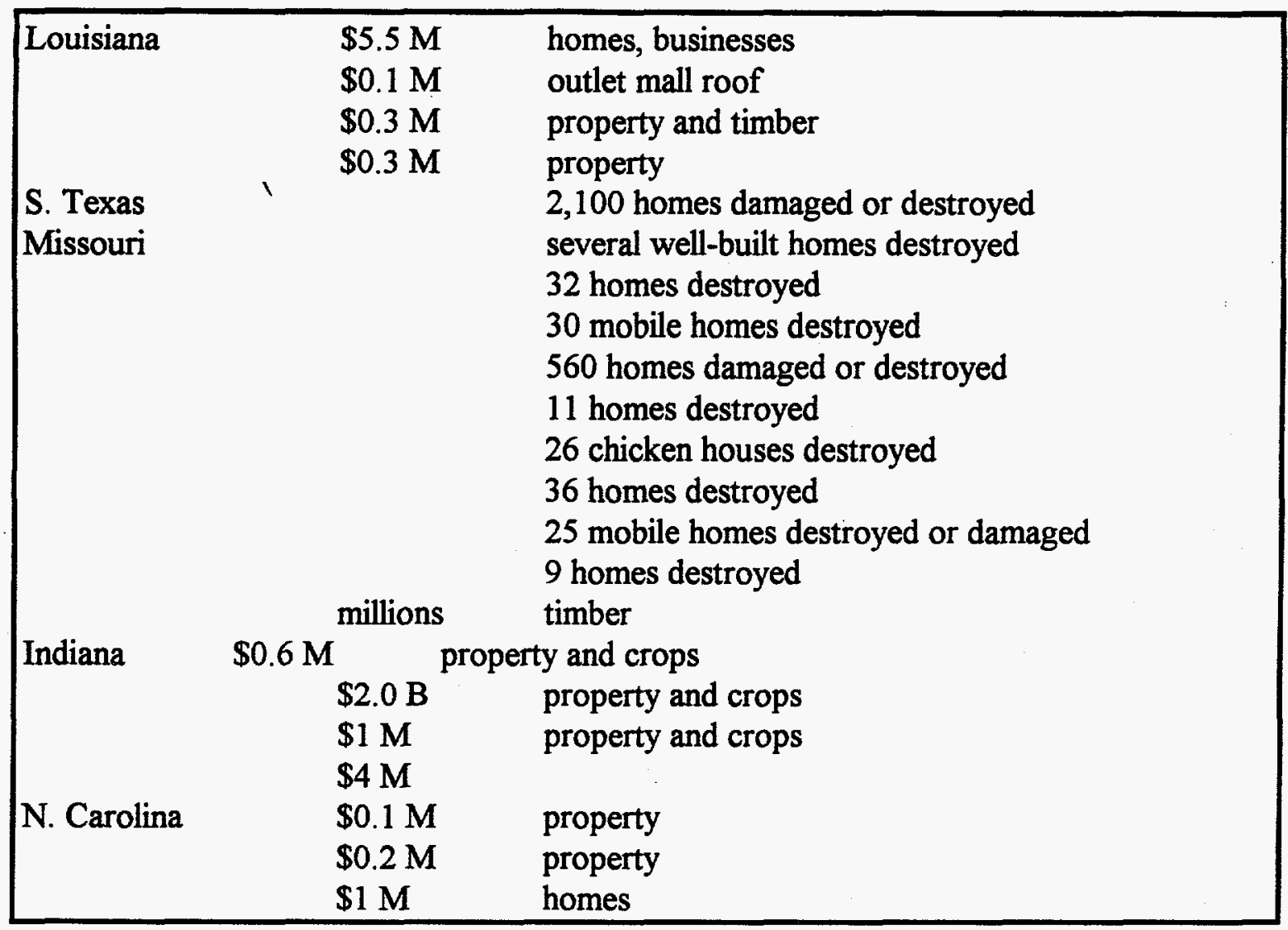

Taken from Storm Data, December 1992.

Table 6-3 of Section 6.0 shows all data found in all sources (except for Storm Data) regarding tornadoes, and Table 6-4 shows the data in Storm Data. Because Table 6-4 is the most complete set over time, and is divided by month rather than year, it has been used to create Figures 3-6 and 3-7 for tornadoes. Although the number of fatalities per month is available for each month in the time period under consideration, only those months in which there were 25 or more fatalities from tornadoes are included in the data used to generate the figures. This was done to provide somewhat greater comparability across disaster types (for example comparison with hurricanes). Reducing the number of fatalities to 10 or more per month for inclusion in the data set would slightly more than double the tornado data set. Numerical values for damage were found only for an entire year in three cases (1986, 1991 - two different values, 1992), and for a month in two cases (November 1988 and November 1992). For this reason no figures were derived for damage. 


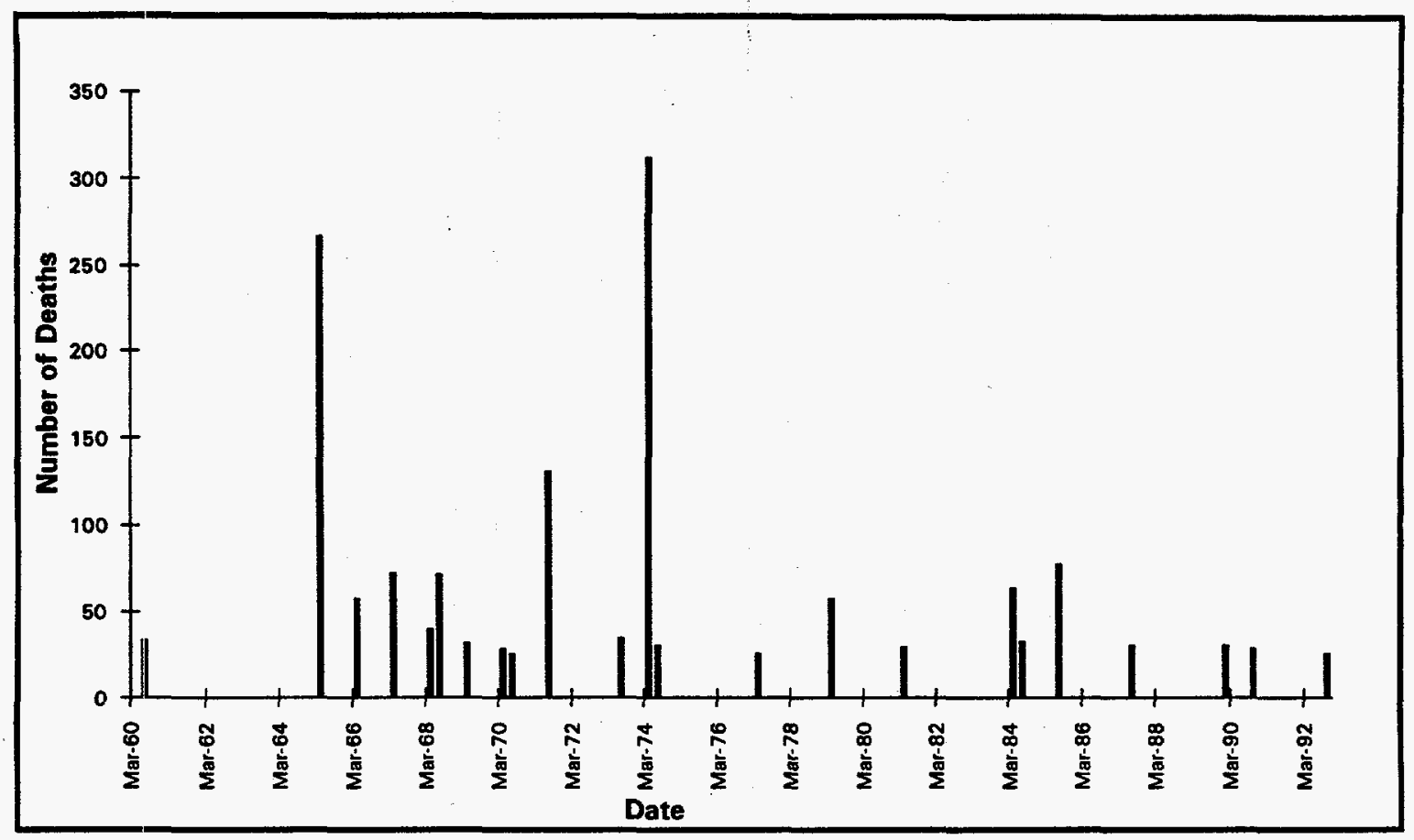

Figure 3-6. Deaths from Tornadoes in Months in Which There Were 25 or More Deaths 1960-1992

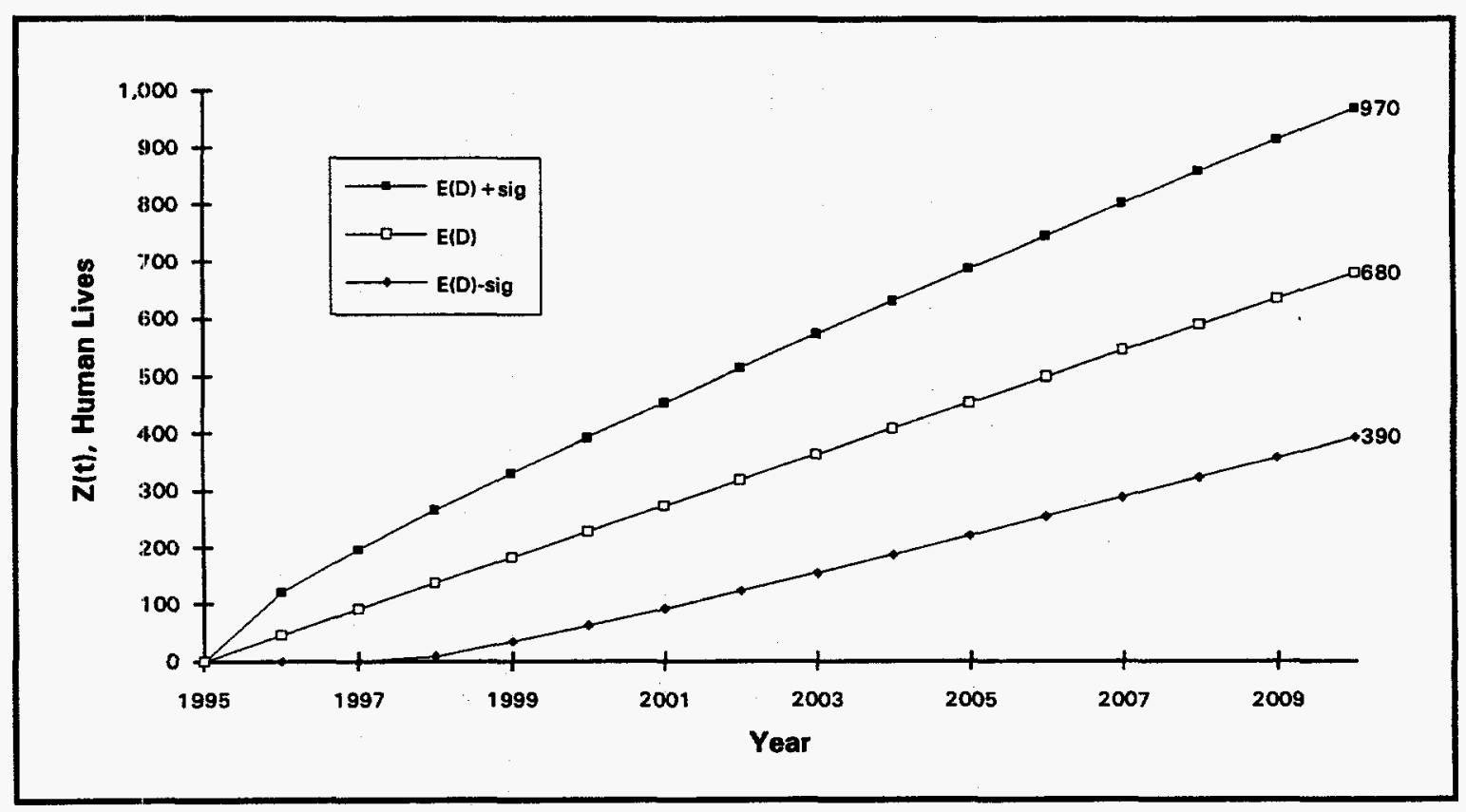

Figure 3-7. Projected Deaths from Tornadoes 1995-2010 


\section{$\underline{\text { Storms }}$}

It is difficult to determine exactly what this category includes. All of the sources reporting in this category have also reported on hurricanes, floods, and tornadoes. Where available, descriptions included events such as flooding, winter storms, hail, and tornadoes. The sources reporting data on "storms" also reported on "floods" and "tornadoes"; however, there is no way to exclude possible double-counting. This category appears to be a "catchall" for events not easily categorized, including thunderstorms, lightning storms, ice storms, blizzards, snowstorms, windstorms, and rainstorms, to suggest a few. It is included here, and as Table 6-5 in Section 6.0, because of the amount of data found regarding fatalities. The only data for damage were for 1990 , but data for fatalities were found for 1960 through 1987; therefore, Figures 3-8 and 3-9 cover fatalities only.

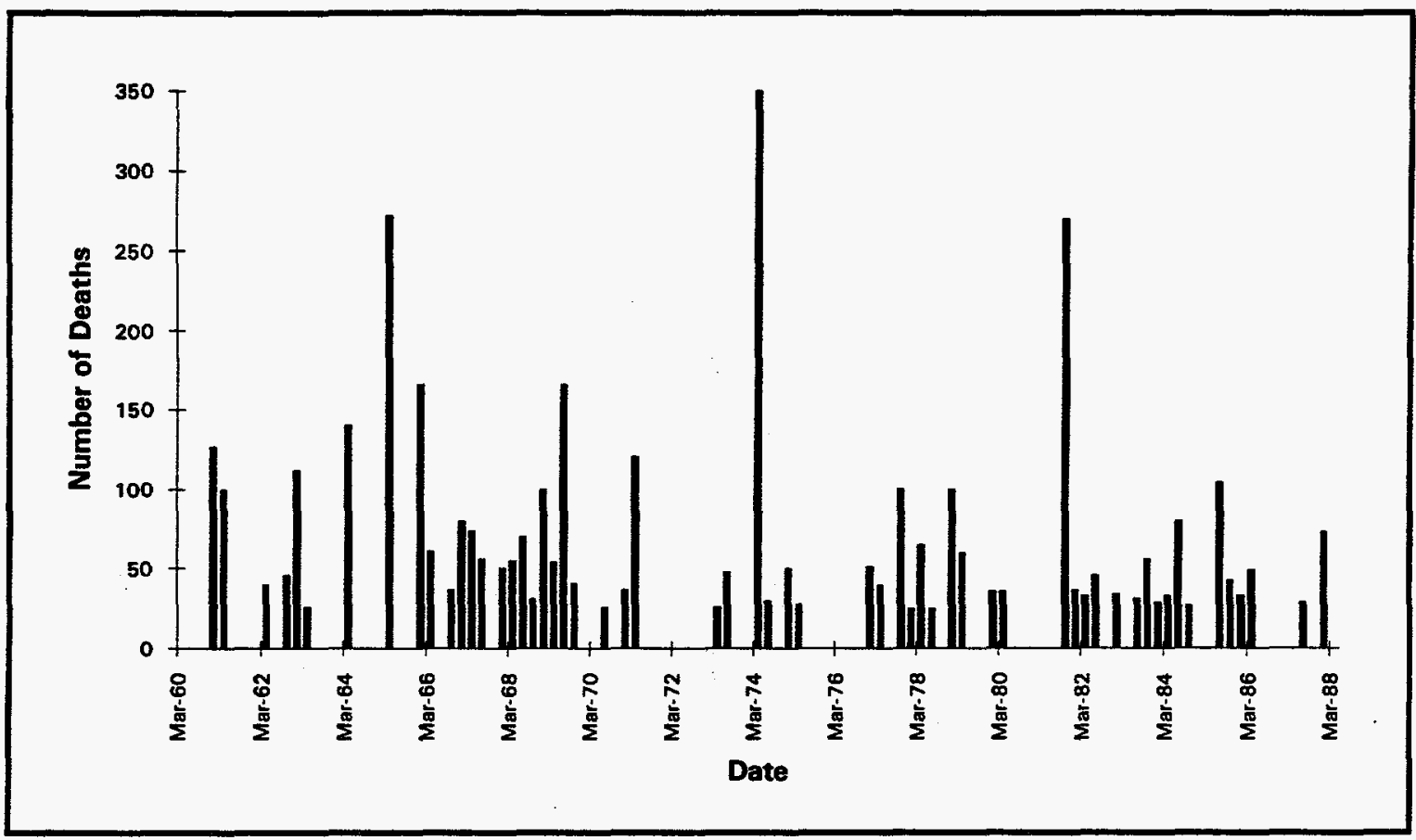

Figure 3-8. Deaths from "Storms" 1960-1987 


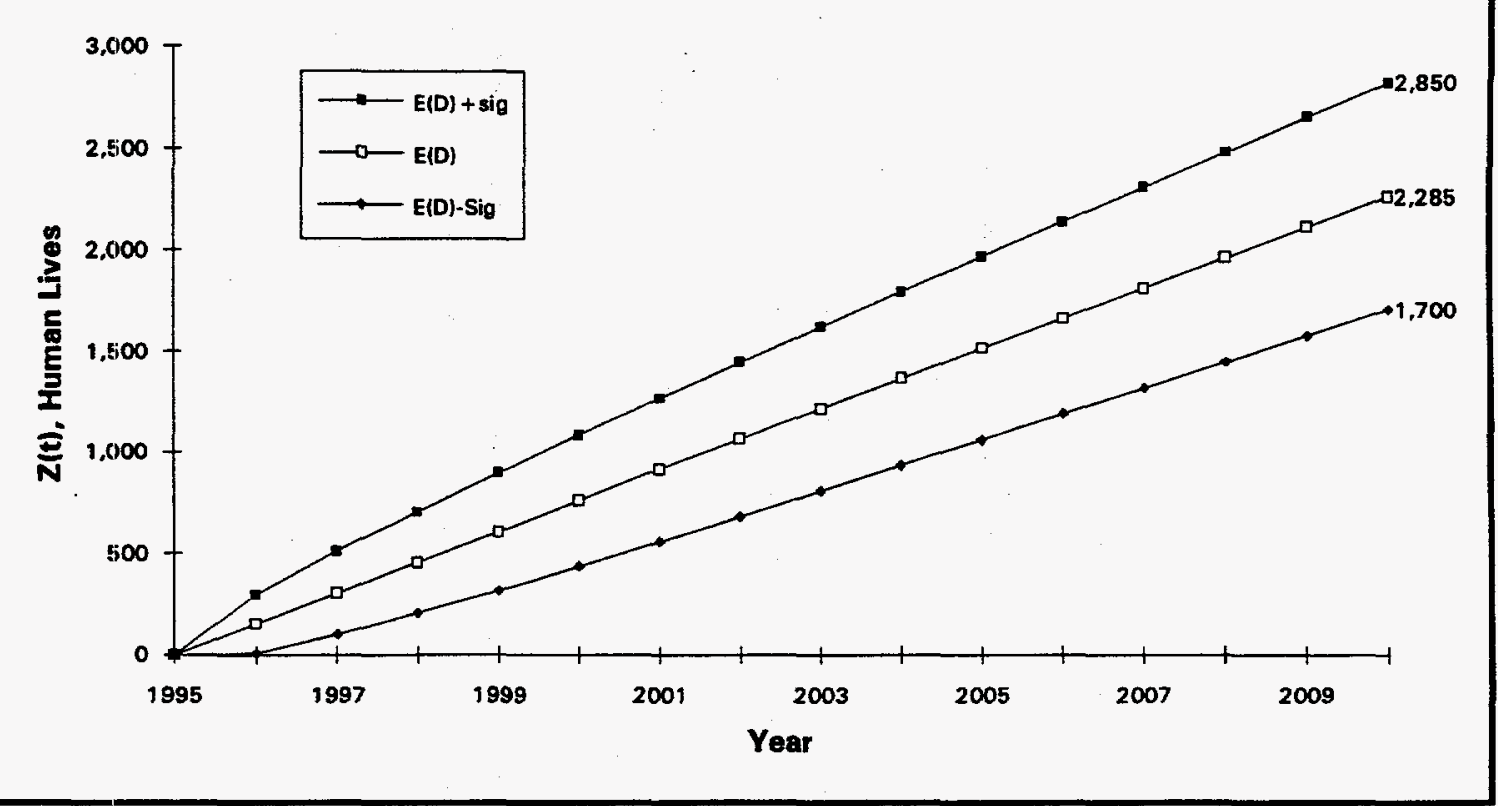

Figure 3-9. Projected Deaths from "Storms" 1995-2010

\section{Earthquakes}

An earthquake is a sudden motion of the ground that may cause surface faulting (ground rupture), ground shaking, and ground failure, (FEMA, 1992). The most complete source of data on earthquakes appears to be the National Geophysical Data Center in Boulder, Colorado. This database goes back to $2150 \mathrm{BC}$ and includes data known about earthquakes causing any fatalities or damage. Unfortunately, not many data are available. Often, damage is categorized with only a descriptive term such as "moderate" or "severe," because good quantitative estimates for damage are difficult to make. As with hurricanes, different sources give different values for damage, as shown in Table 6-6 of Section 6.0. Because the National Geophysical Data Center database is most complete, data from it were used to create Figures 3-10 through 3-13 on fatalities and deaths from earthquakes. Only those earthquakes causing 25 or more fatalities or $\$ 100 \mathrm{M}$ or more in damage were used. 


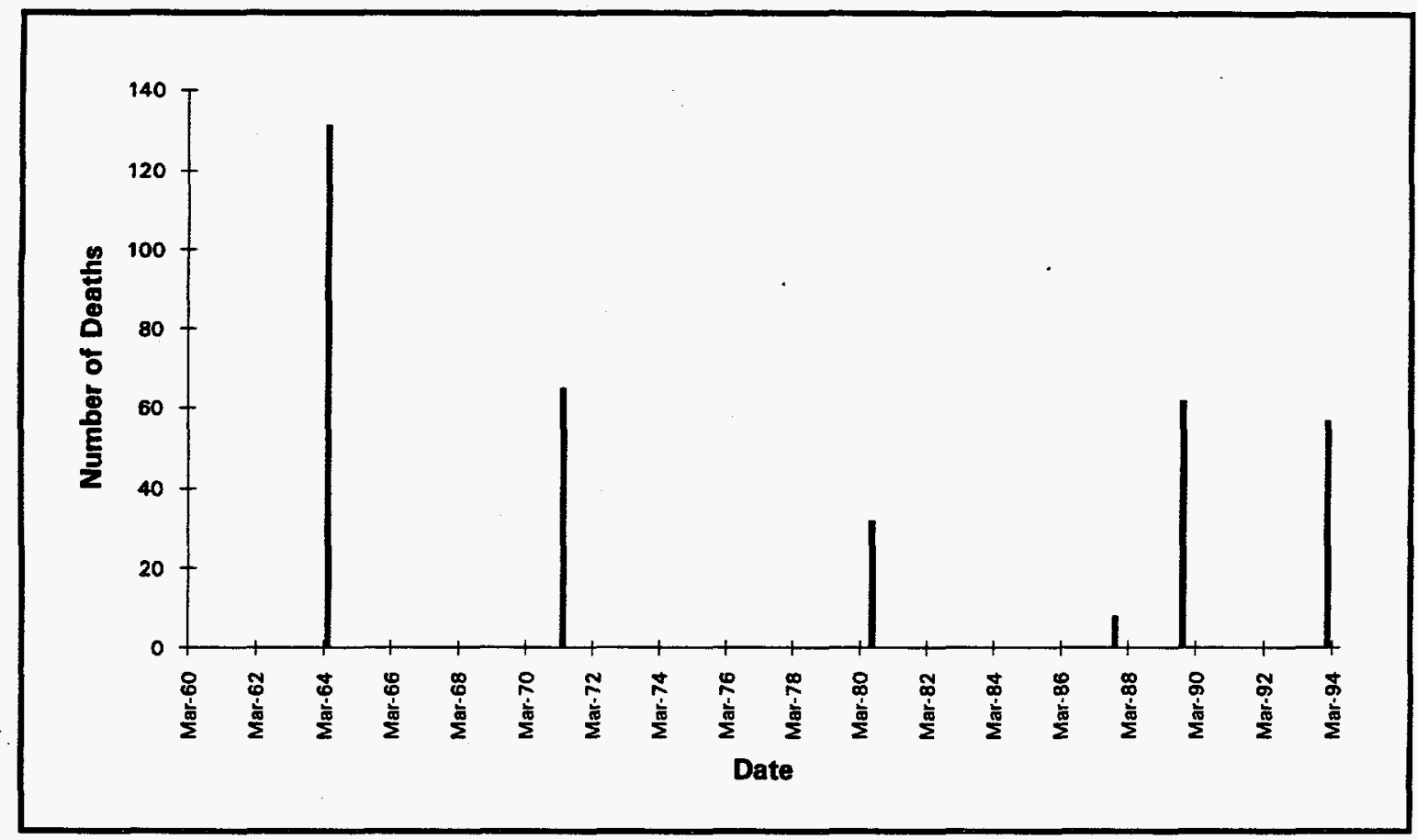

Figure 3-10. Deaths from Earthquakes 1960-1994

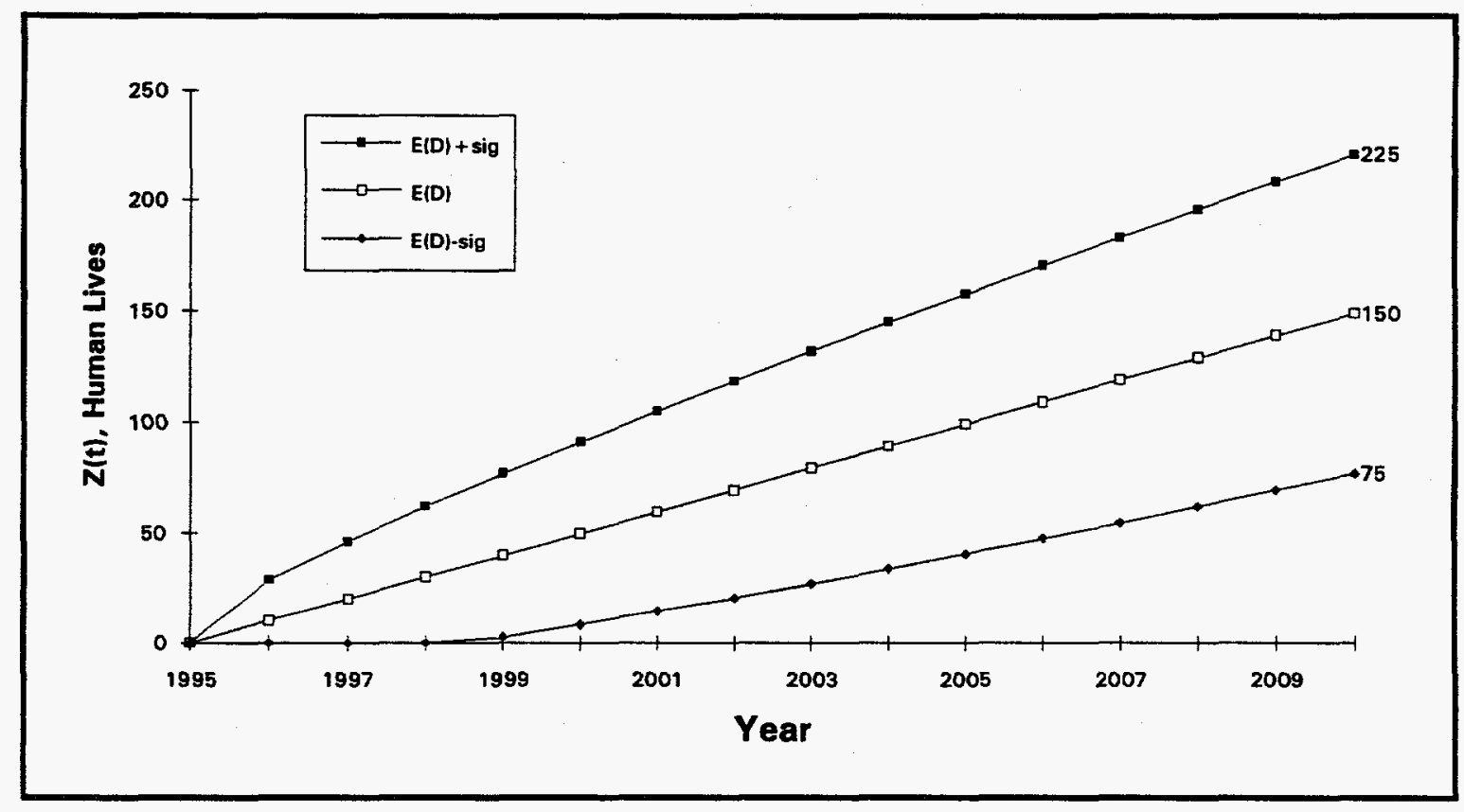

Figure 3-11. Projected Deaths from Earthquakes 1995-2010 


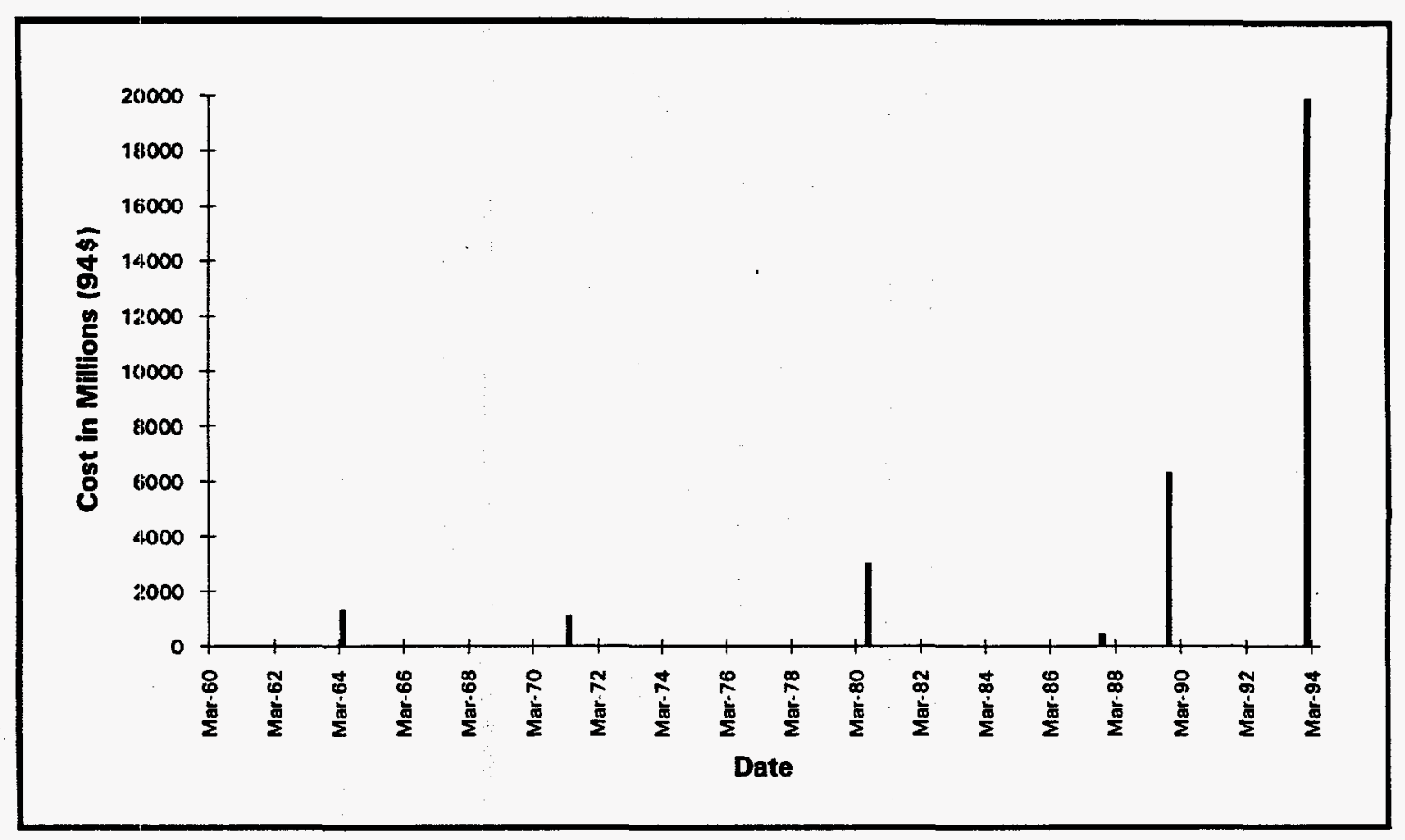

Figure 3-12. Damage from Earthquakes 1960-1994

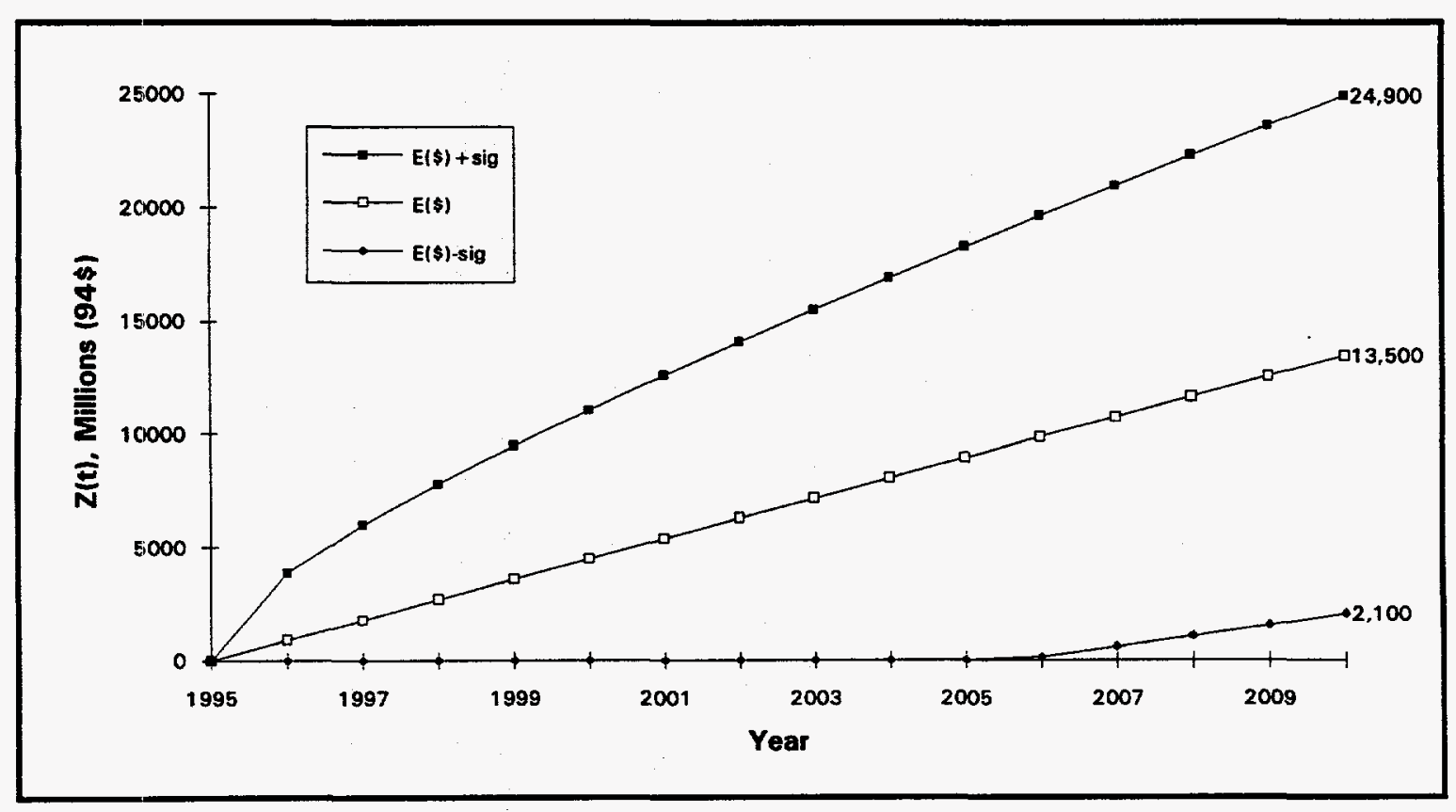

Figure 3-13. Projected Damage from Earthquakes 1995-2010

$-16-$ 


\section{Floods}

Floods are the most common natural disaster in the U.S. and constitute $90 \%$ of all presidential declarations of emergency or disaster, (Paula Dunbar, letter containing text from a report to be published in the proceedings of the International Forum on Natural Hazards Mapping, held in 1993). This group includes riverine, flash (from rain or snow melt), and urban (storm sewer overflow) floods. The sources were consistent in saying that deaths/damage from storm surges (and resulting floods) from hurricanes were included under hurricanes. The primary source of information on flooding is the Army Corps of Engineers which categorizes by year, not by individual occurrence. Damage data are also available from the same source for the years 1983 to 1992 . Although some data are available from Resources for the Future for fatalities before 1983, there are three significant breaks (of eight, two, and five years) with no data on fatalities. Moreover, these data are provided by month rather than total for the year as was the previous data. Therefore, these data were not incorporated in Figures 3-14 through 3-17. Also not incorporated are preliminary data on the summer 1993 flooding of the Mississippi River. As a result of the flooding over the course of the summer, nine states declared emergencies, about $\$ 12.5$ billion in damage was incurred, and 47 fatalities were recorded (Dunbar, letter, 1993). See Table 6-7 in Section 6.0 for the data.

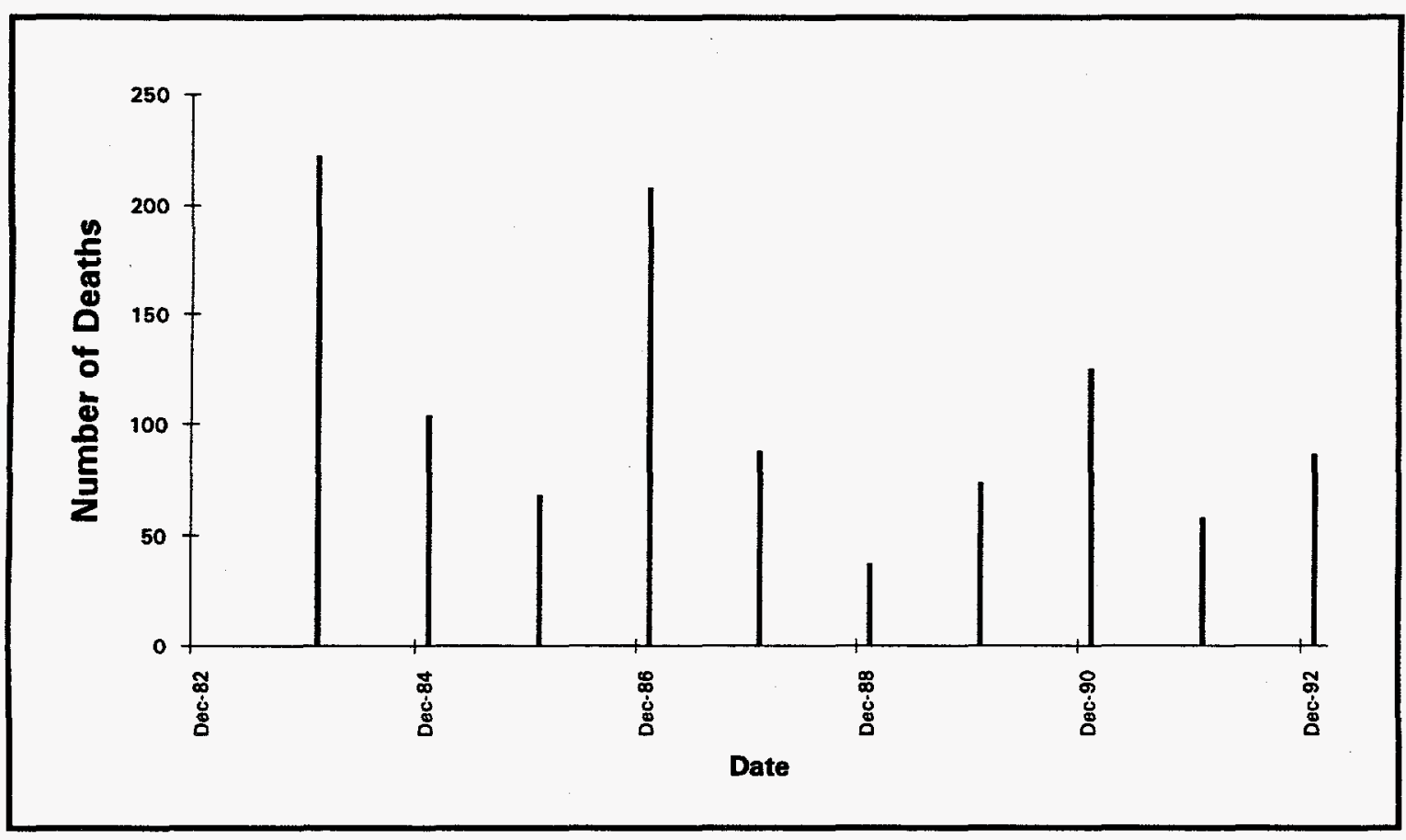

Figure 3-14. Deaths from Flooding 1983-1992 


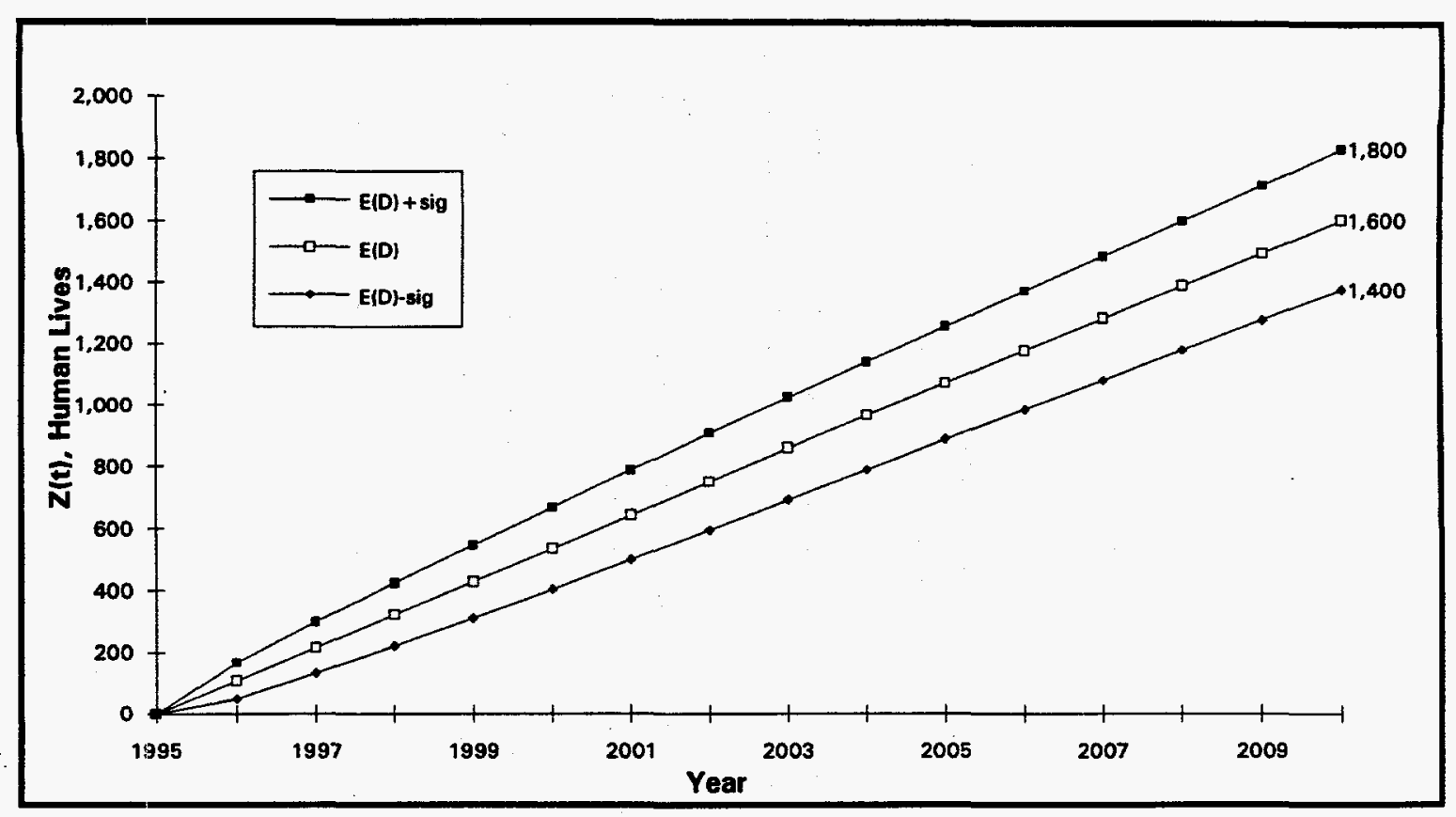

Figure 3-15. Projected Deaths from Flooding 1995-2010

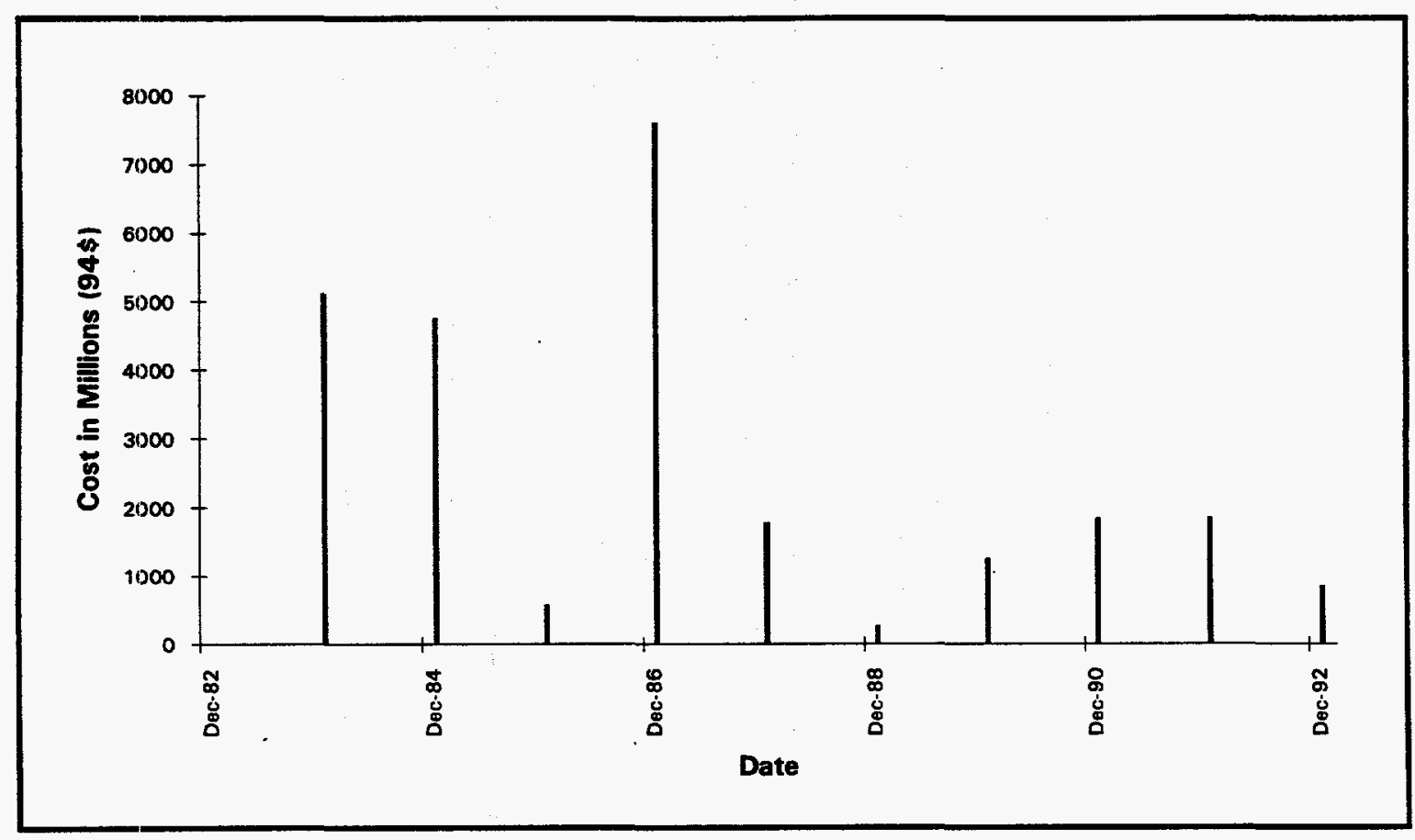

Figure 3-16. Damage from Flooding 1983-1992 


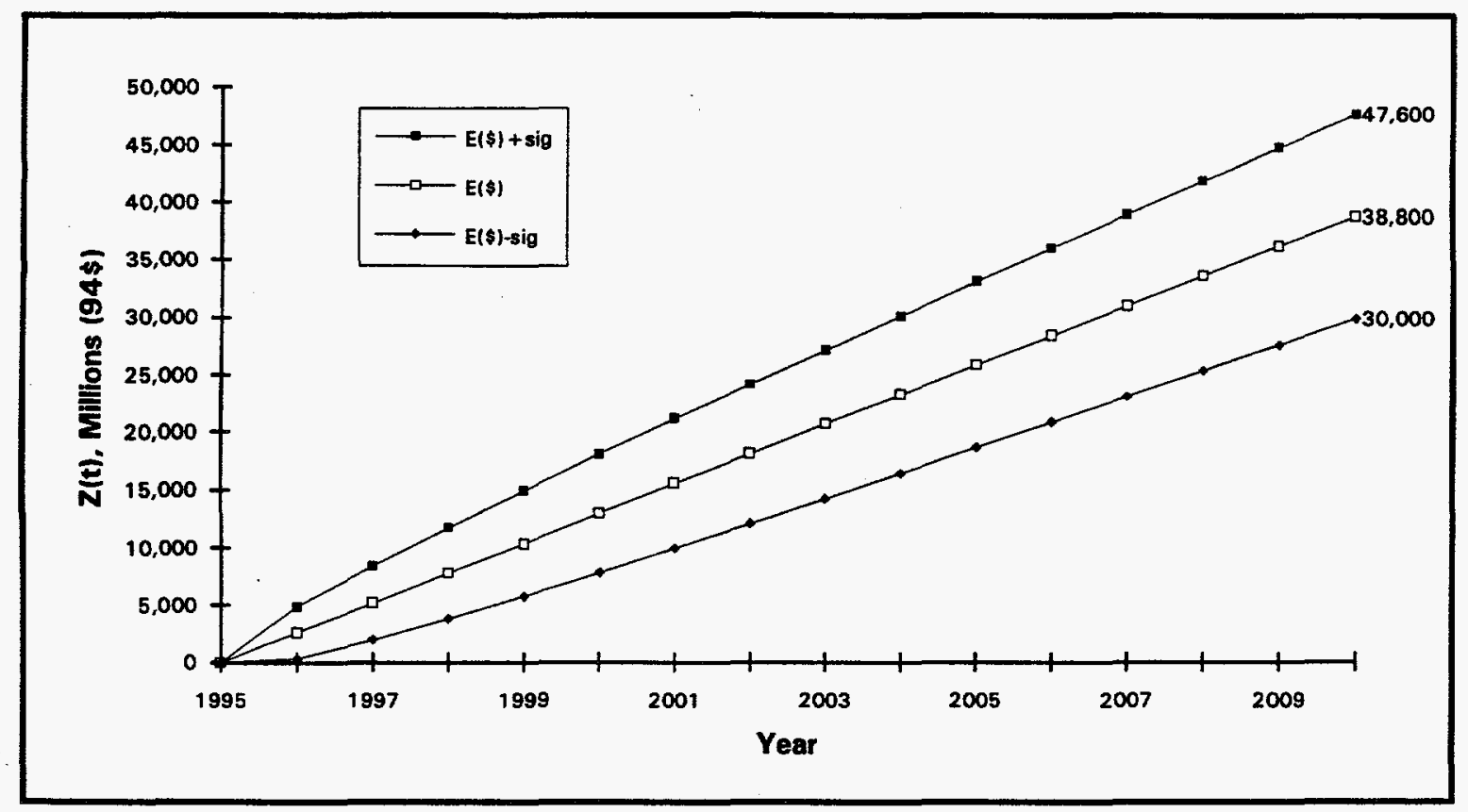

Figure 3-17. Projected Damage from Flooding 1995-2010

\section{All Natural Disasters}

The data for all natural disasters included in this report are presented together in this subsection. Figures 3-18 and 3-19 show the actual data combined and plotted for deaths and damage from all natural disasters 1960 to 1994 . Projected deaths and damage for all disasters are given in two forms: (a) as direct sums (4,975 deaths; $\$ 89.5$ billion in damage) of the renewal reward estimates for each type of disaster (Figures 3-20 and 3-21) and (b) as estimates $(3,400$ deaths; $\$ 63.4$ billion in damage) obtained by combining the data from all disasters without regard to type and using these data as inputs to the renewal reward process (Figures 3-22 and 3-23). Estimates using the combined data give the lower values $^{3}$ and may be regarded as lower bounds for the projected deaths and damage from all disasters.

3 The expected value of the total deaths $E(D)$ or total damage $E(\$)$ accumulated by time $t$ using the combined data takes the form

$$
\mathrm{E}(\mathrm{t}) \text { Combined }=\left\{\left[\lambda_{1 \mathrm{H}} /\left(\mu_{1 \mathrm{H}}+\text { additional terms }\right)\right]+\cdots+\left[\lambda_{1 F} /\left(\mu_{1 F}+\text { additional terms }\right)\right]\right\} t,
$$

which term by term is smaller than the sum of the expected values of the total deaths or total damages for all disasters $(H=$ hurricane, $\cdots, F=$ flood $)$ given by

$$
E(t)_{S u m}=\left\{\left[\lambda_{1 H} / \mu_{1 H}\right]+\cdots+\left[\lambda_{1 F} / \mu_{1 F}\right]\right\} t .
$$




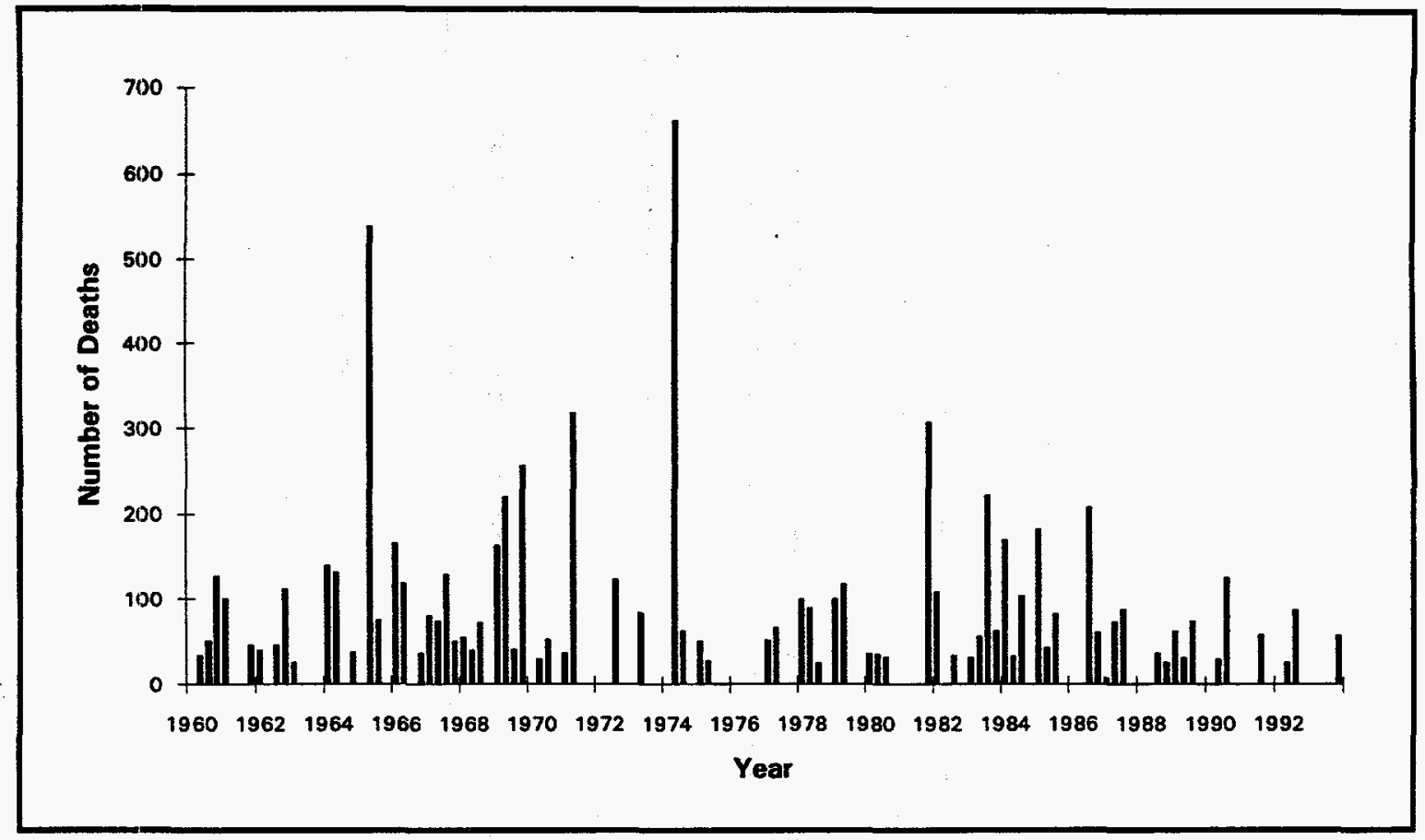

Figure 3-18. Deaths from All Natural Disasters 1960-1994

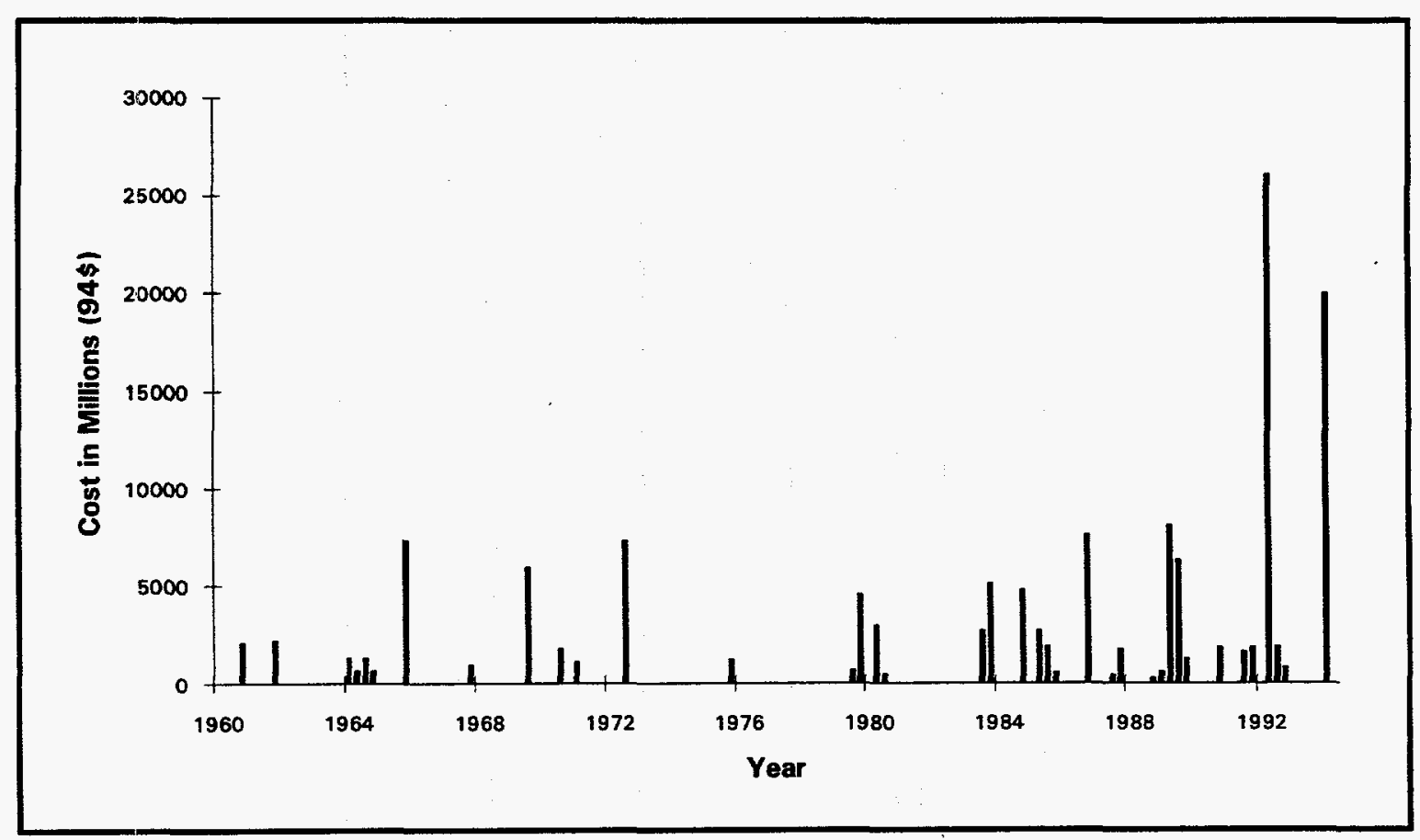

Figure 3-19. Damage from All Natural Disasters 1960-1994 


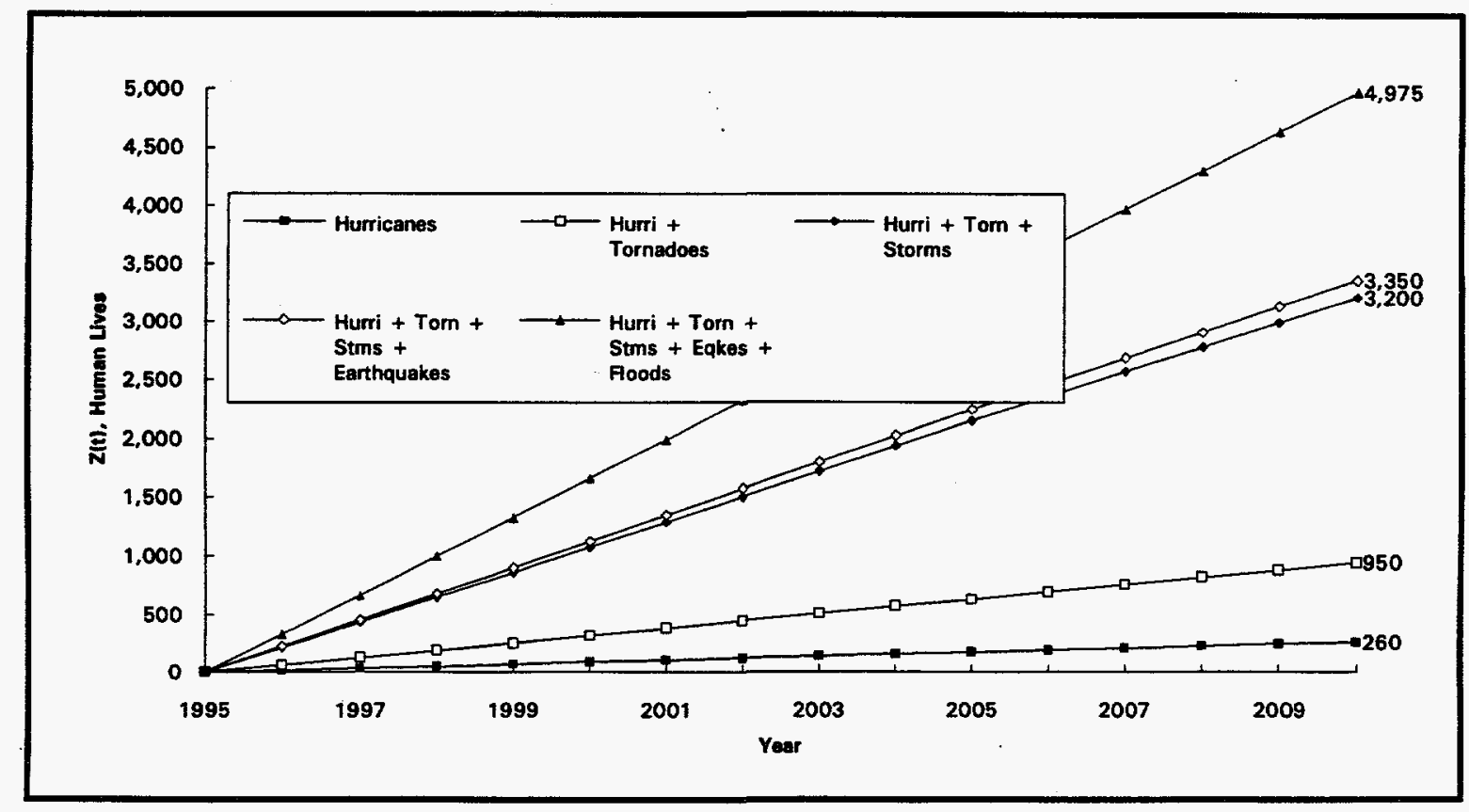

Figure 3-20. Projected Deaths (Summed) from All Natural Disasters 1995-2010

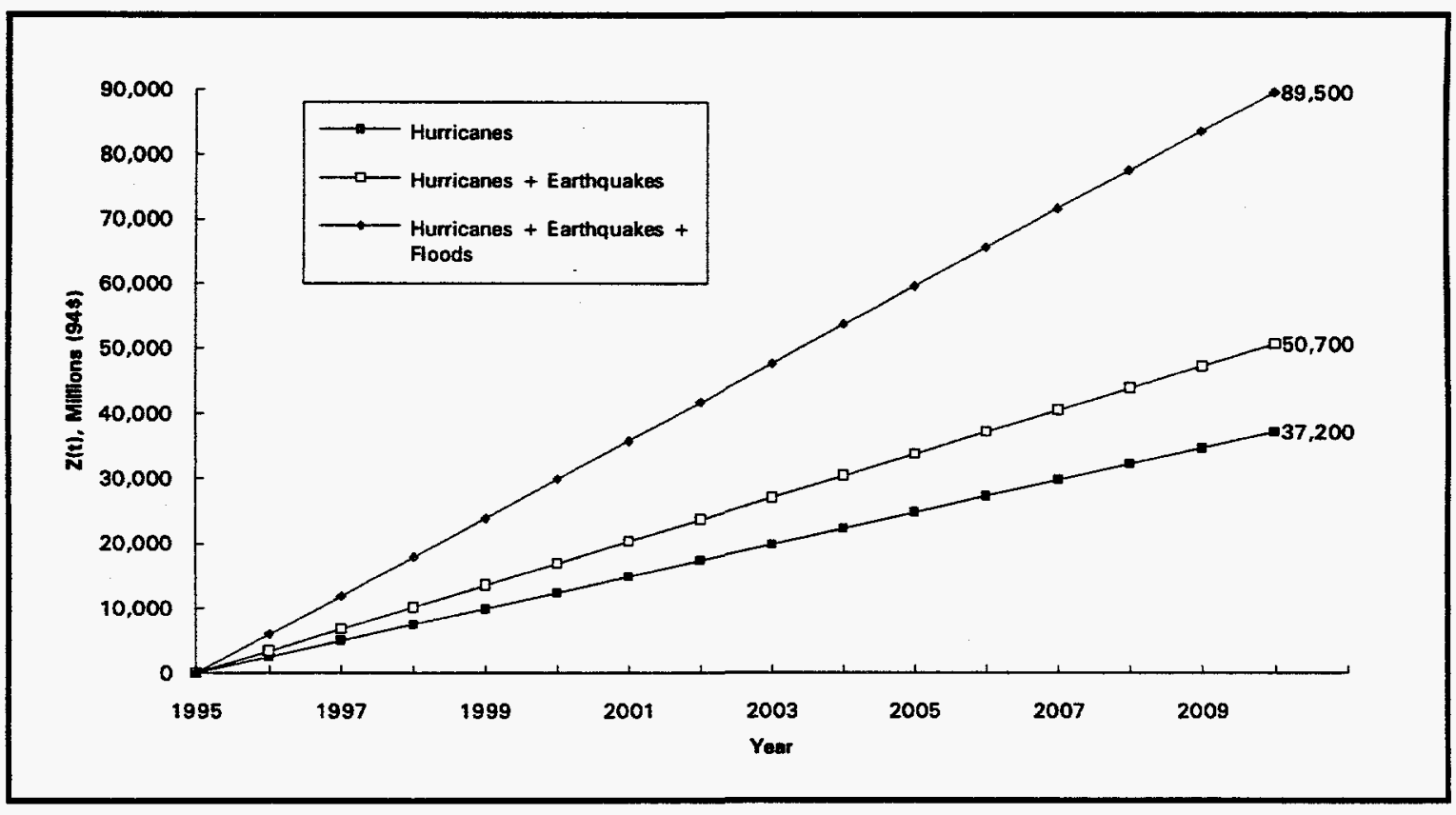

Figure 3-21. Projected Damage (Summed) from All Natural Disasters 1995-2010 


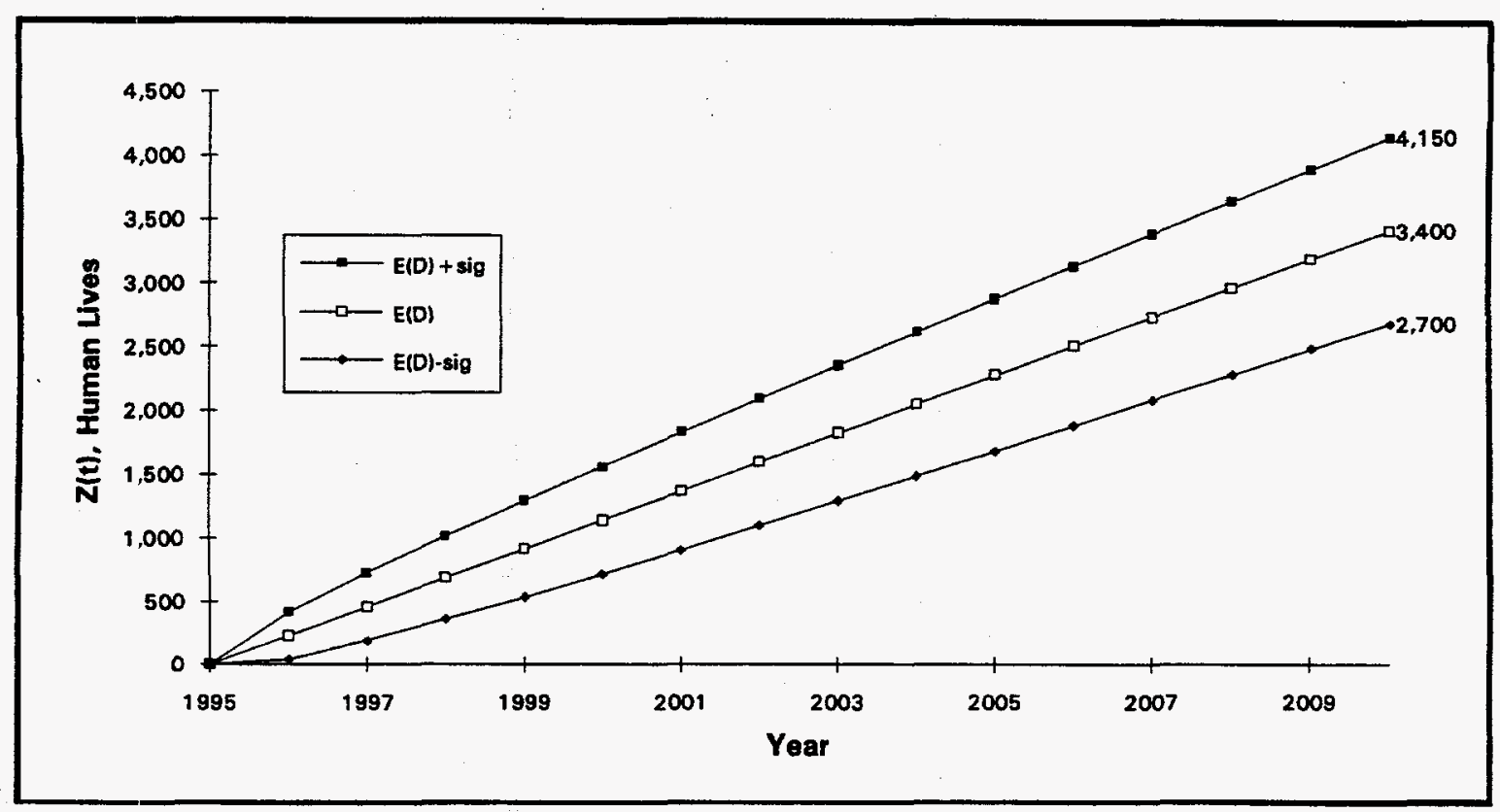

Figure 3-22. Projected Deaths (Combined Data) from All Natural Disasters 1995-2010

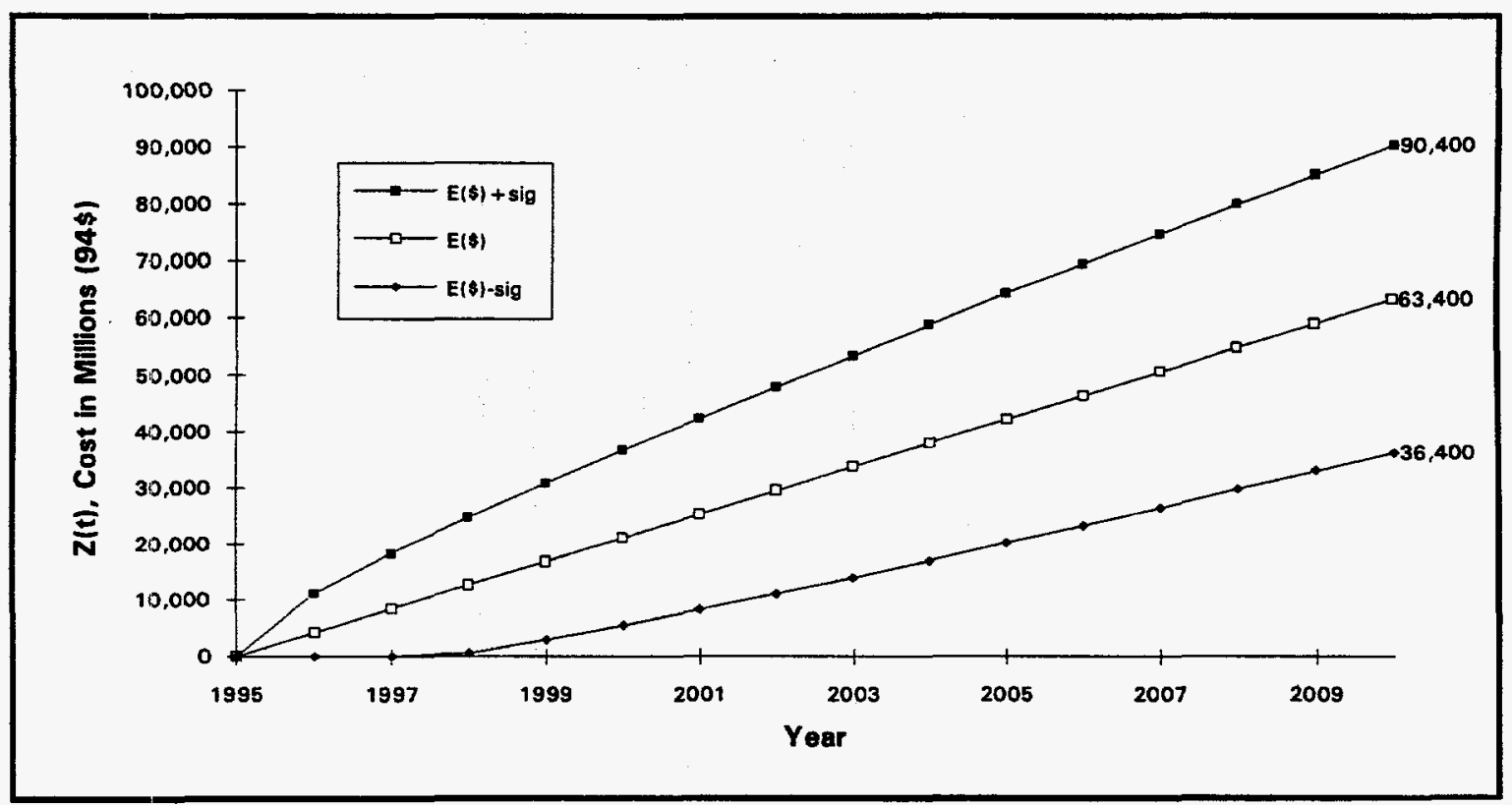

Figure 3-23. Projected Damage (Combined Data) from All Natural Disasters 1995-2010 


\subsection{Legislative Status}

The cost of natural disaster relief efforts sparked abundant debate during the two-year span of the 103rd Congress. The headline stories of the damage toll (Northridge earthquake, record floods in the Midwest, and hurricanes that battered coastlines around the country) added to the likelihood that the Congress would pass at least one of the bills pending before them, but as the 103rd Congress adjourned, no legislation had been passed.

The two bills that had the most promise in the 103rd Congress were H.R. 2873, sponsored by Rep. Mineta (D-CA) in the House, and S. 1350, sponsored by Sen. Inouye (D-HI) in the Senate. H.R. 2873 was marked up and reported out by the House Committee on Public Works \& Transportation-then chaired by Rep. Mineta - on October 7, 1994, and sent to the House for consideration. The House did not take any further action on the bill before adjournment. The Senate Committee on Commerce, Science \& Transportation completed hearings on S. 1350 on May 26, 1994, but no subsequent progress was made on the bill during the 103rd Congress.

On July 19, 1994, Rep. Burton (R-IN) introduced a Concurrent Resolution expressing the sense of Congress that the federal government should develop a comprehensive program regarding natural disasters. HConRes 267 was referred to the House Committee on Banking, Finance and Urban Affairs, but the resolution did not see any action after the date of introduction.

One jurisdictional change was instituted in the FY 95 National Defense Authorization Act. The civil defense program (i.e., the emergency preparedness program) and other portions of the FEMA budget were transferred out of the defense function to a domestic function. This change will be recognized in the FY 96 federal budget.

The change in leadership in both houses of Congress as a result of the 1994 mid-term elections will undoubtedly change the focus and thrust of natural disaster legislation. The Northridge earthquake of a year ago is still making headlines as the most expensive disaster in U.S. history with more than $\$ 5$ billion in payments to date. Rep. Burton's HConRes 267 could be introduced as legislation in the 104th Congress, thereby providing a forum for continued debate on the issue. 


\subsection{Commentary}

\section{$\underline{4.1 \text { Summary }}$}

The objective of this effort has been to locate information on fatalities and damage associated with natural disasters in the U.S. Although information about forecasting, preparing for, or mitigating natural disasters is abundant, the data on the actual effects of natural disasters are spotty and inconsistent. The data, when collected, are inconsistent in that estimates vary greatly, both in number and type, from source to source. However, even with this inconsistency, the data are consistent in indicating increasing costs of natural disasters. Because of the inconsistency of the data, comparisons of natural disasters across time or type must be made with caution. Given this proviso, the data available at this time have been used with the Renewal Reward Process to indicate, given past experience, the potential magnitude of losses from natural disasters that can be expected between 1995 and 2010. This information is available in graph form in the body of the report. Table 4-1 below summarizes projected deaths and damage from the natural disasters included in this report. ${ }^{4}$

Table 4-1. Projected U.S. Deaths and Damage (94\$) between 1995 and 2010 from Natural Disasters

\begin{tabular}{|l|r|c|}
\hline \multicolumn{1}{|c|}{ Natural Disaster } & $\begin{array}{c}\text { Deaths } \\
\mathrm{E}(\mathrm{D})\end{array}$ & $\begin{array}{c}\text { Damage } \\
\mathrm{E}(\mathrm{SM})\end{array}$ \\
\hline Hurricanes & 260 & $\$ 37,200$ \\
\hline Tornadoes & 680 & \\
\hline Storms & 2,285 & \\
\hline Earthquakes & 150 & 13,500 \\
\hline Floods & 1,600 & 38,800 \\
\hline & & \\
\hline All Disasters_Sum & 4,975 & 89,500 \\
\hline & & \\
\hline All Disasters-Combined & 3,400 & 63,400 \\
\hline
\end{tabular}

${ }^{4}$ See Section 3.3, Natural Disaster Data, for a description of the difference between summing the expected deaths and damages (an upper-bound estimate) and combining the data to derive combined expected deaths and damages (a lower-bound estimate) from natural disasters by the year 2010. 


\subsection{Conclusions}

- Natural hazards data are incomplete.

- The large number of organizations involved in natural disasters research or preparation suggests that a large amount of data may have been gathered; unfortunately these data are not readily available.

- Existing data on losses from natural disasters focus, albeit inconsistently, on fatalities and damage. The inconsistency is evidenced by the broad range of values given by different sources for the same events and by the inconsistent availability of data across time for the same type of natural disaster. Thresholds for inclusion as a "significant" natural disaster seem to cluster around 20-25 fatalities and $\$ 100$ million in damage.

- The natural disasters that appear to have the greatest scope for losses are hurricanes/tropical storms, tornadoes, storms other than hurricanes and tornadoes, flooding, and earthquakes.

- The losses due to natural disasters are significant and increasing.

- In the U.S., damage to property are increasing more rapidly than are fatalities due to natural disasters. This is reversed in less developed countries of the world.

- The U.S. Congress is currently involved in a significant effort to develop new legislation for strengthening the federal government's ability to mitigate and respond to natural disasters.

- The projected costs of natural disasters over the next 15 years are estimated to be in the range of 5,000 lives and $\$ 90$ billion $(94 \$)$.

\subsection{Recommendations}

Certainly, one significant recommendation coming from this effort is that collection of data on the effects of natural disasters needs to be systematized and made consistent to assist those organizations that are involved in mitigation of natural disasters. At a minimum, some effort needs to be made to collect or combine material from the various sources of data on damage and to arrive at some definition of what the term "damage" includes. The sources of such data include the many federal agencies that are involved in disaster. forecasting or relief, insurance or reinsurance companies, and private organizations such as the Red Cross.

Any further effort should review the issue of whether the natural disasters pinpointed for this report are the appropriate disasters on which to focus and whether additional data sources should be sought. The sheer number of organizations involved in the area of 
natural disasters suggests that although the data may not be readily available, they may exist in some form, even if that form is inconsistent. One significant source of data that needs to be pursued is the insurance and reinsurance industry.

In continuing to review data on natural disaster effects, consideration should be given to enlarging the effort to include disasters in the international arena. The U.S. State Department Agency for International Development appears to have a large database on foreign natural disasters that would be the best starting point for such an effort. In addition to the State Department, the United Nations Environment Program in New York has a large and ongoing project on mitigation of the effects of natural disasters. Neither of these sources was examined as part of this effort. 


\subsection{Institutional Perspectives}

The following organizations are involved in some aspect of national disaster research or mitigation. The information has not been verified for accuracy.

\subsection{Government}

\section{EXECUTIVE BRANCH-FEDERAL}

CENTERS FOR DISEASE CONTROL, DISASTER ASSESSMENT AND EPIDEMIOLOGY SECTION, HEALTH STUDIES BRANCH, DIVISION OF ENVIRONMENTAL HAZARDS AND HEALTH EFFECTS

Mail stop F46, 4770 Buford Highway, N.E., Atlanta, GA 30341-3724.

Eric K. Noji, M.D., Chief, (404) 488-7350; fax: (404) 488-7335.

\section{FEDERAL EMERGENCY MANAGEMENT AGENCY (FEMA)}

500 C Street, S.W., Washington, DC 20472. Director's Office, (202) 646-3923.

Assistant Associate Director, Office of Public and Intergovernmental Affairs,

(202) 646-4600.

\section{FEDERAL INSURANCE ADMINISTRATION}

Administrator's Office, (202) 646-2781.

Office of Insurance Operations - Edward T. Pasterick, Assistant Administrator, (202) 646-3443.

Office of Insurance Policy Analysis and Technical Services - Donald L. Collins, Assistant Administrator, (202) 646-3419.

Office of Insurance Support Services - James L. Taylor, Jr., Assistant Administrator, (202) 646-2771.

Office of Loss Reduction - Frank Thomas, Assistant Administrator, (202) 646-2717.

Office of Risk Assessment - John Matticks, Assistant Administrator, (202) 646-2767.

\section{STATE AND LOCAL PROGRAMS AND SUPPORT DIRECTORATE}

Associate Director's Office, (202) 646-3692.

Family Protection Program - Wayne Blanchard, (202) 646-3549.

Office of Emergency Management - John McKay, Assistant Associate Director, (202) 646-3487.

Office of Disaster Assistance Programs - Dennis Kwiatkowski, Assistant Associate Director, (202) 646-3615.

Office of Technological Hazards Programs - Joseph E. Moreland, Assistant Associate Director, (202) 646-2871.

Office of Earthquakes and Other Natural Hazards - Gary Johnson, Assistant Associate Director, (202) 646-2799.

\section{NATIONAL EMERGENCY TRAINING CENTER}

16825 South Seton Avenue, Emmitsburg, MD 21727.

Emergency Management Institute - Laura Buchbinder, Superintendent, (301) 447-1251.

U.S. Fire Administration - Edward M. Wall, Deputy Administrator, (301) 447-1080.

Learning Resource Center - Adele Chiesa, (301) 447-1030; toll free: (800) 638-1821. 
FEMA REGIONAL OFFICES

Region I (Boston) - 442 J.W. McCormack Post Office and Courthouse Building,

Boston, MA 02109-4595, (617) 223-9540; fax: (617) 223-9519.

Region II (New York) - 26 Federal Plaza, Room 1338, New York, NY 10278,

(212) 225-7208; fax: (212) 225-7245.

Region II (Philadelphia) - Liberty Square Building, 105 South Seventh Street, Philadelphia, PA 19106, (215) 931-5500; fax: (215) 931-5513.

Region IV (Atlanta) - 1371 Peachtree Street, N.E., Atlanta, GA 30309,

(404) 853-4200; fax: (404) 853-4230.

Region V (Chicago) - 175 West Jackson Boulevard, 4th Floor, Chicago, IL 60604, (312) 408-5500; fax: (312) 408-5521.

Region VI (Denton) - Federal Regional Center, 800 North Loop 288, Denton, TX

76201-3698, (817) 898-5104; fax: (817) 898-5325.

Region VII (Kansas City) - 911 Walnut Street, Room 200, Kansas City, MO 64106, (816) 283-7060; fax: (816) 759-7582.

Region VIII (Denver) - Federal Regional Center, Building 710, Box 25267,

Denver, CO 80225-0267, (303) 235-4812; fax: (303) 235-4976.

Region IX (San Francisco) - Building 105, Presidio of San Francisco,

San Francisco, CA 94129, (415) 923-7100; fax: (415) 923-7112.

Region X (Bothell) - Federal Regional Center, 130 - 228th Street, S.W.,

Bothell, WA 98021-9796, (206) 487-4600; fax: (206) 487-4707.

NATIONAL INSTITUTE OF MENTAL HEALTH, VIOLENCE AND TRAUMATIC STRESS RESEARCH BRANCH

5600 Fishers Lane, Room 10C-26, Rockville, MD 20857. Ellen Gerrity, (301) 443-3728.

NATIONAL OCEANIC AND ATMOSPHERIC ADMINISTRATION

(See also NATIONAL WEATHER SERVICE)

National Climatic Data Center, Federal Building, Asheville, NC 28801.

Office of the Chief Scientist, Paul Kilho Park, (202) 482-5483.

Primary public contact point and climatic data ordering service, (704) 259-0682.

National Environmental Satellite, Data, and Information Service, National Oceanographic Data Center,

Library and Information Services Division, WSC4, 6009 Executive Boulevard, Rockville, MD 20852.

Carol Watts, Chief, (301) 443-8330;

fax: (301) 443-0237.

National Geophysical Data Center, Code E/GC, 325 Broadway, Boulder, CO 80303. Michael Chinnery,

Director, (303) 497-6215.

Paula K. Dunbar (303) 497-6513.

National Severe Storms Laboratory, 1313 Halley Circle, Norman, OK 73069.

Robert Maddox, Director, (405) 366-0427.

Coastal Zone Information Center, Office of Ocean and Coastal Resources Management, 1825 Connecticut Avenue, N.W., Room 729, Washington, DC 20235. Sallie Cauchon, (202) 606-4115.

\section{NATIONAL SCIENCE FOUNDATION, BIOLOGICAL AND CRITICAL SYSTEMS}

1800 G Street, N.W., Washington, DC 20550.

Earthquake Hazards Mitigation Program - William Anderson, Program Director, (202) 357-9780.

Natural and Manmade Hazards Mitigation Program - Eleonora Sabadell, Program Director, (202) 357-7710. 


\section{NATIONAL WEATHER SERVICE}

Industrial Meteorology Staff (W/MM), Silver Spring Metro Center 2, Station 18462,

1325 East West Highway, Silver Spring, MD 20910. Edward M. Gross, Chief,

(301) 713-0258.

National Hurricane Center, 1320 South Dixie Highway, Coral Gables, FL 33146.

Vivien Jorge, Administrative Officer, (305) 536-5547;

Robert Sheets, Director, (305) 666-4612.

National Meteorological Center, Climate Analysis Center, W/NMC53, Room 805,

World Weather Building, Washington, DC 20223. Richard Tinker, Editor, Weekly Climate Bulletin, (301) 763-4670.

High Plains Regional Climate Center, 242 L.W. Chase Hall, University of Nebraska-Lincoln, Lincoln, NE 68583-0728. Kenneth Hubbard, Director, (402) 472-6706;

fax: (402) 472-6614.

Midwestern Climate Center, Illinois State Water Survey, 2204 Griffith Drive, Champaign, IL 618207495. Kenneth Kunkel, Director, (217) 244-8226;

fax: (217) 333-6540.

Northeast Regional Climate Center, 11th floor, 1123 Bradfield Hall, Cornell University, Ithaca, NY 14853. Warren Knapp, Director, (607) 255-1751; fax: (607) 255-2106.

Southeastern Regional Climate Center, 1201 Main Street, Suite 1100, Columbia, SC 29201.

David J. Smith, Director, (803) 737-0849; fax: (803) 765-9080.

Southern Regional Climate Center, 245 Howe- Russell Complex, Louisiana State University, Baton Rouge, LA 70803. Bob Muller, Director, (504) 388-5021;

fax: (504) 388-2912.

Western Regional Climate Center, Desert Research Institute, P.O. Box 60220, Reno, NV 89506-0220. Richard L. Rinehart, Director, (702) 677-3106; fax: (702) 677-3157.

National Severe Storms Forecast Center, Federal Building, Room 1728, 601 East 12th Street, Kansas City, MO 64106. Frederick Ostby, Director, (816) 426-5922.

Office of Hydrology, Hydrologic Operations Division, Hydrologic Services Branch, Station 8144, W/OH22, 1325 East West Highway, Silver Spring, MD 20910.

Eugene Stallings, (301) 713-0006.

Office of Meteorology, Warnings and Forecast Branch, W/OM11, Room 14360,

1325 East West Highway, Silver Spring, MD 20910. Donald Wernly, (301) 713-0090

SMALL BUSINESS ADMINISTRATION, DISASTER ASSISTANCE DIVISION

Area 1 (Connecticut, Maine, Massachusetts, New Hampshire, New Jersey, New York, Puerto Rico, Rhode Island, Vermont, Virgin Islands): 360 Rainbow Boulevard South, Third Floor, Niagara Falls, NY 14303. Sharla M. Edgar, Director, (716) 282-4612.

Area 2 (Alabama, Delaware, District of Columbia, Florida, Georgia, Illinois, Indiana, Kentucky, Maryland, Michigan, Minnesota, Mississippi, North Carolina, Ohio, Pennsylvania, South Carolina, Tennessee, Virginia, West Virginia, Wisconsin): 1 Baltimore Place, Suite 300, Atlanta, GA 30308. Richard Nash, Sr., Director,

(404) 347-3771.

Area 3 (Arkansas, Iowa, Kansas, Louisiana, Missouri, Nebraska, New Mexico, Oklahoma, Texas): 4400 Amon Carter Boulevard, Suite 102, Fort Worth, TX 76155. Raymond P. Chatham, Director, (817) 885-7600.

Area 4 (Alaska, Arizona, California, Colorado, Guam, Hawaii, Idaho, Montana, Nevada, North Dakota, Oregon, South Dakota, Utah, Washington, Wyoming): P.O. Box 13795, Sacramento, CA 95853-4795. Robert Belloni, Director, (916) 978-4578, (800) 468-1710.

TENNESSEE VALLEY AUTHORITY, FLOODPLAIN MANAGEMENT SERVICES

400 West Summit Hill Drive, Knoxville, TN 37902. Gregory W. Lowe, Manager, (615) 632-4455; Curtis W. Goff, Program Manager, (615) 632-4785; James M. Wright, Senior Technical Specialist, (615) 632-4792. 


\section{U.S. AGENCY FOR INTERNATIONAL DEVELOPMENT/ OFFICE OF FOREIGN DISASTER}

ASSISTANCE

State Department, Room 1262-A, Washington, DC 20523- 0008. Dennis King, Information Project Director, (202) 647-5707.

\section{U.S. ARMY CORPS OF ENGINEERS}

Cold Regions Research and Engineering Laboratory, 72 Lyme Road, Hanover, NH 03755-1290.

Nancy Liston, Librarian, (603) 646-4238.

Earthquake Preparedness Center of Expertise, South Pacific Division, attn: CESPD-CO-EQ, 211 Main Street, Room 302, San Francisco, CA, 94105-1905, (415) 744-2806.

Readiness Branch, attn: CECW-DE, 20 Massachusetts Avenue, N.W., Washington, DC 20314.

Edward Hecker, Chief, (202) 272-0251.

Flood Plain Management Services and Coastal Resources Branch, 20 Massachusetts Avenue, N.W., Washington, DC 20314. Jerry Peterson, Chief, (202) 272-0169.

Hydrologic Engineering Center, 609 Second Street, Davis, CA 95616. Vern Bonner, Publications \& Training, (916) 756-1104.

Water Resources Support Center, Casey Building, Fort Belvoir, VA 22060-5586.

John Singley, Sociologist, (703) 355-2219.

Waterways Experiment Station, 3909 Halls Ferry Road, Vicksburg, MS 39180-6199.

Coastal Engineering Information Analysis Center, Fred E. Camfield, (601) 634-2012.

Environmental Information Analysis Center, Roger T. Saucier, (601) 634-3233.

Hydraulic Engineering Information Analysis Center, Bobby J. Brown, (601) 634-2608.

U.S. COAST GUARD, NATIONAL RESPONSE CENTER

2100 Second Street, S.W., Room 2611, Washington, DC 20593. Commander David Beach, Chief, (800) 424-8802, (202) 267-2675.

\section{U.S. DEPARTMENT OF AGRICULTURE}

Farmers Home Administration, Room 5438, South Building, 14th and Independence Avenue, S.W., Washington, DC 20250-0700. James Redintz, Director, Farmer Programs Loan Making Division, (202) 720-1632.

Forest Service, Boise Interagency Fire Center, 3905 Vista Avenue, Boise, ID 83705. Dave Anderson, (208) 389-2603.

Forest Service, International Forestry Staff, Disaster Assistance Support, RPE-RM 710, P.O. Box 96090, Washington, DC 20090-6090. Greg Garbinsky, Program Manager, (703) 235-1278.

Forest Service, Fire, and Aviation Management, 201 14th Street, S.W., Auditors Building, Washington, DC 20250. Dennis Pendleton, Staff Economist, (202) 205-1511.

Soil Conservation Service, P.O. Box 2890, Washington, DC 20013. Ed Riekert, Director, Basin and Area Planning Division, (202) 720-2847.

U.S. DEPARTMENT OF COMMERCE, NATIONAL INSTITUTE OF STANDARDS AND TECHNOLOGY, BUILDING AND FIRE RESEARCH LABORATORY

Building 226, Room B158, Gaithersburg, MD 20899. Riley M. Chung, (301) 975-6062;

fax: (301) 869-6275.

\section{U.S. ENVIRONMENTAL PROTECTION AGENCY}

Chemical Emergency Preparedness Program, Office of Solid Waste and Emergency Response, OS-120, Washington, DC 20460.

Emergency Planning and Community Right-to-Know Hotline, (800) 535-0202.

Wetlands Division, A-104F, 401 M Street, S.W., Washington, DC 20460.

Jeanne Melanson, Chief, Outreach and State Programs Section, (202) 260-6073.

EPA Wetlands Hotline, (800) 832-7828. 


\section{U.S. GEOLOGICAL SURVEY}

Central Region GIS Laboratory, P.O. Box 25046, MS- 516, Federal Center, Denver, CO 80225.

Michael Crane, Director, (303) 236-5838.

Deputy for Research Applications, 905 National Center, Reston, VA 22092.

Walter W. Hays, (703) 648-6711/6712.

Earth Science Information Center, 507 National Center, Reston, VA 22092.

(703) 860-6045.

Earthquake Information Service, MS-967, P.O. Box 25046, Federal Center, Denver, CO 80225.

Waverly Person, Director, (303) 273-8500.

Earth Resources Observation Systems Data Center, Sioux Falls, SD 57198.

(605) 594-6511.

Geologic Inquiries Group, MS-907, National Center, Reston, VA 22092. Virginia Major, (703) 648-4383.

Hydrologic Information Unit, 419 National Center, Reston, VA 22092. Carole J. Marlow, Hydrologic Information Assistant, (703) 648-6818.

Library, National Center, MS-950, 12201 Sunrise Valley Drive, Reston, VA 22092. Information Desk, (703) 648-4302/4303.

Library, Special Video Collections, MS-955, 345 Middlefield Road, Menlo Park, CA 94025.

Michael Moore, (415) 329-5009.

National Landslide Information Center, MS-966, P.O. Box 25046, Federal Center, Denver, CO

80225-0046, (800) 654-4966; fax: (303) 273-8600;

William Brown III, Chief, (303) 273-8587. Office of Earthquakes, Volcanoes, and Engineering, 345 Middlefield Road, MS-922, Menlo Park, CA 94025.

William J. Kockelman, Earth Science Applications Planner, (415) 329-5158.

Photographic Library, MS-914, P.O. Box 25046, Federal Center, Denver, CO 80225-0046. Joe McGregor, Librarian, (303) 236-1010.

U.S. PUBLIC HEALTH SERVICE, OFFICE OF EMERGENCY PREPAREDNESS, NATIONAL DISASTER MEDICAL SYSTEM

Parklawn Building, Room 4-81, 5600 Fishers Lane, Rockville, MD 20857.

Thomas P. Reutershan, Director, (301) 443-1167.

\section{EXECUTIVE BRANCH $=$ STATE/LOCAL}

GREAT LAKES COMMISSION

400 Fourth Street, Ann Arbor, MI 48103-4816. Michael J. Donahue, Executive Director, (313) 665-9135.

NATIONAL CONFERENCE OF STATES ON BUILDING CODES AND STANDARDS

505 Huntmar Park Drive, Suite 210, Herndon, VA 22070. Deborah Brettner, Communications Specialist, (703) 437-0100.

NATIONAL GOVERNORS ASSOCIATION

444 North Capitol Street, Washington, DC 20001. Tom Curtis, Director, Natural Resources Group, (202) 624-5389.

SOUTHERN CALIFORNIA EARTHQUAKE PREPAREDNESS PROJECT, CALIFORNIA OFFICE OF EMERGENCY SERVICES

1110 East Green Street, Suite 300, Pasadena, CA 91106. Sheryl Tatieshi, Program Head, (818) 304-8383.

WESTERN STATES SEISMIC POLICY COUNCIL

Geological Survey of Wyoming, P.O. Box 3008, University Station, Laramie, WY 82071. Jim Case, Chair, (307) 766-2286. 


\subsubsection{Legislative Branch-Federal}

HOUSE COMMITTEE ON SCIENCE, SPACE, AND TECHNOLOGY (HSST)

\subsubsection{Legislative Branch—State/Local}

No entries

\subsection{Academia/Research Institutions}

\section{RESEARCH ORIENTED INSTITUTIONS}

NATIONAL RESEARCH COUNCIL, NATIONAL ACADEMY OF SCIENCES

Board on Natural Disasters, Commission on Geosciences, Environment, and Resources, Caroline Clarke Guarnizo, Ph.D., Director, (202) 334-1964

(list of publications available)

RESOURCES FOR THE FUTURE

Center for Risk Management, Theodore Glickman, Ph.D. Senior Fellow, (202) 328-5060

\section{UNIVERSITY CENTERS}

ARIZONA STATE UNIVERSITY, OFFICE OF HAZARD STUDIES Tempe, AZ 85287-0703.

Alvin H. Mushkatel, Interim Director, (602) 965-4505.

CHARLESTON SOUTHERN UNIVERSITY, EARTHQUAKE EDUCATION CENTER P.O. Box 10087, Charleston, SC 29411. Joyce Bagwell, Director, (803) 863-8088; fax: (803) 863-7533.

CLARK UNIVERSITY, CENTER FOR TECHNOLOGY, ENVIRONMENT AND DEVELOPMENT 950 Main Street, Worcester, MA 01610. Jeanne Kasperson, Research Librarian, (508) $751-4630$.

COLORADO STATE UNIVERSITY, HAZARDS ASSESSMENT LABORATORY Fort Collins, CO 80523. Dennis Mileti, Director, (303) 491-5951, (303) 491-7347.

CORNELL UNIVERSITY, CORNELL INSTITUTE FOR SOCIAL AND ECONOMIC RESEARCH, NATURAL DISASTER PROJECT

106 West Sibley Hall, Ithaca, NY 14853. Barclay G. Jones, Director, (607) 255-6846; fax: (607) 2551971.

MEMPHIS STATE UNIVERSITY, CENTER FOR EARTHQUAKE RESEARCH AND INFORMATION 3890 Central, Memphis, TN 38152. Arch Johnston, Director, (901) 678-2007.

NEW YORK MEDICAL COLLEGE, CENTER FOR PSYCHOLOGICAL RESPONSE IN DISASTER EMERGENCIES Valhalla, NY 10595. Michael Blumenfield, Director, (914) 285-8424.

SOUTHEAST MISSOURI STATE UNIVERSITY, CENTER FOR EARTHQUAKE STUDIES

One University Plaza, Cape Girardeau, MO 63701-4799. Linda M. Dillman, Associate Director, (314) 651-2019; fax: (314) 651-2316. 
TEXAS A\&M UNIVERSITY, HAZARD REDUCTION AND RECOVERY CENTER College of Architecture, College Station, TX 77843-3137. Dennis Wenger, Director, (409) 845-7813.

TEXAS TECH UNIVERSITY, INSTITUTE FOR DISASTER RESEARCH

James R. McDonald, Director, address and phone below.

WIND ENGINEERING RESEARCH CENTER

Kishor C. Mehta, Director, address and phone below.

WIND ENGINEERING RESEARCH COUNCIL

College of Architecture, Texas A\&M University, College Station, TX 77843-3137. Dale Perry, (409) 845-0052.

UNIVERSITY OF ARIZONA, OFFICE OF ARID LANDS STUDIES, and ARID LANDS INFORMATION CENTER

845 North Park Avenue, Tucson, AZ 85719. Barbara Hutchinson, Director and Librarian, (602) 6217897; fax: (602) 621-3816.

UNIVERSITY OF CALIFORNIA - BERKELEY, CALIFORNIA EARTHQUAKE EDUCATION PROJECT and SCIENCE EDUCATION FOR PUBLIC UNDERSTANDING PROJECT

Lawrence Hall of Science, Berkeley, CA 94720. Herbert Thier, Director, (510) 642-8718.

EARTHQUAKE ENGINEERING RESEARCH CENTER and NATIONAL INFORMATION SERVICE FOR EARTHQUAKE ENGINEERING

Richmond Field Station, 1301 South 46th Street, Richmond, CA 94804.

Katie Frohmberg, Information Services Manager, (510) 231-9401;

e-mail: katie@eerc.berkeley.edu.

UNIVERSITY OF COLORADO - BOULDER, NATURAL HAZARDS RESEARCH AND APPLICATIONS INFORMATION CENTER

Campus Box 482, Boulder, CO 80309-0482. Dave Morton, Librarian, (303) 492-5787;

fax: (303) 492-2151; e-mail: morton_d@cubldr.colorado.edu.

FLOODPLAIN MANAGEMENT RESOURCE CENTER

Natural Hazards Center, Campus Box 482, Boulder, CO 80309-0482. (303) 492-6818.

WORLD DATA CENTER FOR GLACIOLOGY, NATIONAL SNOW AND ICE DATA CENTER

Cooperative Institute for Research in Environmental Sciences, Campus Box 449, Boulder, CO

80309-0449. Ann Brennan, Senior Professional Research Assistant, (303) 492-1846.

UNIVERSITY OF DELAWARE, DISASTER RESEARCH CENTER

Newark, DE 19716. Joanne Nigg, Director, (302) 831-6618; fax: (302) 831-2091.

UNIVERSITY OF ILLINOIS, ENVIRONMENTAL TECHNICAL INFORMATION SYSTEM

Department of Urban and Regional Planning, 1003 West Nevada, Urbana, Il 61801. Elizabeth Dennison, Project Coordinator, (217) 333-1369.

UNIVERSITY OF LOUISVILLE, CENTER FOR HAZARDS RESEARCH AND POLICY DEVELOPMENT

Center for Urban and Economic Research, Louisville, KY 40292. Michael Cassaro, Director,

(502) 588-6276. 
UNIVERSITY OF MARYLAND-BALTIMORE COUNTY, EMERGENCY HEALTH SERVICES PROGRAM

Baltimore, MD 21228. James Eastham, Department Chair, (410) 455-3223.

UNIVERSITY OF NEBRASKA-LINCOLN, INTERNATIONAL DROUGHT INFORMATION CENTER Department of Agricultural Meteorology, 241 L.W. Chase Hall, Lincoln, NE

68583-0728. Donald A. Wilhite, Director, (402) 472-6707.

UNIVERSITY OF NEW MEXICO, SCHOOL OF MEDICINE, CENTER FOR DISASTER MEDICINE Department of Emergency Medicine, Ambulatory Care Center, 4 West, Albuquerque, NM 87131-5246. Paul B. Roth, Director, (505) 272-5062.

UNIVERSITY OF NEW ORLEANS, ENVIRONMENTAL SOCIAL SCIENCE RESEARCH INSTITUTE

Department of Sociology, New Orleans, LA 70148. Shirley Laska, Director, (504) 286-6472; fax: (504) 286-6468.

UNIVERSITY OF NORTH CAROLINA - CHAPEL HILL, CENTER FOR URBAN AND REGIONAL STUDIES

Campus Box 3410, Hickerson House, Chapel Hill, NC 27599-3410. David Brower, (919) 962-3074; fax: (919) 962-2518

UNIVERSITY OF NORTH TEXAS, EMERGENCY ADMINISTRATION AND PLANNING DEGREE PROGRAM

School of Community Service, P.O. Box 13438, NT Station, Denton, TX 76203.

Robert R. Reed, Director, (817) 565-4077.

UNIVERSITY OF PITTSBURGH, CENTER FOR SOCIAL AND URBAN RESEARCH, RISK AND EMERGENCY MANAGEMENT PROGRAM

121 University Place, Pittsburgh, PA 15260. Pamela Snyder and Jiri Nehnevajsa, (412) 624-5442.

UNIVERSITY OF SOUTHERN CALIFORNIA, SOUTHERN CALIFORNIA EARTHQUAKE CENTER Department of Geological Sciences, University Park, Los Angeles, CA 90089-0740. Thomas L. Henyey, Executive Director, (213) 740-5832; fax: (213) 740-0011.

UNIVERSITY OF WISCONSIN-EXTENSION, DISASTER MANAGEMENT CENTER

Department of Engineering Professional Development, 432 North Lake Street, Madison, WI 53706.

Don Schramm, Director, (608) 262-5441; fax: (608) 263-3160.

NATIONAL CENTER FOR EARTHQUAKE ENGINEERING RESEARCH

State University of New York at Buffalo, Red Jacket Quadrangle, Box 610025, Buffalo, NY 14261-0025. George C. Lee, Director, (716) 645-3391; fax: (716) 645-3399.

\section{INFORMATION SERVICE}

c/o Science and Engineering Library, 304 Capen Hall, Buffalo, NY 14260-2200.

Patricia Ann Coty, Manager, (716) 645-3377; fax: (716) 645-3379;

e-mail: internet: nernceer@ubvm.cc. buffalo.edu; bitnet: nernceer@ubvs.bitnet. 


\section{$\underline{5.3 \text { Industry (Insurance and Reinsurance) }}$}

INSURANCE INFORMATION INSTITUTE

110 William Street, New York, NY 10038. Jeanne Salvatore, Manager of Public Relations and Consumers, (212) 669-9200.

INSURANCE RESEARCH COUNCIL

1200 Harger Road, Suite 310, Oakbrook, IL 60521. Donald W. Segraves, Executive Director, (708) 572-1177.

NATIONAL ASSOCIATION OF INDEPENDENT INSURERS

2600 River Road, Des Plaines, II 60018. David J. Brummond, Assistant Vice President and Assistant General Counsel, (708) 297-7800.

NATIONAL COMMITTEE ON PROPERTY INSURANCE

Ten Winthrop Square, Boston, MA 02110. Eugene L. Lecomte, President and CEO, (617) 423-4620.

\subsection{Public Interest Groups}

AMERICAN RED CROSS

431 18th Street, NW, Washington, DC 20006-5399, Ricky Lopez, National Headquarters, Disaster Services, (202) 639-3400.

\subsection{Other}

EARTHQUAKE ENGINEERING RESEARCH INSTITUTE

499 14th Street, Suite 320, Oakland, CA 94612-1902. Susan Tubbesing, Executive Director, (510) 451-0905; fax: (510) 451-5411.

FIRE RESEARCH INSTITUTE/INTERNATIONAL ASSOCIATION OF WILDLAND FIRE P.O. Box 328, Fairfield, WA 99012. Jason Greenlee, Executive Director, (509) 283-2397; fax: (509) 283-2264.

HAZARD MANAGEMENT GROUP, OAK RIDGE NATIONAL LABORATORY Energy Division, Building 4500 North, MS 6206, P.O. Box 2008, Oak Ridge, TN 37831-6206. John Sorensen, (615) 576-2716; fax: (615) 576-6661; e-mail: jhs@ornlstc.bitnet.

INTERNATIONAL ASSOCIATION OF FIRE CHIEFS

4025 Fair Ridge Drive, Fairfax, VA 22033-2868. Sylindria Bynoe, Government Relations Officer, (703) 273-0911; fax: (703) 273-9363.

INTERNATIONAL CITY MANAGEMENT ASSOCIATION

777 North Capitol Street, N.E., Suite 500, Washington, DC 20002-4201.

Gerard Hoetmer, (202) 962-3634; fax: (202) 962-3500.

INTERNATIONAL CRITICAL INCIDENT STRESS FOUNDATION/ DEBRIEFING TEAM, COORDINATION CENTER

5018 Dorsey Hall Drive, Suite 104, Ellicott City, MD 21042.

Lisa A. Berg, (410) 730-4311; fax: (410) 730- 4313.

Emergency Debriefing Team Coordination Center, (410) 313-2473. 
INTERNATIONAL TSUNAMI INFORMATION CENTER

Box 50027, Honolulu, HI 96850-4993. George Pararas- Carayannis, Director, (808) 54l-1658; fax: (808) 541-1678.

NATIONAL ASSOCIATION OF FLOOD AND STORMWATER MANAGEMENT AGENCIES 1225 Eye Street, N.W., Suite 300, Washington, DC 20005. Kevin McCarty, (202) 682-3761.

NATIONAL CENTER FOR ATMOSPHERIC RESEARCH, ENVIRONMENTAL AND SOCIETAL IMPACTS GROUP

P.O. Box 3000, Boulder, CO 80307. Michael Glantz, (303) 497-8119.

NATIONAL CENTER FOR POST-TRAUMATIC STRESS DISORDER

VA Medical Center, White River Junction, VT 05009. Matthew Friedman, Director, (802) 296-5132.

NATIONAL COORDINATING COUNCIL ON EMERGENCY MANAGEMENT

7297 Lee Highway, Suite N, Falls Church, VA 22042. Elizabeth Armstrong, Executive Director, (703) 533-7672.

NATIONAL EMERGENCY MANAGEMENT ASSOCIATION

3949 Diamond Head Road, Honolulu, HI 96816-4495. Roy Price, President, (808) 734-2161.

NATIONAL FIRE PROTECTION ASSOCIATION

One Batterymarch Park, Box 9101, Quincy, MA 02269. Julie Reynolds, Assistant Public Affairs Director, (617) 984-7270; fax: (617) 770-0200.

NATIONAL INSTITUTE FOR URBAN SEARCH AND RESCUE

P.O. Box 91648, Santa Barbara, CA 93190-1648. Lois Clark McCoy, (805) 569-5066;

fax: (805) 569-3270.

SEISMOLOGICAL SOCIETY OF AMERICA

201 Plaza Professional Building, El Cerrito, CA 94530. Susan Newman, Director, (510) 525-5474; fax: (510) 525-7204.

SOCIETY FOR RISK ANALYSIS

8000 Westpark Dr, Suite 130, McLean, VA 22102. Richard J. Burk, Jr., Executive Secretary, (703) 790-1745; fax: (703) 790-9063

SOIL AND WATER CONSERVATION SOCIETY

7515 Northeast Ankeny Road, Ankeny, IA 50021-9764. Tim Kautza, Director, (515) 289-2331.

URBAN AND REGIONAL INFORMATION SYSTEMS ASSOCIATION

900 Second Street, N.E., Suite 304, Washington, DC 20002. Tom Palmerlee, Executive Director, (202) 289-1685.

VOLUNTEERS IN TECHNICAL ASSISTANCE

1600 Wilson Boulevard, Suite 500, Arlington, VA 22209. Regina Winn, Personnel Manager, (703) 276-1800. 


\subsection{Data Tables}

The following data tables show the data collected for each natural disaster. When available, the data was put into the following categories.

Year The year the event occurred.

Rpts "Repeats" Indicates events for which there were different reports of effects. This category is provided to show the wide range in effects reported for an individual event. Where it is uncertain whether more than

Mth "Month" The month the event occurred. If the number is for the entire year, the number 13 is used.

Place/Name The location of the event.

Fatalities The number of fatalities reported. If a range was given, it is placed to the left of the column.

Damage The damage reported for the event. Unless otherwise reported, the damage are in then-year dollars. If a range was given it is placed to

the left of the column.

Insur

References The dollars paid by insurance companies for the event. There is no way to tell to what extent these values are included in the "Damage" value. Indicates source of information, full reference in Section 8.0 Bibliography. If this column is blank it is because there is a mass reference in the title or at the bottom of the table. 
TABLE 6-1: HURRICANES--ALL SOURCES EXCEPT NHC-93

\begin{tabular}{|c|c|c|c|c|c|c|c|}
\hline Year & Ripts & Mth & Place/Name & Fatalities & Damage \$M & $\begin{array}{l}\text { Insur } \\
\$ M\end{array}$ & References \\
\hline 1992 & & 13 & total $=8$ & 51 & 30,000 & & ACEng 93 \\
\hline 1992 & ${ }^{*} B$ & 9 & Iniki & 3 & 1,800 & & ACEng 93 \\
\hline 1992 & ${ }^{*} B$ & 9 & Iniki & 4 & 1,800 & & Friday 93 \\
\hline 1992 & *B & 9 & Iniki: HA & & $\begin{array}{l}1,000- \\
1,600\end{array}$ & & Show 94 \\
\hline 1992 & $* A$ & 8 & Andrew: $F L$ & & 16,500 & & Show 94 \\
\hline 1992 & $* A$ & 8 & Andrew: $F L$, LA & 22 & 25,000 & & Friday 93 \\
\hline 1992 & $* A$ & 8 & Andrew: FL, LA & 50 & $\begin{array}{l}20,000- \\
30,000\end{array}$ & & ACEng 93 \\
\hline 1992 & $* A$ & 8 & Andrew: $\mathrm{FL}$ & $25-50$ & 5,000 & & Burton 93 \\
\hline 1991 & & 8 & Bob: New England & 17 & 1,500 & & Show 94 \\
\hline 1991 & & 13 & & 13 & 1,164 & & NWS 91 \\
\hline 1989 & $* 1$ & 9 & Hugo & & 4,500 & & Munich RE \\
\hline 1989 & $* 1$ & 9 & Hugo & 26 & 9,200 & 365 & FEMA 92 \\
\hline 1989 & $* 1$ & 9 & Hugo & & 10,000 & 4,500 & Show 93 \\
\hline 1989 & $* 1$ & 9 & Hugo & 26 & 7,500 & & Friday 93 \\
\hline 1989 & $* 1$ & 9 & Hugo & 20 & 5,000 & & Burton 93 \\
\hline 1985 & & & Kate: FL, GA & 5 & & & CDC 89 \\
\hline 1985 & & 10 & Juan: LA, Miss, FL & 12 & & & CDC 89 \\
\hline 1985 & & 9 & Gloria: NC and north & 8 & & & CDC 89 \\
\hline 1980 & & 6 & & 40 & & & RFF 92 \\
\hline 1979 & *? & 9 & Frederic: $A L, M S$ & & $2,550 \$ 80$ & & FEMA 92 \\
\hline 1979 & $* ?$ & 9 & & 31 & & & RFF 92 \\
\hline 1979 & & 7 & Claudette: $T X$ & & $444 \$ 80$ & & FEMA 92 \\
\hline 1976 & & 9 & & 45 & & & RFF 92 \\
\hline 1975 & & 9 & Eloise & & $880 \$ 80$ & & FEMA 92 \\
\hline 1972 & $* ?$ & 6 & & 134 & & & RFF 92 \\
\hline 1972 & $* 2$ & 6 & Agnes: NE US & 122 & & & CDC 89 \\
\hline 1972 & $* 2$ & 6 & Agnes & 122 & $4,700 \$ 80$ & & FEMA 92 \\
\hline 1972 & $* 2$ & 6 & Agnes & 122 & 7,000 & & Friday 93 \\
\hline 1972 & $* 2$ & 6 & Agnes & & 8,000 & & Show 93 \\
\hline 1972 & $* 2$ & 6 & Agnes: NE US & 118 & 3,500 & & Burton 93 \\
\hline 1970 & *? & 8 & Celia: South TX & & $1,142 \$ 80$ & & FEMA 92 \\
\hline 1970 & $* ?$ & 8 & & 32 & & & RFF 92 \\
\hline 1969 & *? & 8 & & 400 & & & RFF 92 \\
\hline 1969 & $* 3$ & 8 & Camille & 256 & 3,810 & & FEMA 92 \\
\hline 1969 & $* 3$ & 8 & Camille & & 1,300 & & Show 93 \\
\hline 1969 & $* 3$ & 8 & Camille: Miss, LA & 256 & & & CDC 89 \\
\hline
\end{tabular}


Table 6-1 continued

\begin{tabular}{|c|c|c|c|c|c|c|}
\hline 1967 & & 9 & Beulah: S TX & & $608 \$ 80$ & FEMA 92 \\
\hline 1965 & & 9 & & 299 & & RFF 92 \\
\hline 1965 & $* 4$ & 9 & Betsy & 75 & $4,670 \$ 80$ & FEMA 92 \\
\hline 1965 & $* 4$ & 9 & Betsy & 75 & 7,200 & Friday 93 \\
\hline 1965 & $* 4$ & 9] & Betsy: FL, LA & 75 & & CDC 89 \\
\hline 1964 & $* 5$ & 10 & & 38 & & RFF 92 \\
\hline 1964 & $* 5$ & 10 & Hilda: LA & 38 & & CDC 89 \\
\hline 1964 & & 9 & Dora: NE FL & & $850 \$ 80$ & FEMA 92 \\
\hline 1962 & & 10 & & 25 & & RFF 92 \\
\hline 1961 & ${ }^{*} 6$ & 9 & & 51 & & RFF 92 \\
\hline 1961 & ${ }^{*} 6$ & 9 & Carla:TX & & $1,412 \$ 80$ & FEMA 92 \\
\hline 1961 & $* 6$ & 9 & Carla: TX & 46 & & CDC 89 \\
\hline 1960 & & 9 & & 240 & & RFF 92 \\
\hline 1960 & $* 7$ & 9 & Donna: $F L$, east U.S. & 50 & & CDC 89 \\
\hline 1960 & $* 7$ & 9 & Donna: $F L$, East Coast & & $1,335 \$ 80$ & FEMA 92 \\
\hline
\end{tabular}




\begin{tabular}{|c|c|c|c|c|c|c|c|}
\hline \multicolumn{8}{|c|}{ TABLE 6-2: } \\
\hline Year & Rpts & Mth & Place/Name & Fatalities & Damage $\mathrm{M}$ & \begin{tabular}{|l} 
Insur \\
$\$ M$
\end{tabular} & References \\
\hline 1992 & & & Iniki & & 1,800 & & \\
\hline 1992 & & 8 & 8 Andrew & & 25,000 & & \\
\hline 1991 & & 8 & \begin{tabular}{|l|l|}
$B o b$ \\
\end{tabular} & & 1,500 & & \\
\hline 1989 & & 9 & $9 \mid$ Hugo & 26 & 7,155 & & Friday 93 \\
\hline 1989 & & 6 & Allison & & 511 & & \\
\hline 1985 & & 10 & Juan & & 1,671 & & \\
\hline 1985 & & 9 & 9 Gloria & & 1,003 & & \\
\hline 1985 & & 9 & 9 Elena & & 1,393 & & \\
\hline 1983 & & 8 & Alicia & & 2,392 & & \\
\hline 1980 & & 8 & $\begin{array}{l}3 \text { Allen } \\
\end{array}$ & & 411 & & \\
\hline 1979 & & 9 & 9 David & & 487 & & \\
\hline 1979 & & & 7 Claudette & & 609 & & \\
\hline 1979 & & 9 & Frederic & & 3,503 & & \\
\hline 1975 & & 9 & $9 \longdiv { \text { Eloise } }$ & & 1,082 & & \\
\hline 1972 & & 6 & 6 Agnes & 122 & 6,418 & & \\
\hline 1970 & & 8 & Celia & & 1,560 & & \\
\hline 1969 & & 8 & Camille & 256 & 5,242 & & \\
\hline 1967 & & 9 & Beulah & & 844 & & \\
\hline 1965 & & 9 & Betsy & 75 & 6,461 & & \\
\hline 1964 & & 9 & 9 Dora & & 1,158 & & \\
\hline 1964 & & 10 & Hilda & 38 & 579 & & \\
\hline 1964 & & 8 & Cleo & & 595 & & \\
\hline 1961 & & 9 & \begin{tabular}{|c|} 
Carla \\
\end{tabular} & 46 & 1,927 & & \\
\hline 1960 & & 9 & Donna & 50 & 1,824 & & \\
\hline & & & & & & & \\
\hline & & & & & & & \\
\hline Damag & e incl & des all $h$ & hurricanes with dam & ge of $\$ 100,0$ & 00,000 in then-y & year do & ollars \\
\hline Dollars & have & een cor & orrected to 1990 doll & is (min becom & nes $\$ 400,000,0$ & $00)$ by & $\mathrm{NHC}$ \\
\hline Fataliti & es thr & hold fo & or this source is 25 & & & & \\
\hline
\end{tabular}




\begin{tabular}{|l|r|r|l|r|r|l|l|}
\hline \multicolumn{9}{|c|}{ TABLE 6-3: TORNADOES-ALL SOURCS EXCEPT NCDC 92 } \\
\hline Year & Rpts & Mth & Place/Name & Fatalities & $\begin{array}{l}\text { Damages } \\
\$ M\end{array}$ & $\begin{array}{l}\text { Insur } \\
\$ M\end{array}$ & References \\
\hline 1992 & & 11 & & 26 & 300 & & Friday 93 \\
\hline 1992 & & 13 & total $=1,148$ & 11 & 404 & & ACEng 93 \\
\hline 1991 & & 13 & & 651 & & ACEng 93 \\
\hline 1991 & & 13 & & 39 & 798 & & NWS 91 \\
\hline 1989 & & 13 & total $=856$ & 50 & & & Show 93 \\
\hline 1988 & & 11 & total $=121$ & 14 & 108 & & FEMA 92 \\
\hline 1988 & & 13 & total $=702$ & 29 & & & Show 93 \\
\hline 1987 & 13 & total $=656$ & 53 & & & Show 93 \\
\hline 1986 & & 13 & total $=764$ & 15 & & & Show 93 \\
\hline 1986 & 13 & & & 404 & & ACEng 93 \\
\hline 1982 & 13 & & 64 & & & CDC 89 \\
\hline
\end{tabular}




\begin{tabular}{|c|c|c|c|c|c|c|c|}
\hline \multicolumn{8}{|c|}{ TABLE 6-4: TORNADOES--NCDC 92} \\
\hline Year & Rpts & Mth & Place/Name & Fatalities & $\begin{array}{l}\text { Damages } \\
\text { \$M }\end{array}$ & $\begin{array}{l}\text { Insur } \\
\$ M\end{array}$ & References \\
\hline 1992 & & 11 & total-149 & 26 & & & \\
\hline 1990 & & 8 & total $=60$ & 29 & & & \\
\hline 1989 & & 11 & total $=58$ & 31 & & & \\
\hline 1987 & & & total $=126$ & 31 & & & \\
\hline 1985 & & & total $=182$ & 78 & & & \\
\hline 1984 & & & total $=176$ & 33 & & & \\
\hline 1984 & & & total $=73$ & 64 & & & \\
\hline 1982 & & & total $=150$ & 30 & & & \\
\hline 1979 & & & total $=120$ & 58 & & & \\
\hline 1977 & & & total $=88$ & 26 & & & \\
\hline 1974 & & & total $=194$ & 31 & & & \\
\hline 1974 & & & total $=269$ & 313 & & & \\
\hline 1973 & & & total $=250$ & 35 & & & \\
\hline 1971 & & & total $=83$ & 131 & & & \\
\hline 1970 & & & total $=88$ & 26 & & & \\
\hline 1970 & & & total $=117$ & 29 & & & \\
\hline 1969 & & & total $=3$ & 32 & & & \\
\hline 1968 & & & total $=145$ & 72 & & & \\
\hline 1968 & & & total $=102$ & 40 & & & \\
\hline 1967 & & & total $=149$ & 73 & & & \\
\hline 1966 & & & total $=12$ & 58 & & & \\
\hline 1965 & & & total $=129$ & 267 & & & \\
\hline 1960 & & & total $=201$ & 34 & & & \\
\hline & & & & & & & \\
\hline & & & & & & & \\
\hline & & & & & & & \\
\hline Data fr & om N & DC 925 & Storm Data fo & ths $1960-19$ s & 92 with fa & es 0 & 250 \\
\hline Source & does & lave dat & ta down to ze & fatalities & & & \\
\hline
\end{tabular}


TABLE 6-5: STORMS

\begin{tabular}{|c|c|c|c|c|c|c|c|}
\hline Year & Rpts & Mth & Place/Name & Fatalities & \begin{tabular}{|l} 
Damages \\
$\$ M M$
\end{tabular} & $\begin{array}{l}\text { Insur } \\
\$ M\end{array}$ & References \\
\hline 1993 & & 3 & Mid-Atlantic & 160 & 6,000 & & Friday 93 \\
\hline 1992 & & 12 & East Seaboard & 15 & 1,000 & & Friday 93 \\
\hline 1990 & & 2 & Mid-West, SE(winter) & & 300 & 140 & Berz 91 \\
\hline 1990 & & 3 & Mid-West & 12 & 200 & 100 & Berz 91 \\
\hline 1990 & & 4 & Texas(hail) & & 150 & 85 & Berz 91 \\
\hline 1990 & & 5 & $\begin{array}{l}\text { Mid-West. SE(flood } \\
\text { damage) }\end{array}$ & 19 & 200 & 50 & Berz 91 \\
\hline 1990 & & 5 & Mid-West, SE & & 200 & 100 & Berz 91 \\
\hline 1990 & & 5 & Mid-West, SE & & 300 & 150 & Berz 91 \\
\hline 1990 & & 6 & $\begin{array}{l}\text { Mid-West; SE(>100 } \\
\text { tornadoes) }\end{array}$ & 14 & 300 & 150 & Berz 91 \\
\hline 1990 & & 7 & Denver(hail) & & & 625 & Berz 91 \\
\hline 1987 & & 5 & & 29 & & & RFF 92 \\
\hline 1987 & & 12 & & 73 & & & RFF 92 \\
\hline 1985 & & 10 & & 43 & & & RFF 92 \\
\hline 1985 & & 11 & & 33 & & & RFF 92 \\
\hline 1985 & & 11 & & 49 & & & RFF 92 \\
\hline 1985 & & 5 & & 104 & & & RFF 92 \\
\hline 1984 & & 3 & & 80 & & & RFF 92 \\
\hline 1984 & & 3 & & 27 & & & RFF 92 \\
\hline 1984 & & 2 & & 29 & & & RFF 92 \\
\hline 1984 & & 2 & & 33 & & & RFF 92 \\
\hline 1983 & & 11 & & 56 & & & RFF 92 \\
\hline 1983 & & 5 & & 31 & & & RFF 92 \\
\hline 1982 & & 12 & & 34 & & & RFF 92 \\
\hline 1982 & & 4 & & 33 & & & RFF 92 \\
\hline 1982 & & 4 & & 46 & & & RFF 92 \\
\hline 1982 & & 1 & & 270 & & & RFF 92 \\
\hline 1982 & & 1 & & 37 & & & RFF 92 \\
\hline 1980 & & 3 & & 36 & & & RFF 92 \\
\hline 1980 & & 2 & & 36 & & & RFF 92 \\
\hline 1979 & & 4 & & 60 & & & RFF 92 \\
\hline 1979 & & 1 & & 100 & & & RFF 92 \\
\hline 1978 & & 3 & & 25 & & & RFF 92 \\
\hline 1978 & & 2 & & 25 & & & RFF 92 \\
\hline 1978 & & 2 & & 65 & & & RFF 92 \\
\hline 1978 & & 1 & & 100 & & & RFF 92 \\
\hline
\end{tabular}


Table 6-5 continued

\begin{tabular}{|c|c|c|c|}
\hline 1977 & 4 & 40 & RFF 92 \\
\hline 1977 & 1 & 51 & RFF 92 \\
\hline 1975 & 4 & 28 & RFF 92 \\
\hline 1975 & 1 & 50 & RFF 92 \\
\hline 1974 & 6 & 30 & RFF 92 \\
\hline 1974 & 4 & 350 & RFF 92 \\
\hline 1973 & 5 & 48 & RFF 92 \\
\hline 1973 & 4 & 26 & RFF 92 \\
\hline 1971 & 2 & 121 & RFF 92 \\
\hline 1971 & 1 & 37 & RFF 92 \\
\hline 1970 & 5 & 26 & RFF 92 \\
\hline 1969 & 7 & 41 & RFF 92 \\
\hline 1969 & 2 & 54 & RFF 92 \\
\hline 1969 & 2 & 166 & RFF 92 \\
\hline 1969 & 1 & 31 & RFF92 \\
\hline 1969 & 1 & 100 & RFF92 \\
\hline 1968 & 5 & 70 & RFF92 \\
\hline 1968 & 1 & 55 & RFF92 \\
\hline 1967 & 12 & 50 & RFF92 \\
\hline 1967 & 4 & 56 & RFF92 \\
\hline 1967 & 2 & 74 & RFF92 \\
\hline 1967 & 1 & 80 & RFF92 \\
\hline 1966 & 11 & 37 & RFF92 \\
\hline 1966 & 3 & 61 & RFF92 \\
\hline 1966 & 1 & 166 & RFF92 \\
\hline 1965 & 4 & 272 & RFF92 \\
\hline 1964 & 1 & 140 & RFF92 \\
\hline 1963 & 1 & 26 & RFF92 \\
\hline 1962 & 12 & 112 & RFF92 \\
\hline 1962 & 10 & 46 & RFF92 \\
\hline 1962 & 3 & 40 & RFF92 \\
\hline 1961 & 2 & 100 & RFF92 \\
\hline 1960 & 12 & 127 & RFF92 \\
\hline
\end{tabular}




\section{TABLE 6-6: EARTHOUAKES}

\begin{tabular}{|c|c|c|c|c|c|c|c|}
\hline Year & Rpts & Mth & Place/Name & Fatalities & $\begin{array}{l}\text { Damages } \\
\$ M\end{array}$ & $\begin{array}{l}\text { Insur } \\
\$ M\end{array}$ & References \\
\hline 1994 & & 1 & Northridge, CA & 57 & 20,000 & & Adel 94 \\
\hline 1989 & $* 1$ & 10 & & 67 & & & RFF 92 \\
\hline 1989 & $* 1$ & 10 & Loma Prieta, CA & 62 & 5,600 & & Dunbar 92 \\
\hline 1989 & $* 1$ & 10 & Loma Prieta, CA & 62 & 6,000 & & Burton 93 \\
\hline 1989 & $* 1$ & & Loma Prieta, CA & & 7,000 & & Show 93 \\
\hline 1989 & $* 1$ & 10 & Loma Prieta, CA & & 10,000 & & FEMA 92 \\
\hline 1987 & $* 2$ & 10 & Whittier, CA & 8 & 358 & & Dunbar 92 \\
\hline 1987 & $* 2$ & 10 & Whittier, CA & 9 & 350 & & CDC 89 \\
\hline 1980 & & 11 & N. Coast, CA & 5 & 3 & & Dunbar 92 \\
\hline 1980 & & 5 & Mt. St. Helens, WA & 31 & 2,000 & & Dunbar 92 \\
\hline 1971 & $* 3$ & 2 & San Fernando, CA & 65 & 900 & & CDC 89 \\
\hline 1971 & $* 3$ & $\frac{5}{2}$ & San Fernando, CA & 65 & 553 & & Dunbar 92 \\
\hline 1971 & *3 & $\overline{2}$ & & 65 & & & RFF 92 \\
\hline 1965 & $* 4$ & 4 & Seattle, WA & 7 & 13 & & Dunbar 92 \\
\hline 1965 & $* 4$ & 4 & Seattle, WA & 7 & 28 & & CDC 89 \\
\hline 1964 & $* 5$ & 3 & Alaska & 131 & 540 & & Dunbar 92 \\
\hline 1964 & $* 5$ & 3 & & 131 & & & RFF 92 \\
\hline 1964 & $* 5$ & & Alaska & & 300 & & Show 93 \\
\hline
\end{tabular}




\begin{tabular}{|c|c|c|c|c|c|c|c|}
\hline \multicolumn{8}{|c|}{ TABLE 6-7: FLOODS } \\
\hline Year & Rpts & Mth & Place/Name & Fatalities & $\begin{array}{l}\text { Damages } \\
\text { \$M }\end{array}$ & $\begin{array}{l}\text { Insur } \\
\text { \$M }\end{array}$ & References \\
\hline 1992 & & 1 & Puerto Rico & 23 & 88 & & ACEng 93 \\
\hline 1992 & & 7 & Ohio/Kentucky & 6 & 17 & & ACEng 93 \\
\hline 1992 & & 13 & total $=$ & 87 & 762 & & ACEng 93 \\
\hline 1991 & & 12 & Texas & 14 & 137 & & ACEng 93 \\
\hline 1991 & & 13 & & 46 & 1,700 & & FEMA 92 \\
\hline 1991 & & 13 & & 58 & 1,698 & & ACEng 93 \\
\hline 1990 & & 13 & & 125 & 1,636 & & ACEng 93 \\
\hline 1989 & & 13 & & 74 & 1,080 & & ACEng 93 \\
\hline 1988 & & 13 & & 37 & 225 & & ACEng 93 \\
\hline 1987 & & 13 & & 88 & 1,444 & & ACEng 93 \\
\hline 1986 & & 13 & & 208 & 6,007 & & ACEng 93 \\
\hline 1985 & & 13 & & 68 & 432 & & ACEng 93 \\
\hline 1984 & & 13 & & 104 & 3,541 & & ACEng 93 \\
\hline 1983 & & 13 & & 222 & 3,694 & & ACEng 93 \\
\hline 1978 & & 8 & & 27 & & & RFF 92 \\
\hline 1977 & & 11 & & 39 & & & RFF 92 \\
\hline 1977 & & 9 & & 26 & & & RFF 92 \\
\hline 1977 & & 7 & & 100 & & & RFF 92 \\
\hline 1976 & & 7 & & 145 & & & RFF 92 \\
\hline 1973 & & 3 & & 33 & & & RFF 92 \\
\hline 1972 & & 6 & & 237 & & & RFF 92 \\
\hline 1964 & & 12 & & 45 & & & RFF 92 \\
\hline 1964 & & 6 & & 64 & & & RFF 92 \\
\hline & & & & & & & \\
\hline & & & & & & & \\
\hline & & & & & & & \\
\hline & $13=$ & tal for $y$ & year & & & & \\
\hline & $\begin{array}{l}\text { Thres } \\
\text { is hig }\end{array}$ & Id for & Inclusion is 25 & or $\$ 100$ & damages & נnl & source \\
\hline
\end{tabular}




\subsection{The Renewal Reward Process Model Tested}

In order to test the model projections, a second series of projections were run. In this second series, the data available up to 1984 were used to project expected fatalities or damage from individual and combined natural disasters through the year 2010. The data for actual fatalities or damage were then plotted on top of the expected values to see how the model projections and the actual values for 1984 to 1994 compared. These projections are shown below for all disasters data combined and for each disaster for which there was 1960 to 1984 data. When there was 1960 data, 1959 was used as the beginning year from which to project. When there was no 1960 data, 1960 was used as the first year of the projection. Each projection was made for both an expected value $E(x)$ as well as for one standard deviation. It is of note that the actual data points tend to fall within one standard deviation of the expected or projected value for any given year. The exceptions to this involve higher than expected damage for hurricanes and earthquakes and less than expected fatalities from hurricanes. This implies that the effects of natural disasters may not be linear. In fact, one might conclude that, with better technology people are receiving warnings of oncoming events in time to leave the area at risk, so decreasing expected fatalities. In parallel, the increasing development and density of construction, especially in risk-prone areas, may increase the potential economic losses from natural disasters. Several sources have suggested that these trends are true in the developed world. In conclusion, the figures below show that the expected and actual results tend to be consistent and suggest that the model is a reasonable, if lower bound for damage and upper bound for fatalities, method of projecting the effects of natural disasters. 


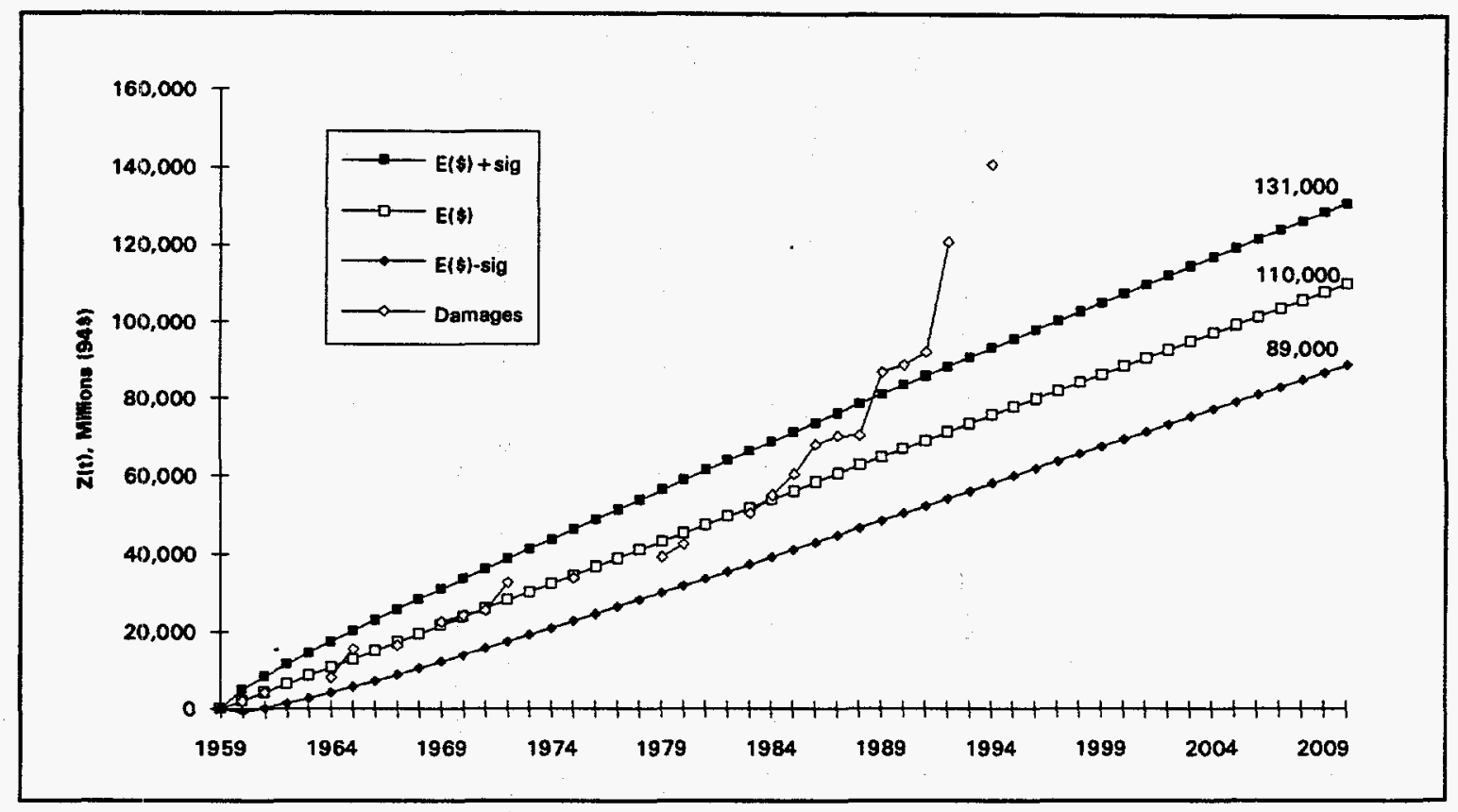

Figure 7-1. Projected and Actual Cumulative Damage from All Disasters

(Actual data available for 1960 to 1984 used for projected damage)

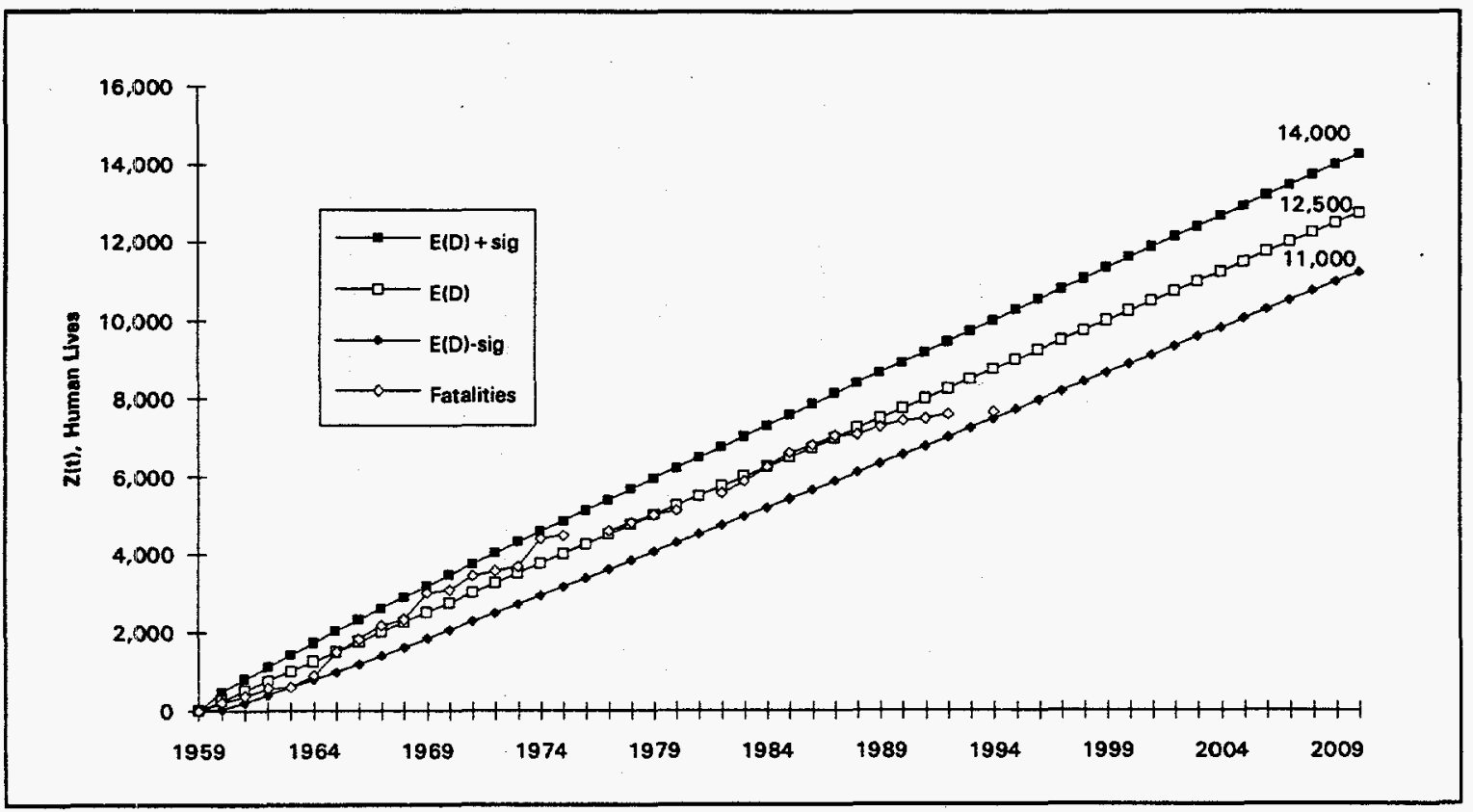

Figure 7-2. Projected and Actual Cumulative Fatalities from All Disasters (Actual data available for 1960 to 1984 used for projecting fatalities) 


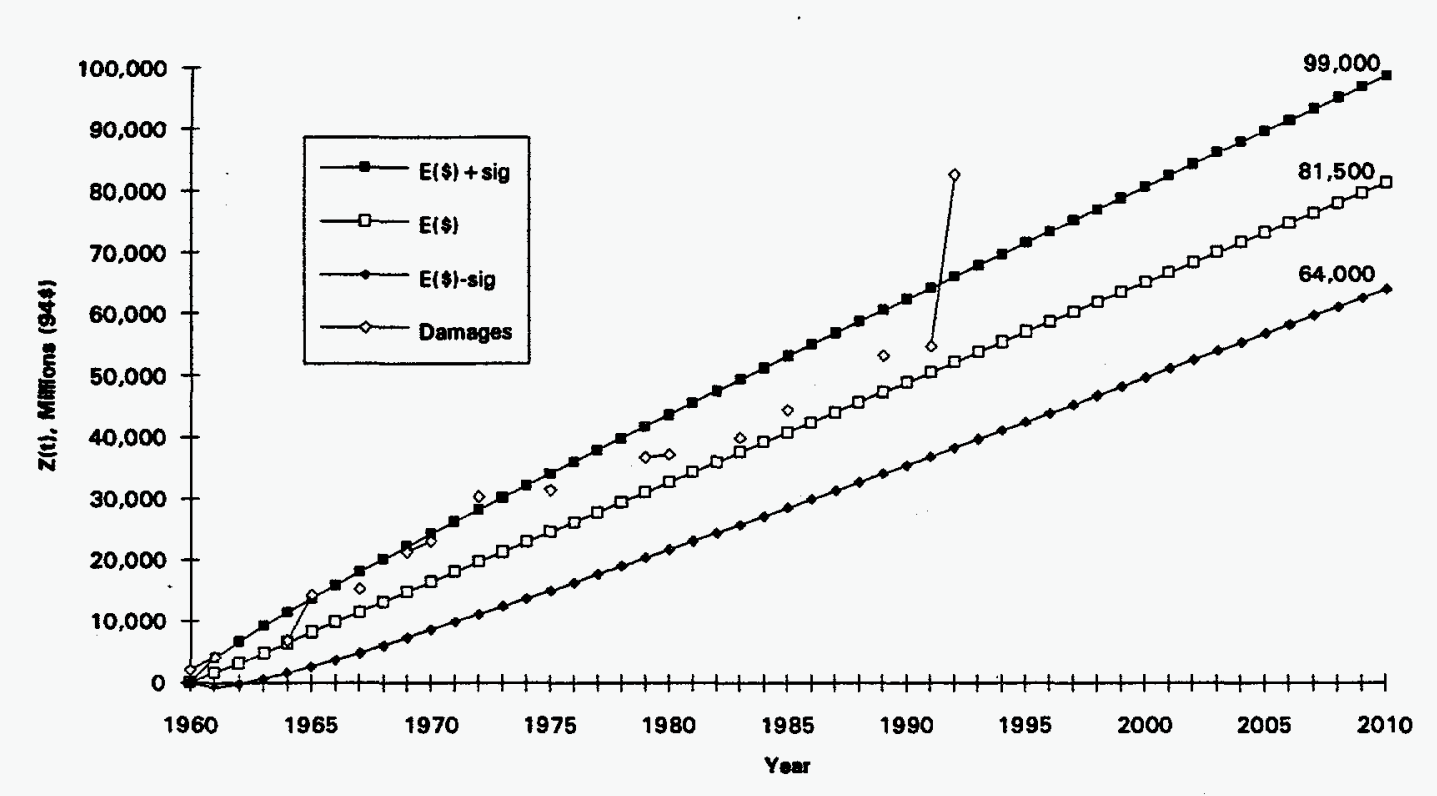

Figure 7-3. Projected and Actual Cumulative Damage from Hurricanes (Actual data available for 1960 to 1984 used for projected damage)

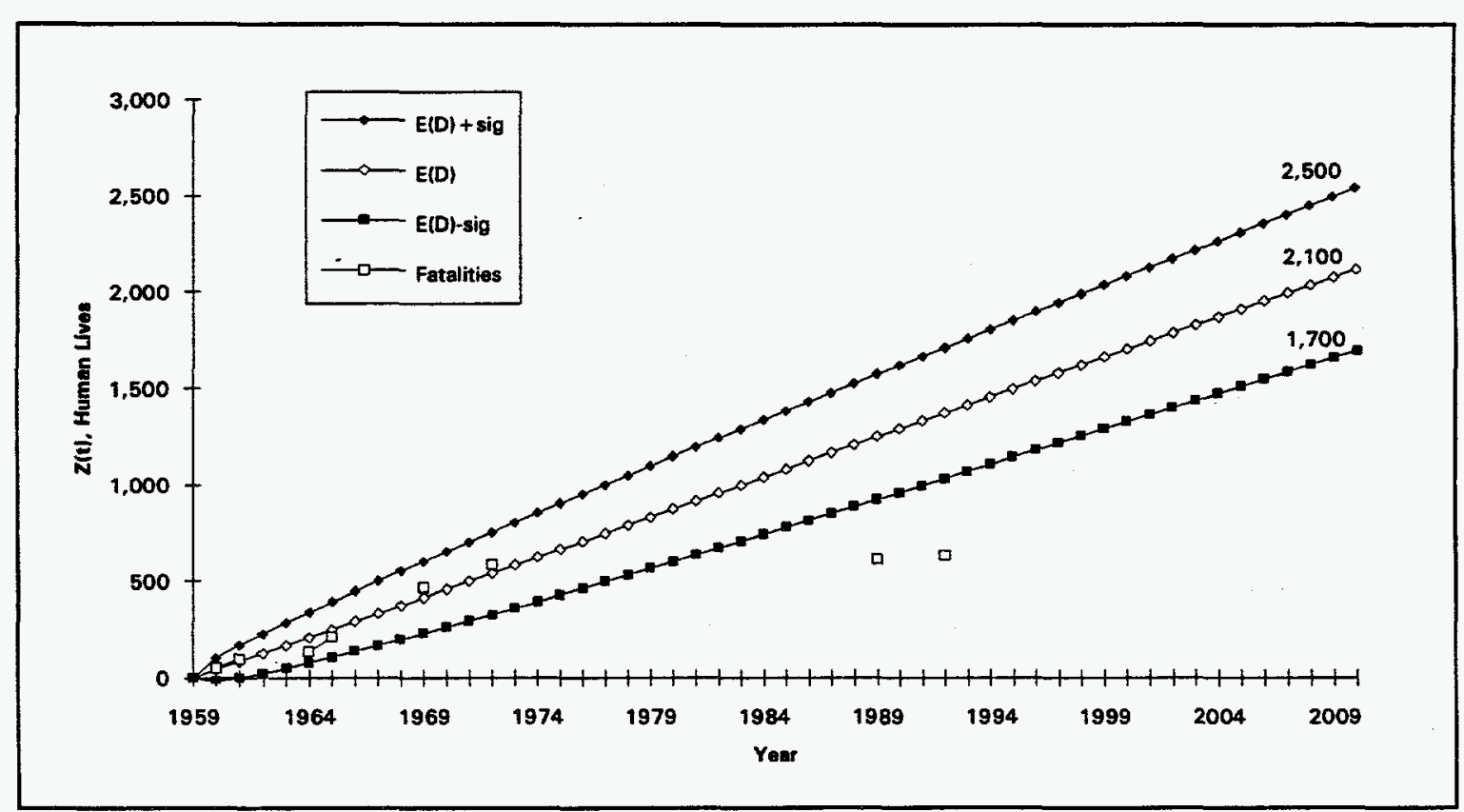

Figure 7-4. Projected and Actual Cumulative Fatalities from Hurricanes (Actual data available for 1960 to 1984 used for projected fatalities) 


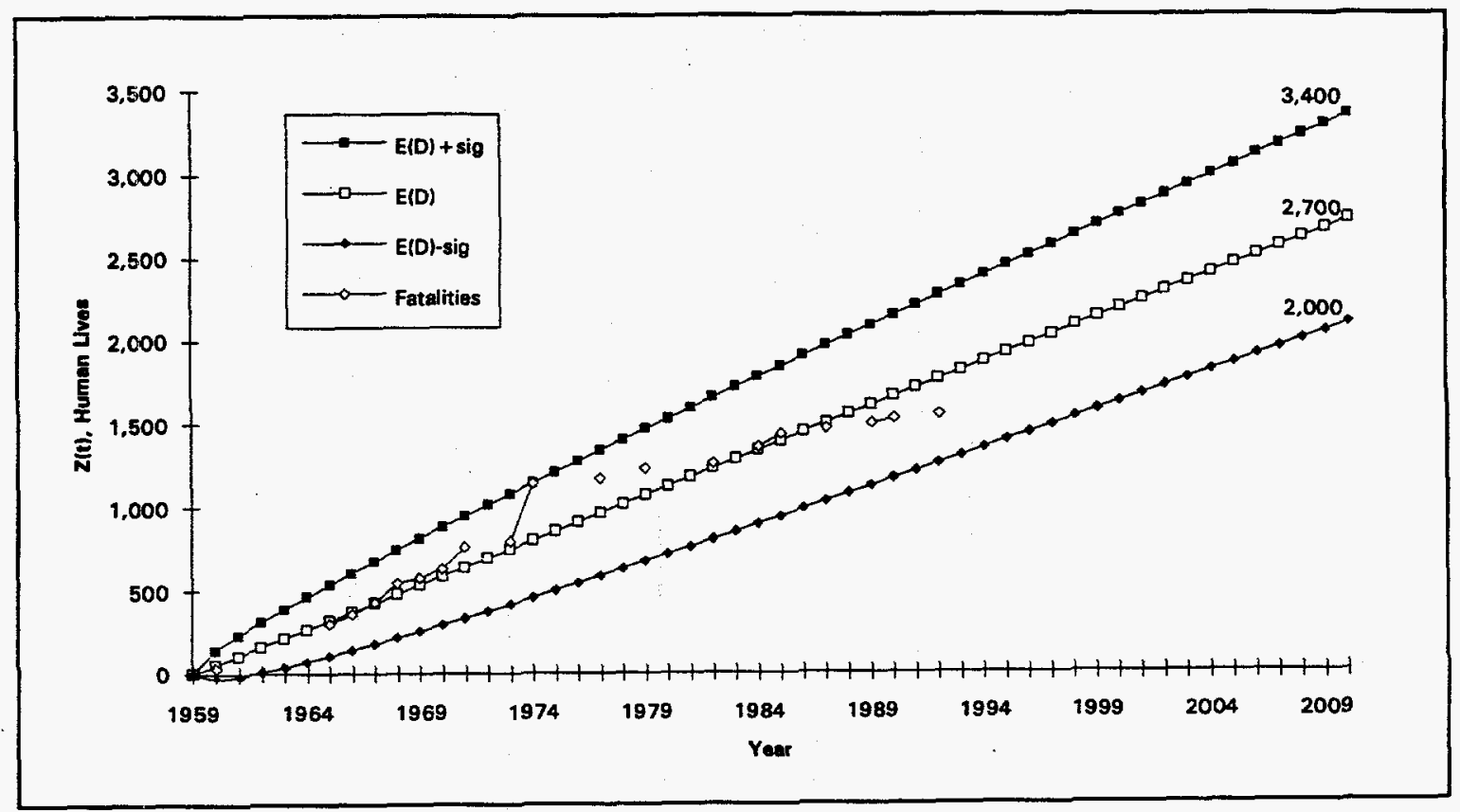

Figure 7-5. Projected and Actual Cumulative Fatalities from Tornadoes (Actual data available for 1960 to 1984 used for projected fatalities)

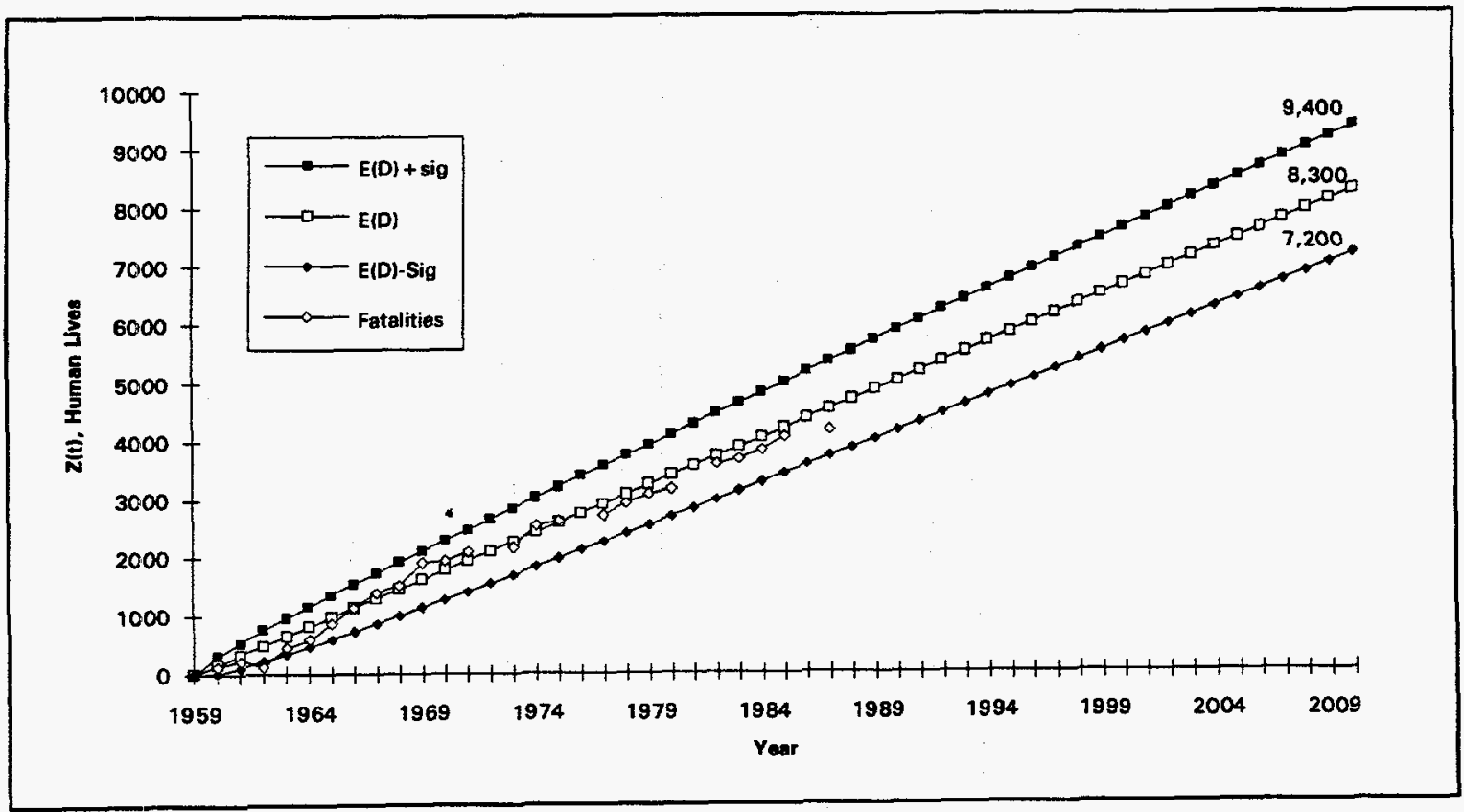

Figure 7-6. Projected and Actual Cumulative Fatalities from Storms (Actual data available for 1960 to 1984 used for projected fatalities) 


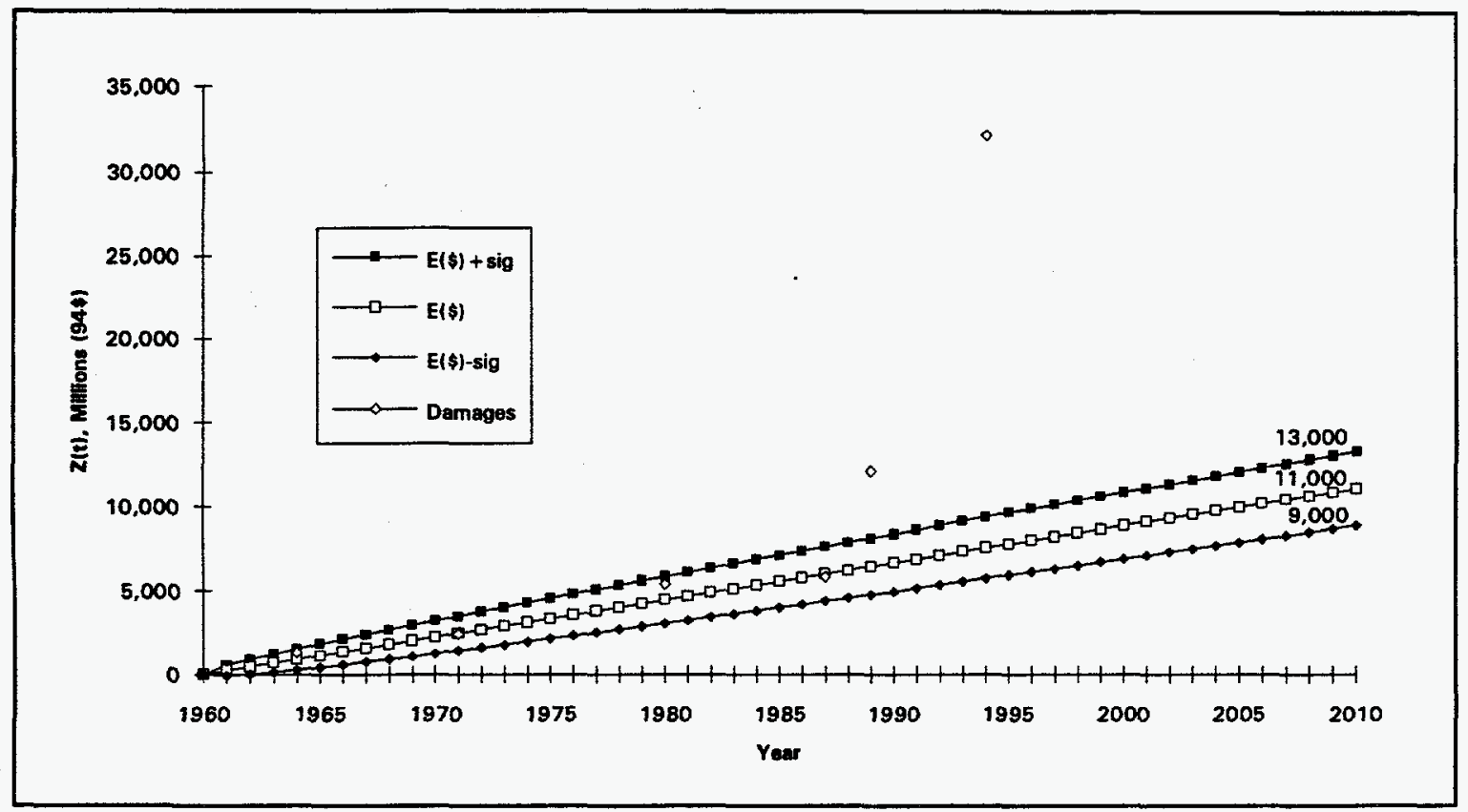

Figure 7-7. Projected and Actual Cumulative Damage from Earthquakes (Actual data available for 1960 to 1984 used for projected damage)

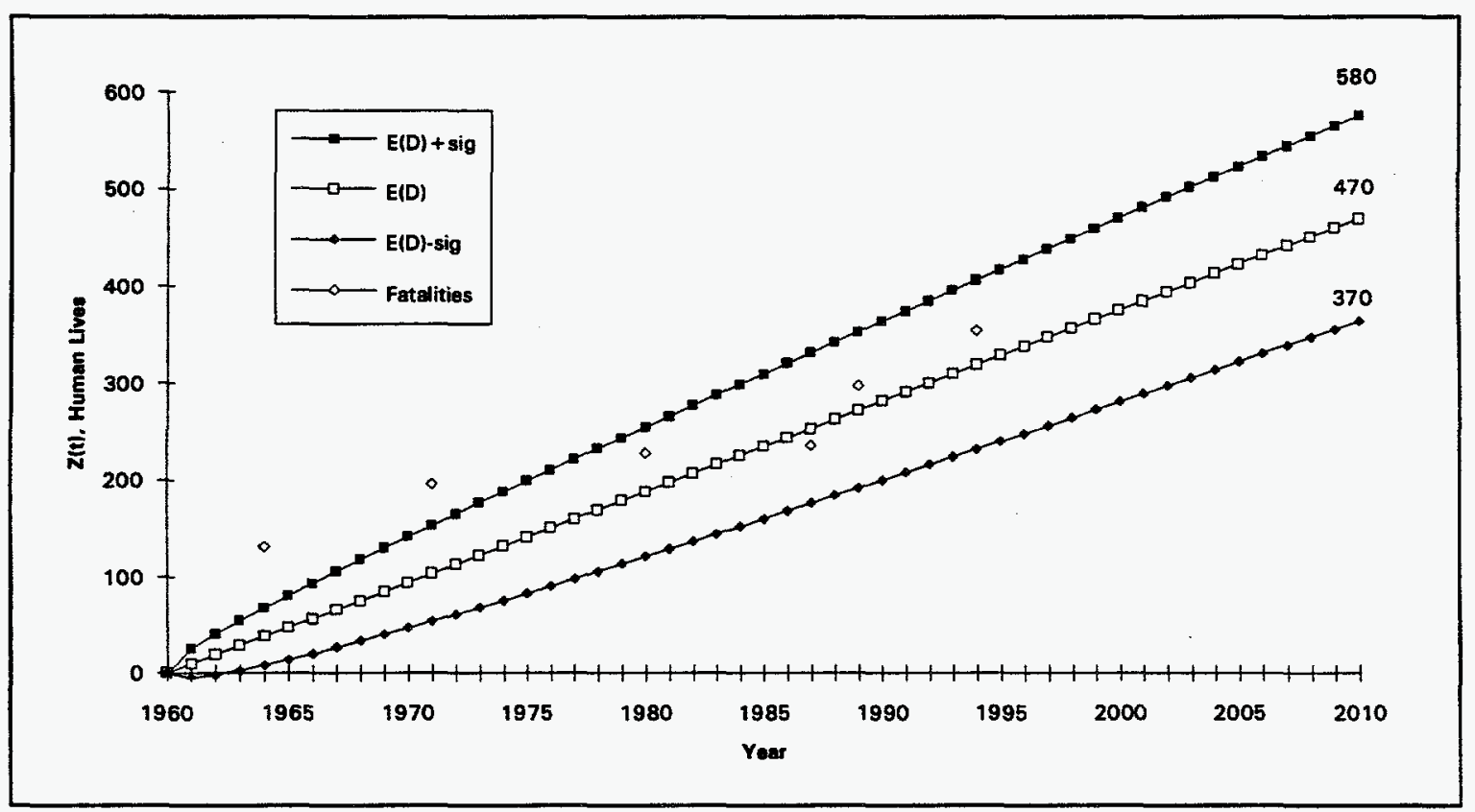

Figure 7-8. Projected and Actual Cumulative Fatalities from Earthquakes (Actual data available for 1960 to 1984 used for projected fatalities) 


\subsection{Bibliography}

\subsection{References}

Adelman, P.E., 1994, Statement before the U.S. House of Representatives Committee on Science, Space, and Technology; Hearings on lessons learned from the Northridge Earthquake. Washington, D.C., March 2, 1994.

Berz, G., 1992, "Losses in the range of U.S. $\$ 50$ billion and 50,000 people killed: Munich Re's list of major natural disasters in 1990." In Natural Hazards Vol. 5, 1992, pp. 95-102.

Burton, Ian, Robert W. Kates, and Gilbert F. White, 1993; The Environment as Hazard. 2nd ed. Guilford Press, New York and London.

Centers for Disease Control and Prevention (CDC), 1989, The Public Health Consequences of Disasters, 1989. Public Health Service, U.S. Department of Health and Human Services, September 1989.

Changnon, Stanley A. and Joyce M., 1992, "Storm Catastrophes in the United States." In Natural Hazards Vol. 6, No. 2, 1992, pp. 93-107.

Clark, Charles S., 1993, 'Disaster Response: Does the Country Need a New National Strategy?" CQ Researcher, October 15, 1993.

Degg, Martin, 1992, "Natural Disasters: Recent Trends and Future Prospects." In Geography, Vol. 77, No. 336, July 1, 1992, pp 198-209.

Dunbar, Paula; Patricia Lockridge, and Lowell Whiteside, 1992, Catalogue of Significant Earthquakes 2150 BC to 1991 Including Quantitative Casualties and Damage. National Geophysical Data Center, Boulder, Colorado.

Federal Emergency Management Agency (FEMA), 1994, Database showing demands on the disaster relief fund (DRF) between October 1, 1988 and March 30, 1994.

FEMA, 1992, Principal Threats Facing Communities and Local Emergency Management Coordinators. FEMA-191, April 1992.

FEMA, 1990, Risks and Hazards: A State by State Guide. FEMA-196, September 1990.

Friday, Elbert W. Jr., 1993, Written testimony before the U.S. House of Representatives Subcommittee on Space; Committee on Science, Space, and Technology. Washington, D.C., September 14, 1993. 
Glickman, Theodore S., and Karen S. Terry, 1994, Using the News to Develop a Worldwide Database of Hazardous Events. Final report on NSF Research Grant No. SBR-9309369. Center for Risk Management, Resources for the Future, Washington, D.C, August 1994.

Glickman, Theodore S., Dominic Golding, and Emily D. Silverman, 1992, Acts of God and Acts of Man. Discussion Paper CRM 92-02. Center for Risk Management, Resources for the Future, Washington, D.C., May 1992.

Natural Hazards Research and Applications Information Center, 1990, The Natural Hazards Data Resources Directory. NHRAIC Special Publication No. 21. University of Colorado.

National Climatic Data Center (NCDC), 1992, NOAA, National Environmental Satellite, Data, and Information Service, Storm Data, Vol. 34, No. 12, 1992.

National Hurricane Center, 1993, The Deadliest, Costliest, and Most Intense United States Hurricanes of this Century (and Other Frequently Requested Hurricane Facts), National Weather Service, NOAA Technical memorandum NWS NHC-31. Updated February 1993.

National Weather Service, 1991, A Summary of Natural Hazard Deaths for 1991 in the United States. Warning and Forecast Branch.

Showalter, Pamela, William Riebsame, and Mary Fran Myers, 1993, Natural Hazard Trends in the United States: A Preliminary Review for the 1990s. NHRAIC Working Paper 83, University of Colorado, February 1993.

Thompson, Stephen A., 1982, Trends and Developments in Global Natural Disasters, 1947-1981, NHRAIC Working Paper 45. University of Colorado, August 1982.

U.S. Army Corps of Engineers (ACEng), 1992, U.S. Army Corps of Engineers Anmual Flood Damage Report to Congress for Fiscal Year 1992. February 1993. 


\subsection{Additional Resources}

Alexander, David. Natural Disasters. UCLA Press, London and New York, 1993.

Bras, Rafael. The World at Risk: Natural Hazards and Climate Change. American Institute of Physics, 1993. (AIP conference proceedings, includes information on hazardous geographic environments, climatic changes, natural disasters-planning.)

Coburn, Andrew and Robin Stence. Earthquake Protection. John Wiley and Sons, 1992.

Federal Emergency Management Agency. Justification of Estimates Fiscal Year 1995. Salaries and Expenses, Emergency Management Planning and Assistance, Disaster Relief Fund, Office of the Inspector General, Emergency Food and Shelter, National Insurance Development Fund, National Flood Insurance Fund. Submitted to Congress February 1994.

Harris, Stephen L. Agents of Chaos: Earthquakes, Volcanoes, and Other Natural Disasters. Missoula, Montana: Mountain Press Publishing Co., 1990.

Office of United Nations Disaster Relief Coordinator. Mitigating Natural Disasters: Phenomena, Effects and Options; a Mamual for Policy Makers and Planners. New York, 1991.

Palm, Risa. Natural Hazards: An Integrative Framework for Research and Planning. Baltimore: Johns Hopkins University Press, 1990.

Robinson, Andrew. Earth Shock: Hurricanes, Volcanoes, Earthquakes, Tornadoes and Other Forces of Nature. New York: Thames and Hudson, 1993.

Smith, Keith. Environmental Hazards: Assessing Risk and Reducing Disaster. London and New York: Routledge, 1992.

U.S. General Accounting Office. Foreign Disaster Assistance. AID Has Been Responsive but Improvements Can Be Made, GAO/NSIAD-93-21. Report to the U.S. House of Representatives Subcommittee Chairman, Legislation and National Security, Committee on Government Operations. Washington, D.C., October 1992.

\footnotetext{
Weather Forecasting. Systems Architecture Needed for National Weather Service Modernization, GAO/AIMD-94-28. Report to Congressional Requesters. Washington, D.C., March 1994.

Disaster Relief Fund. Actions Still Needed to Prevent Recurrence of Funding Shortfall, GAO/RCED-93-60. Report to the U.S. House of Representatives Subcommittee on Investigations and Oversight, Committee on Public Works, and Transportation. Washington, D.C., February 1993.
} 
- Disaster Management. Improving the Nation's Response to Catastrophic Disaster, GAO/RCED-93-186. Report to Congressional Requesters. Washington, D.C., July 1993.

\section{Copyright Permissions}

The following information/figures have been reprinted with permission from the publishers:

Table 3-1: The information in Table 3-1 is reprinted by permission of The Natural Hazards Research and Applications Information Center.

Table 3-2: The information in Table 3-2 is reprinted by permission of The Center for Risk Management of the Resources for the Future.

Table 3-3: The information in Table 3-3 is reprinted by permission of Kluwer Academic Publishers.

Figure 3-1: Figure 3-1 is reprinted by permission of The Guilford Press. 


\subsection{Legislative Activity}

U.S. Senate Committee on Agriculture, Nutrition, and Forestry. The Scope and Components of Federal Disaster Relief in the Flood-Ravaged Midwest: Hearing before the Committee on Agriculture, Nutrition, and Forestry. 103d Congress, July 16, 1993.

U.S. House Committee on Science, Space, and Technology. NOAA's Response to Weather Hazards - Has Nature Gone Mad? Hearing before the Subcommittee on Space. 103d Congress, September 14, 1993.

Hearing on Lessons Learned from the Northridge, Earthquake. Statement of Andrew A. Adelman,.P.E. "An Overview of the Effectiveness of Design and Construction Practices and Building Codes in the Northridge Earthquake of January 17, 1994." Washington, D.C., March 2, 1994.

- Statement of George E. Brown, Jr., committee chairman.

- Statement of Guy Nordenson, JP.

—. Statement of Ronald L. Mayes, President, Dynamic Isolation Systems, Inc.

- Statement of L. Thomas Tobin,. Executive Director, Seismic Safety Commission, State of California.

—. Statement of Lucille M Jones, Ph.D., Geophysicist, U.S. Geological Survey.

- Statement of John F. Hall.

. Statement of Thomas H. Heaton, Geophysicist, U.S. Geological Survey.

. Statement of Kaye M. Shedlock.

\section{BILLS}

H.R. 2873

To amend the Robert T. Stafford Disaster Relief and Emergency Assistance Act to provide for an expanded Federal program of hazard mitigation, relief, and insurance against the risk of catastrophic natural disasters, such as hurricanes, earthquakes, and volcanic eruptions, and for other purposes.

\section{S. 1350}

To amend the Earthquake Hazards Reduction Act of 1977 to provide for an expanded Federal program of hazard mitigation and insurance against the risk of catastrophic natural disasters, such as hurricanes, earthquakes, and volcanic eruptions, and for other purposes. 


\section{S. 995}

To improve the ability of the Federal Government to prepare for the respond to major disasters, and for other purposes.

S. 1697

To improve the ability of the Federal Government to prepare for the respond to major disasters, and for other purposes.

H.R. 2548

To improve the ability of the Federal Government to prepare for the respond to major disasters, and for other purposes.

H.R. 3399

To improve the ability of the Federal Government to prepare for the respond to major disasters, and for other purposes.

H.R. 3295

To improve the ability of the Federal Government to prepare for the respond to major disasters, and for other purposes. 


\section{DISTRIBUTION:}

1 James J. Solberg

Purdue University

Center for Collaborative Manufacturing

Potter Room 114

West Lafayette, IN 47907-1291

8 Katherine Clark

Tech Reps, Inc.

5000 Marble Ave. NE

Albuquerque, NM 87110

$\begin{array}{ccl}1 & \text { MS0722 } & \text { Jessica Glicken, 6912 } \\ 1 & \text { MS0722 } & \text { Ken Washington, 6913 } \\ 1 & \text { MS0722 } & \text { Deborah Frank-Brown, 6912 } \\ 1 & \text { MS0722 } & \text { Steve Kleban, 6913 } \\ 1 & \text { MS0724 } & \text { Dan Hartley, 6000 } \\ 1 & \text { MS0725 } & \text { Tom Hunter, 6900 } \\ 1 & \text { MS0725 } & \text { Gil Cano, 6909 } \\ 1 & \text { MS0743 } & \text { 6907 File } \\ 20 & \text { MS0743 } & \text { Dennis Engi, 6907 } \\ 1 & \text { MS0768 } & \text { John Kane, 5806 } \\ 1 & \text { MS0769 } & \text { Dennis Miyoshi, 5800 } \\ 1 & \text { MS1393 } & \text { Steve Binkley, 6908 } \\ & & \\ 1 & \text { MS9018 } & \text { CTF, 8523-2 } \\ 5 & \text { MS0899 } & \text { Technical Library, 13414 } \\ 1 & \text { MS0619 } & \text { Print Media, 12615 } \\ 2 & \text { MS0100 } & \text { Document Processing, 7613-2 } \\ & & \text { For DOE/OSTI }\end{array}$

